BIOMED

QL

684

FG

1919 당

A $\overline{\text { A }}$ 辜

0 王

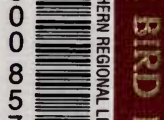

7 衰要

3 衰表?

4

5

है

Q

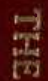

$\frac{9}{20}$ 
THE GIFT OF

FLORENCE V. V. DICKEY

TO THE

UNIVERSITY OF CALIFORNIA

AT LOS ANGELES
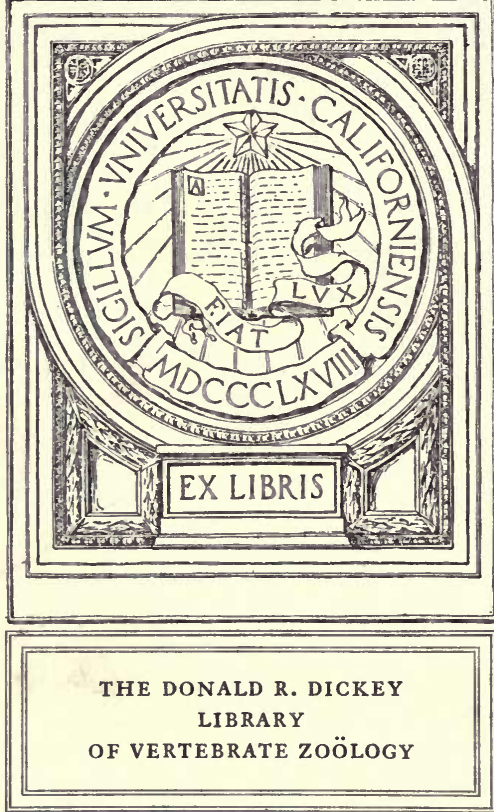


\section{THE BIRD ROOKERIES OF THE TORTUGAS}

BY

PAUL BARTSCH

Curator, Marine Invertebrates, U. S. National Museum

FROM THE SMITHSONIAN REPORT FOR 1917, PAGES 469-500 (WITH 38 PLATES)

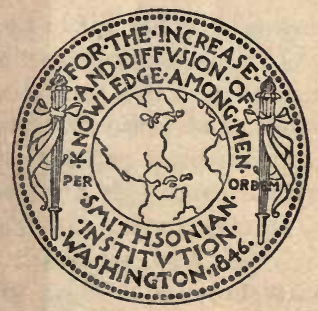

(Pubuication 2512)

WASHINGTON

GOVERNMENT PRINTING OFFICE 



\section{THE BIRD ROOKERIES OF THE TORTUGAS.}

By Paul Bartsch,

Curator, Marine Invertebrates, U. S. National Museum.

[With 38 plates.]

Look at a map of the southeastern United States and you will note a string of islands swinging south, then bending more and more westward at some little distance off the peninsula of southern Florida. These are the Florida Keys, a part of which in reality represents an ancient barrier reef long since elevated above the surface of the sea. Some of these keys are mere barren sand banks, while others are clothed with tropical vegetation. Quite a number of these islands have recently been joined by the fills and viaducts of the over-sea portion of the Florida East Coast Railway which connects Key West with the mainland, and promises to produce profound changes in the topography of the region. This chain of keys terminates in the Tortugas Atoll, the scene of our story, some 65 statute miles west of Key West.

The elevated portions of the atoll at present are East, Middle, and Sand Key, of the middle eastern perimeter; Long, Bush, Bird, Garden Key of the southwestern rim; and Loggerhead Key on the southwestern border. Formerly two other keys, Northeast Key and North Key, of the northeastern edge, were conspicuous elevated elements above the sea's surface, but they have long since been swept away by the waves. Of the existing keys, Middle and Sand Key are mere heaps of piled up sea organisms and their fragments, without vegetation. Bush Key now appears as an elevated coral reef with piles of organic detritus heaped up in spots, but likewise barren of regetation. East Key supports a dense growth of Bermuda grass on the flattened, upper elevated portion, with a scattered growth of scaevola bushes and other plants. A somewhat similar condition obtains on the southern end of Long Key, but the vegetation is less abundant and more scattered, while the northern end consists of a barren rim of coral boulders that curves eastward and southward, to join with the reef fringe of Bush Key. Garden Key is almost completely inclosed by the walls of Fort Jefferson. The portion outside of the wall is overgrown with crab grass and the long trailing vines of the 
sea bean and the moon vine and the goat-foot morning-glory, while within the wall several species of palms and a grove of buttonwood, Cordia trees and ornamental shrubs furnish a favorite retreat to the many lesser migratory birds. Bird Key has an almost dead fringe of bay cedars and a few coconut palms near the house and a scattered, scant growth of cactus and grass, as well as a few ornamental shrubs near the buildings. The largest of the keys is Loggerhead Key, the center of which is occupied by Loggerhead Light, a first-class, revolving, flashing beacon that projects a beam for more than 18 miles, and the buildings necessary to quarter the attendants. On the west central portion is a boat shed and pier, while the east central portion is provided with another pier and landing stage. On the northern end of the island the buildings of the Marine Biological Iaboratory of the Carnegie Institution are nestled in a growth of palms, maritime pines, and flowering shrubs, fringed on the sea side by bay cedars, Tournefortias, and Bermuda grass. Excepting the introduced palms, figs and other ornamental plants about the laboratory and the light, the most conspicuous vegetal features of the island are the bay cedars, which practically girdle, and in many places completely cross it. These attain a height of more than 10 feet. This corering of bay cedars is irregularly interrupted by grassy meadows, where the short crab grass and spear grass vie with the flat-leaved cactus for supremacy. The scattered huge agaves south of the lighthouse usually rear some flowering stalks, which furnish a favorite resting place for the hawks during the migratory season. A Cordia grove occupies the east shore line a little north of the light, and here and there groups of ashy leared Tournefortias lend a funereal aspect to the beach. In places, dense growths of Bermuda grass occur immediately above the reach of the storm tide and wave their abundant, shimmering heads of seeds in a most pleasing manner. In other regions, similar reaches are covered by a fuzzy, brown-topped sedge, while still other places are measured by the long trailing vines of the goat-foot morning-glory (Ipomaea pes-caprae), the moon vine Calonyetion $t u b a$ ), and the sea bean (Canavali lineata).

The most interesting island of the group is Bird Key, for of the 32,810 birds listed for the group in last summer's census, 31,200 center about this key. In the list given below the numbers in italic refer to Bird Key inhabitants.

A numerical list of the summer birds of the Tortugas.

(Based upon observations made between July 19-31, 1917.)

Laughing gull

Royal tern

Roseate tern. estimated_-- $\begin{aligned} & \text { adult } \\ & \text { young }\end{aligned}$ 


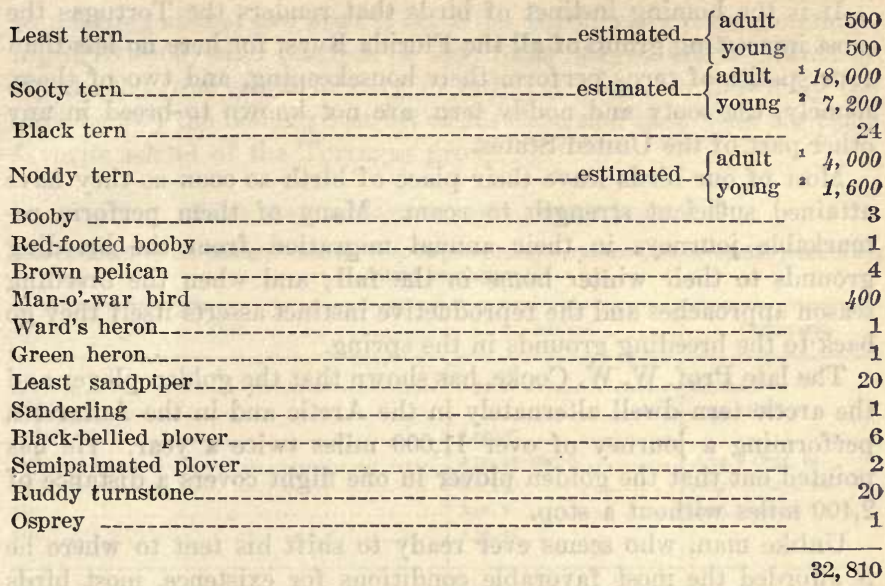

These rookeries were first brought to the attention of ornithologists by John James Audubon, who, in his masterful ornithological biographies, gives us an account of a visit to these keys in May, 1832. W. E. D. Scott, in his paper "On birds observed at the Dry Tortugas, Florida, during parts of March and April, 1890," ${ }^{3}$ gives us the first list of birds noted in the group, while Dr. Joseph Thompson, United States Navy, in 1903 described "The Tortugas tern colony" in the fifth volume of Bird Lore."

It is safe to state that the most intensive scrutiny to which a wild bird colony has been subjected was made upon the birds of Bird Key by Dr. John B. Watson, professor of experimental and comparative psychology at the Johns Hopkins University, and Dr. K. S. Lashley, while a Johnston scholar in psychology at the same institution. These gentlemen subjected the terns to exhaustive psychoanalyses with the hope of throwing light on the problem of the homing instinct. In getting at the basic data underlying this problem they found it necessary to study the various phases of the activities displayed by the birds in and about the island. The results of their splendid efforts are embodied in a series of papers from which $I$ shall take the liberty to quote at some length. ${ }^{5}$ e

\footnotetext{
1 Based upon Doctor Watson's census of 1908.

An estimate admitting two-fifths as many offspring as we had parents.

The Auk, vol. 7, pp. 301-314.

4 Bird Lore, vol. 5, pp. 73-84.

" "The Behavior of Noddy and Sooty Terns," John B. Watson, Papers from the Tortugas Laboratory of the Carnegie Institution of Washington, vol. 2, No. 103, 1908, pp. 189-255.

" Homing and Related Activities of Birds," papers from the Dept. of Marlne Blology of the Carnegie Institution of Washington, vol. 7, No. 211.
} 
It is the homing instinct of birds that renders the Tortugas the most interesting group of all the Florida Keys, for here no less than four species of terns perform their housekeeping, and two of these, namely, the sooty and noddy tern, are not known to breed in any other part of the United States.

Most of our birds leave their place of birth as soon as they have attained sufficient strength to roam. Many of them perform remarkable journeys in their annual migration from the breeding grounds to their winter home in the fall; and when the breeding season approaches and the reproductive instinct asserts itself they go back to the breeding grounds in the spring.

The late Prof. W. W. Cooke, has shown that the golden plover and the arctic tern dwell alternately in the Arctic and in the Antarctic, performing a journey of over 11,000 miles twice a year. $\mathrm{He}$ has pointed out that the golden plover in one flight covers a distance of 2,400 miles without a stop.

Unlike man, who seems ever ready to shift his tent to where he is afforded the most favorable conditions for existence, most birds cling tenaciously to the immediate surroundings in which they were cradled when it comes to a selection of a nesting site.

This fact was first demonstrated by sea birds known to breed on certain islands, and on these only. More recently it has also been shown that many of the lesser birds cling equally persistently to their nesting site and it has been found that some not only seek the same general region, but the same shelf of rocks and even the same nest year after year.

Look at a good hydrographic chart (pl. 1) and you will note that the Tortugas, though situated on the shallow continental shelf, are on the extreme outer limit thereof, away out in the Gulf of Mexico, removed from the murky waters of the southward drift that constitutes the coastal waters of the peninsula, and in a little less degree that bathing the upper keys. Here we have the clear water of the Gulf Stream and the first clear water shallows available for a spawning ground to the fishes of the Gulf. The presence of an enormous number of small fish fry at the proper season was, probably more than any other factor, the determining cause in the selection of this site for the rookery by the ancestors of the enormous tern colonies that breed here. It is also quite possible that the factor determining the time of arrival and departure of the birds may depend upon the migration and spawning season of the fish used by these birds as food.

When not on the breeding grounds, the noddy and sooty terns roam in small groups over the waters to the south of our islands. I have met them on both coasts of Cuba and Haiti, where they can be 
seen fishing as they are wont to do in the Tortugas, or resting on floating driftwood, sand beaches, or low, rocky ledges, but in March or April (the time seems to wary in different years, as shown by the table below) the homing instinct seizes them and they head for their favorite island of the Tortugas group.

Table showing dates of arrival and departure.

Data furnished by the Biological Survey, U. S. Department of Agriculture, whose warden protects the colony from eggers.)

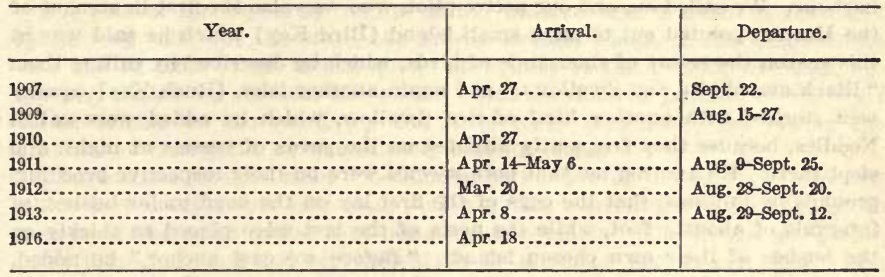

Watson and Lashley, in speaking of the Bird Key rookery, 1915, page 61 , say:

The terns breed in great numbers upon Bird Key. * * * Their nests, of which there were more than 10,000 in 1908 , are in many cases closely crowded together, as many as 30 sooty nests being found in an area of 100 square feet, and the nests and eggs are almost indistinguishable to the human observer. Indeed, the island suggests a city of 10,000 houses, all much alike, unnumbered, and set down at random, without streets or definite landmarks. The birds choose their own nests, without error, from among hundreds of similar ones, and under normal conditions never show the slightest hesitation in making their choice.

I will now consider, one by one, the various species in the order of their numerical representation. I shall use freely the data furnished by Audubon. Watson, and Lashley in the discussion of the various forms.

\section{THE SOOTY TERN (Onychoprion fuscatus).}

By far the largest number of breeding birds on the Tortugas belong to this species, of which probably more than 25,000 are present on Bird Key at the close of the breeding season.

Our earliest record of this colony was furnished by that master of ornithological biography, John James Audubon. ${ }^{1}$ The description which he gives us of the colony, based upon a visit during the early part of the last century, is extremely interesting. The rareness and inaccessibility of the volume demands a full quotation in order that an adequate comparison may be had with the now existing conditions. We therefore quote the following:

Early in the afternoon of the 9th of May, 1832, I was standing on the deck of the United States revenue-cutter the Marion. The weather was very beautiful, 
although hot, and a favourable breeze wafted us onwards in our course. Captaín Robert Day, who stood near me, on looking toward the south-west, ordered some person to be sent to the top to watch the appearance of land. A young lad was instantly seen ascending the rigging, and not many minutes after he had attained his post, we heard from him the cry of "land." It was the low keys of the Tortugas, toward which we had been steering. No change was made in the course of the "Lady of the Green Mantle," who glided along as if aware of the knowledge possessed by her commander. Now the light-house lantern appeared like a bright gem glittering in the rays of the sun. Presently the masts and flags of several wreckers showed us that they were anchored in the small but safe harbour. We sailed on, and our active pilot, who was also the first lieutenant of the Marion, pointed out to me a small island [Bird Key] which he said was at this season the resort of thousands of birds, which he described by calling them "Black and White Sex Swallows," and again another islet, [Bush Key] equally well stocked with another kind of Sea Swallow, which he added were called Noddies, because they frequently alighted on the yards of vessels at night, and slept there. He assured me that both species were on their respective breedinggrounds by millions, that the eggs of the first lay on the sand under bushes, at intervals of about a foot, while the nests of the last were placed as thickly on the bushes of their own chosen island. "Before we cast anchor," he added, "you will see them rise in swarms like those of bees when disturbed in their hive, and their cries will deafen you."

You may easily imagine how anxious I was to realize the picture; I expressed a wish to be landed on the island; but the kind officer replied, "MIy good Sir, you will soon be tired of their incessant noise and numbers, and will enjoy the procuring of Boobies much better." After various tacks, we made our way through the curious and extremely dangerous channels leading to the small harbour, where we anchored. As the chain grated the ear, I saw a cloud-like mass arise over the "Bird Key" from which we were only a few hundred yards distant; and in a few minutes the yawl was carrying myself and my assistant ashore. On landing, I felt for a moment as if the birds would raise me from the ground, so thick were they all round, and so quick the motion of their wings. Their cries were indeed deafening, yet not more than half of them took to wing on our arrival, those which rose being chiefly male birds, as we afterwards ascertained. We ran across the naked beach, and as we entered, the thick cover before us, and spread in different directions, we might at every step have caught a sitting bird, or one scrambling through the bushes to escape from us. Some of the sallors, who had more than once been there before, had provided themselves with sticks, with which they knocked down the birds as they flew thick around and over them. In less than half an hour, more than a hundred Terns lay dead in a heap, and a number of baskets were filled to the brim with eggs. We then returned on board, and declined disturbing the rest any more that night. My assistant, Mr. H. Ward, of London, skinned upward of fifty speclmens, aided by Captain Day's servant. The sailors told me that the birds were excellent eating, but on this point I cannot say much in corroboration of their opinion, although I can safely recommend the eggs, for I considered them delicious, in whatever way cooked, and during our stay at the Tortugas we never passed a day without providing ourselves with a good quantity of them.

The next morning Mr. Ward told me that great numbers of the Terns left their island at two o'clock, flew off towards the sea, and returned a little before day, or about four o'clock. This I afterwards observed to be regularly the case, unless there happened to blow a gale, a proof that this species sees as well during the night as by day, when they also go to sea in search of food 
for themselves and their young. In this respect they differ from the Sterna stolida, which, when overtaken at sea by darkness, even when land is only a few miles distant, alight on the water, and frequently on the yards of vessels, where if undisturbed they sleep until the return of day. It is from this circumstance that they have obtained the name of Noddy, to which in fact they are much better entitled than the present species, which has also been so named, but of which I never observed any to alight on a vessel in which I was for thirty-five days in the Gulf of Mexico, at a time when that bird was as abundant during the day as the other species, of which many were caught at my desire by the sailors.

The present species rarely alights on the water, where it seems incommoded by its long tail; but the other, the Sterna stolida, which, in the shape of its tail, and in some of its habits, shows an affinity to the Petrels, not only frequently alights on the sea, but swims about on floating patches of the Gulf Weed, seizing on the small fry and little crabs that are found among the branches of that plant, or immediately beneath them.

I have often thought, since I became acquainted with the habits of the bird which here occupies our attention, that it differs materially from all the other species of the same genus that occur on our coasts. The Sterna fuliginosa never dives headlong and perpendicularly as the small species are wont to do, such as St. hirundo, St. arctica, St. minuta, St. Dougallii, or St. nigra, but passes over its prey in a curved line, and picks it up. Its action I cannot better compare to that of any other bird than the Night Hawk, while plunging over its female. I have often observed this Tern follow and hover in the wake of a porpoise, while the latter was pursuing its prey, and at the instant when by a sudden dash it frightens and drives toward the surface the fry around it, the Tern as suddenly passes over the spot, and picks up a small fish or two.

Nor is the flight of this Tern characterized by the buoyancy and undecidedness, if I may so speak, of the other species mentioned above, it being as firm and steady as that of the Cayenne Tern, excepting during the movements performed in procuring its food. Like some of the smaller gulls, this bird not unfrequently hovers close to the water to pick up floating objects, such as small bits of fat pork and greasy substances thrown overboard purposely for making the experiment. It is not improbable that the habits peculiar to this species, the Noddy, and one or two others, of which I shall have occasion to speak elsewhere, may tend to induce systematic writers to place them in a new "subgenus."

There is a circumstance connected with the habits of the two species of which I now more particularly speak, which, although perhaps somewhat out of place, I can not refrain from introducing here. It is that the Sterna stolida always forms a nest on trees or bushes, on which that bird alights with as much ease as a Crow or Thrush; whereas the Sterna fuliginosa never forms a nest of any sort, but deposits its eggs in a slight cavity which it scoops in the sand under the trees. But, reader, let us return to the Bird Key.

Early the next morning I was put on shore, and remained there until I had completed my observations on the Terns. I pald no attention to their lamentable cries, which were the less piercing that on this occasion I did not molest them in the least. Having seated myself on the shelly sand, which here formed the only soil, I remained almost motionless for several hours, in consequence of which the birds alighted about me, at the distance of only a few yards, so that I could plainly see with what efforts and pains the younger females deposited their eggs. Their bill was open, and their pantings indicated their distress, but after the egg had been expelled, they immediately walked off in an awkward manner, until they reached a place where they could arise 
without striking the branches of the bushes near them, when they flew away. Here and there, in numerous places within twenty yards of me, females, having their complement of eggs, allghted, and quietly commenced the labour of incubation. Now and then a male bird also settled close by, and immediately disgorged a small fish within the reach of the female. After some curious reciprocal nods of their beads, which were doubtless intended as marks of affection, the caterer would fly off. Several indlviduals, which had not commenced laying their eggs; I saw scratch the sand with their feet, in the manner of the common fowl, while searching for food. In the course of this operation, they frequently seated themselves in the shallow basin to try how it fitted their form, or find out what was still wanted to ensure their comfort. Not the least semblance of a quarrel did I observe between any two of these interesting creatures; indeed, they all appeared as if happy members of a single family; and as if to gratify my utmost wishes, a few of them went through the process of courtshlp in my presence. The male birds frequently threw their heads over their back as it were, in the manner of several species of gulls; they also swelled out their throats, walked round the females, and ended by uttering a soft puffing sound as they caressed them. Then the pair for a moment or two walked round each other, and at length rose on wing and soon disappeared. Such is one of the many sights it has been my good fortune to witness, and by each of them have I been deeply impressed with a sense of the pervading power of the Delty.

The Sooty Tern always lays three eggs as its full number, and in no instance, among thousands of the nests which were on the Bird Key, did I find one more when the female was sitting close. I was desirous of ascertaining whether the male and the female Incubate alternately; but this I was unable to do, as the birds frequently left their eggs for half an hour or even three-quarters at a time, bnt rarely longer. This circumstance, together with the very slight difference in size and colour between the sexes, was the cause of my fallure.

It was curious to observe their actions whenever a large party landed on the island. All those not engaged in incubation would immediately rise in the bir and scream aloud; those on the ground would then foin them as quickly as they could, and the whole forming a vast mass, with a broad extended front, would as it were charge us, pass over for fifty yards or so, then suddenly wheel round, and again renew their attack. This they would repeat six or eight times in succession. When the sallors, at our: desire, all shouted as loud as they could, the phalanx would for an instant become perfectly silent, as if to gather our meaning; but the next moment; like a huge wave breaking on the beach, it would rush forward with/deafening noise.

When wounded and seized by the hand, "this bird bites severely, and utters a plaintive ery differing from its usual note, which is loud and shrill, resembling the syllables oo-ee, oo-ee. Their nests are all scooped near the roots or stems of the bushes, and under the shade of their boughs, in many places within a few inches of each other. There is less difference between thelr eggs, than is commonly seen in those of water, birds, both with respect to size and colouring. They generally measure two inches aud one-ighth, by one and a half, have a smooth shell, with the ground of a pale cream colour, sparingly marked with various tinges of lightish umber, and still lighter marks of purple, which appear as if within the shell. The Lieutenant, $\mathbf{N}$. Lacoste, Lsq., informed me that shortly after the young are batched, they ramble pell-mell over the island, to meet their parents, and be fed by them; that these birds have been known to collect there for the purpose of breeding, since the oldest wreckers on that coast can recollect; and that they usually arrive in May, and remain until the beginning of August, when they retire southward to spend the winter months. 
I could not however obtain a sufficiently accurate description of the different states of plumage which they go through, so as to enable me to describe them in the manner I should wish to do. All that I can say is, that before they take their departure, the young are grayish-brown above, dull white beneath, and have the tail very short.

At Bird Key we found a party of Spanish Eggers from Havannah. They had already laid in a cargo of about eight tons of the eggs of this Tern and the Noddy. On asking them how many they supposed they had, they answered that they never counted them, eren while selling them, but disposed of them at seventy-five cents per gallon; and that one turn to market sometimes produced upwards of two hundred dollars, while it took only a week to sail backwards and forwards and collect their cargo. Some eggers; who now and then come from Key West, sell their eggs at twelve and a half cents the dozen; but whereever these eggs are carried, they must soon be disposed of and eaten, for they become putrid in a few weeks.

On referring to my journal once more, I find the following remarks with reference to the Sooty Tern. It would appear that at some period not very remote, the Noddy, Sterna stolida, must have had it in contemplation to appropriate to itself its neighbour's domains; as on examination of this island, several thousand nests of that bird were found built on the tops of the bushes, although no birds of the species were about them. It is therefore probable that if such an attempt was made by them, they were defeated and forced to confine themselves to the neighbouring island, where they breed by themselves, although it is only a few miles distant. That such interferences and conflicts now and then occur among different species of birds, has often been observed by other persons, and in several instances by myself, particularly among Herons. In these cases, right or wrong, the stronger party never fails to dislodge the weaker, and keep possession of the disputed ground.

Soon after the birds arrive on the island a nesting site is sought, Dr. Watson gives a most graphic account of this. I shall therefore let him speak.

git My observations began late one afternoon, before any eggs had been laid. Hundreds of the birds were grouped together, incessantly fighting and screariing. It quickly became apparent that most of them had chosen a nest site and were defending it against all late comers. Both male and female were present. Each pair in this particular locality defended a circular territory, roughly 14 Inches to 2 feet in diameter. Other birds in wandering around would stumble into this sacred territory and a fight would ensue. The fights would often lead to encroachments upon the territory of still other birds. The number of those fighting would thus be constantly. increased. I have seen as many as 14 sooties thus engaging in a fight. Birds 10 and 15 feet away would rush into the fight and the noise and confusion beggared description. Sometimes as many as 10 or 15 such fighting groups could be observed in the area of 1,000 square feet. Quiet would momentarily ensue and then be broken by another series of fights. During the cholce of the nesting site the fights continue day and night, with only Intermittent periods of quiet.

Of the actual nest construction he tells the following:

The actual construction of the nest, when a nest structure is formed, begins after an undefended area has been found. The process of nest building is somewhat as follows: The bird puts the breast to the ground, thereby supporting the body and leaving the legs comparatively free. The feet are used as a com- 
bined scraper and shovel. A few backward strokes of the feet are made, which serve both to loosen the sand and to remove it from beneath the body. The bird then turns slightly and repeats the process. When it has turned $360^{\circ}$ (or less) it begins to use the breast as a shaper. By continuing this process, the depression is soon made to assume the required diameter and depth. My notes show that the bay cedar leaves are often gathered up and placed around the rim of the nest as the hole is being dug. I can not say which sex does the work, but $I$ believe that both male and female engage in it. As soon as the depression is made, both birds begin to defend it. Naturally, where no nest is made, the nest site alone is chosen and defended as described above.

An approximate count of the total number of the sooty nests was made in 1908 in the following way: Those parts of the surface of the island containing nests were subdivided into 10 separate areas. The number of square feet in each area was next determined. The average number of nests (spots where eggs were deposited) per square foot was then determined separately for each area. By means of these data, the total (approximate) number of nests on the island was found to be 9,429. Multiplying by two, as in the previous case, we have 18,858 as the total number of aduit sooties. It may be said that the above determination was made late in the brooding season, after all the eggs had been laid. It may also be of interest to note that in localities where the nests are very numerous they often are not more than 10 to 12 inches apart.

Plates 5, 6, 8 show the disposition of the nests, for each bird in the picture is occupying his home.

The sooty usually lays but one egg, though occasionally two are deposited. Watson found only 25 nests containing more than one egg in all the thousands examined and but a single one in which two birds were actually hatched and reared. On plate 8 are figured five eggs selected to show the greatest range of color variation observed, for although the general type of coloration is very similar, a considerable diversity is found to be present when one actually searches for variations from the typical form which is represented by the figure.

Watson gives us an intimate picture of the changes that take place in the habits of the adult bird during the various stages of the cycle that begins with nest building and probably ends with the birds leaving the island. He has with infinite patience worked out the daily life routine, with all of its vicissitudes, of the young bird from the time it breaks from the shell until it finds its wings. I shall therefore let him speak.

The general disposition of the sooty, like that of the noddy, changes after the egg is lald and in the same way. Some of them become far bolder than the noddies in a corresponding situation. It was possible for me to lle down within a few inches of a brooding sooty and have it remain on the nest indefinitely. If the hand is extended toward the sooty it wlll attack vigorously, but I have never had a group of flying sooties attack me as I approached the ricinity of their nests, as was sometimes the case when $I$ ventured too near the nests of the noddies. The birds are very variable in this respect. When one approaches a neighborhood containing many nests, the majority of the birds will fly up into the air, circling round and round, screaming all the while. If one remains quiet, the birds will gradually return and cover the eggs. Gradually 
the nests nearest one's position will be cautiously approached and then occupied. A certain smarr percentage of the birds will remain on the nest, no matter how violent the disturbance.

It appears *** that the shift at the nest is roughly a diurnal one, but that at times it may not occur except once in 48 hours. * * * Apparently most of the shifts are made at night. I attempted on many occasions to determine the hour of shifting by leaving a lantern near the nest and making observations during the night, but the light could not be arranged so as not to frighten the birds, and their reactions consequently were not natural. The birds would refuse to cover their eggs if the light were made intense enough to be of value to me.

Watson tells us that observation on 16 marked nests proved that the period of incubation for the sooty is 26 days. We continue to quote from him:

During the first three days after the appearance of the young, the sooty is reluctant to leave the youug and nest on disturbance. Later the rdults fiy away at the slightest disturbance, much as they do during the "laying" season. It is interesting to observe at every disturbance of a nesting place how quickly the ground will be deserted by both young and old, after the young have reached the age of 3 days. As they leave, the alarm cry is sounded and. the commotion spreads to all the near-by nests. When quiet is restored the birds again alight near the nest and gradually approach it. The young birds meantime have run to the bushes, where they remain motionless after sticking their heads into the crotch of some bush or depressing the body against any convenient solid object. The protective coloring of the young sooties is marked. When motionless, as above suggested, they are difficult to find. When the adult returns to the nest, the young birds gradually come from their hiding places at the peculiar clucking call of the parent. The parents (after the first ferw days) recognize their own offspring with ease and accuracy, often going to meet them as they emerge from the bushes.

The adult would circle over the area and give a call; it would be answered and random movements would give place to direct. The bird would steer immediately for the source of the call. By peculiar chuckling sounds, which are emitted at this period when mates return, one can be sure that the proper nest has been located. I observed this many times during one evening. After the young were 20 to 30 days old $I$ have heard the young birds answer the call of the parent back and forth a dozen times before the latter actually allghted.

Neither young nor old is quiet during this period of the nesting season. On the contrary, the noise is practically doubled. In addition to the ordinary sounds made by the adults and the new eries which are added at this time, there is present the high-pitched, insistent "peep-peep" of the young terns. Momentarily the sounds of the adults will cease and the cries of the little ones remind one very strongly of a poultry yard on a tremendous scale.

Though the parents feed the young at any hour of the day, feeding can bemost easily observed at dusk. It has already been mentioned that the sooties hurry home at nightfall in great numbers. From 4 until $8 \mathrm{p}$. $\mathrm{m}$. this feeding process keeps the island in commotion. The feeding of the young birds has: many interested spectators. While I have never seen the terns from the neighboring nests, which may be observing the process, attempt to rob the young bird, I judge from the actions of the feeding parent that such is occasionally the case. If the parent happens to disgorge more than the young tern can take Into its 
beak and the food is allowed to fall to the ground, it is ludicrous to watch the rapidity with which the parent picks up the food and reswallows it. Oftentimes the mate of the feeding parent is near; its rôle is a purely passive one except when the "spectators" attempt to approach too near. Its part is then to assist in warding them off ****

The parents alternately feed the young, but instead of a diurnal period of feeding, such as the parents have before the appearance of the young, the intervals vary anywhere from four to seven hours.

The care of the young, especially from 20 days on, must be an exhausting frocess for the parents. They become emaciated and somewhat bedraggled in appearance. This is not to be wondered at when we consider that a healthy young sooty can eat anywhere from 20 to 40 minnows of no insignificant size in a day. It may be of general interest to note that after the first few days the parent always recognizes and feeds its own young and no others, and furthermore, the young tern recognizes its own parents and attempts to feed only from them. Never but once out of many thousands of observations did I see a young tern begging food from a stranger.

Watson and Lashley have shown conclusively by a large series of experiments that the sooty tern seems to entertain man's legal aspect of property rights.

Many attempts were made to shift nests to the edge of the beach with the purpose of transferring them to rafts in the hope of ultimately transplanting a part of the colony to other keys, but however slowly such shifts were made ( 6 inches or so per day) the nests were either abandoned when moved 4 feet or less from their original position, or the eggs were rolled back as fast as they could be moved forward.

On the other hand, a vertical elevation of the nest to a considerable height did not cause its abandonment, as shown by the following experiment made by Watson:

A nest was chosen in an open space, but very close to some bushes. I obliterated the nest as the bird had constructed it, inserted a black pan, filled this with sand, and constructed a nest inside of it. This gave me an opportunity to move the nest upuard as well as laterally. On returning, the bird alighted on the nest without showing any signs of disturbance. An hour later I came back and pulled the pan out of the sand and put a few stleks under it. The bird returned, but was not disturbed by this slight change. I then drove in four stakes 10 centimeters high and mounted the pan thereon. This served to raise the nest upward without disturbing the other relations of the nest. The bird on returning alighted immediately on nest. The other birds gathered around. craning their necks and peering upward. The bird then stood up and came to the edge of the pan and peered down. This seemed to disturb it and it flew to the ground, but hopped up again immediately, covered the egg and sat there in comfort the rest of the day. Raising the nest 10 centimeters in the air requires almost no adjustment on the part of the bird. On account of a storm on the island, which lasted for two days, no further experiments were made at this time on this nest. I next raised this nest 100 centimeters; bird alighted immediately squarely on the top of the nest; did not make a false movement. On eraning neck over the edge of the pan a little later, however, became disturbed and alighted on the ground, and remained there for 45 minutes without attempting again to get on nest. I forced the bird to fly up. Agaln 
alighted on the nest and began to brood the egg in comfort. On my return several hours later it was still sitting quietly on nest.

On the second day after this (when this same bird was at the nest again) I lowered the nest back to 10 centimeters, its first vertical position. On returning the bird alighted squarely on the nest, making perfect adjustment. I scared the bird away. On its return the bird again adjusted accurately. I next mored the nest back to the height of 100 centimeters. Bird returned and alighted on egg and adjusted to it before I could get back to my position in the bushes. Adjustment in the rertical plane is made with exceeding rapidity and ease.

$I$ then moved the nest 100 centimeters to the east, leaving it 100 centimeters above the ground. Behavior of bird very interesting. Would not alight on nest. Alighted at the former ground position. After a long time flew from the old position and up to new position of nest. Immediately hopped down and began a most peculiar performance. Bird vould hover in space, attempting to adjust to the nest in the air at its former position and height. It would then fly away again and come back to the old position and try to alight in space. This was done 20 times. At the end of 20 minutes the bird alighted upon the pan in its new position and sat down on egg. I then scared the bird away 5 successire times, to see if it would alight immediately upon the pan. Each time on returning the bird alighted at the old ground position and proceeded from this point to the new position of the nest.

I then put the pan back in its old position. Bird returned and alighted on pan immediately. In this position $I$ then raised the pan to a height of 200 centimeters. This raised the nest well up above any of the surrounding bushes. This did not cause the bird the slightest disturbance. I forced it to make three or four adjustments to the nest in immediate succession. It made them all with equal precision.

Watson tells us that the habit which he has called the sunning reaction in the noddies, while present to some extent before the appearance of the young, shows itself in completed form as the development of the young progresses. He also states that he has never seen sooties roosting upon stakes and buoys, etc., but that "the sooty always leaves the island and returns to it without at any time having ceased its flight. This seems rather remarkable when we take into account the fact that the sooty leaves the island in the early morning and oftentimes does not return until toward nightfall."

At times, however, they do rest in elevated positions, as shown in plate 4 , in which a group of sooties is occupying the tops of a bunch of bay cedars.

When flying low over the water to the fishing ground the sooty resembles the black skimmer in its flight to such a remarkable degree that I have very often been forced to pick up my glass in the hope of listing this bird for the Tortugas region. The fishing is done by quickly picking up such small fry as may be forced to jump abore the surface by pursuing larger fish. The birds may be seen fishing singly or sometimes a hundred or more of both noddies and sooties 
may be present. The number usually depends upon the size of the harassed school of fish.

\section{As to the nocturnal activities of the birds, Watson states:}

From other observations, too numerous to mention separately, I conclude that all birds return to the island at night. Many times just at sundown I have come from Loggerhead Key to Bird Key. The terns are coming in by hundreds and thousands, flying low over the water. By the time twilight has faded the water is entirely deserted. Several trips made to Fort Jefferson late at night showed that these birds do not leave the island at night. The moment the island is reached, however, no matter at what hour of the night, cne finds the sooties busily flying from one place to another on it.

An interesting pastime of the sooties is described by Watson.

The sooties often soar round and round, getting higher and higher until lost to sight. They usually join the frigate birds in this reaction. I am inclined to think that the sooty when sufficiently fed spends a large part of its time in such maneuvers.

It will circle in the air again and again, giving out the shrill nasal alarm cry of eäh, éäh, eäh. It is the most restless and noisy bird I know, and almost as much so at night as during the day. Sleep apparently is taken during both day and night by dozing momentarily at intervals. How the bird maintains its vigor with no more continuous rest than it takes is a mystery. This peculiarity of the sooty has led to the popular nickname of "wide-awake tern."

\section{THE NODDY TERN (Anoüs stolidus).}

Here, as in the case of the sooty tern, we are indebted to Audubon Ior the first account of this colony. I shall quote what he has to tell us of his experience with these birds on the Tortugas in 1832. This sketch is the more interesting on account of the fact that the birds no longer breed upon the key (Bush Key) on which he found them nesting, as all the vegetation, in fact, most everything shiftable above the sea, has long since been swept away by the waves. His reference to noddy nests on Bird Key mentioned in his sooty tern biography shows that noddies had built nests in the bay cedars of that key, although he states that they were not occupied at the time of his visit. Since then the colony has been forced to make a complete shift and the choice between Bird and Loggerhead Key has fallen to the former, where Watson estimated the presence of 1,400 adult birds in 1908. We shall now quote from Audubon.

About the beginning of May, the Noddies collect from all parts of the Gulf of Mexico, and the coasts of Florida, for the purpose of returning to their breeding places, on one of the Tortugas called Noddy Key. They nearly equal in number the Sooty Terns, which also breed on an island a few miles distant. The Noddies form regular nests of twigs and dry grass, which they place on the bushes or low trees, but never on the ground. On visiting their island on the 11th of May, 1832, I was surprised to see that many of them were repairing and augmenting nests that had remained through the winter, while others were employed in constructing new ones, and some were already sitting on their 
eggs. In a great many instances, the repaired nests formed masses nearly two feet in height, and yet all of them had only a slight hollow for the eggs, broken shells of which were found among the entire ones, as if they had been purposely placed there. The birds did not discontinue their labours, although there were nine or ten of us walking among the bushes, and when we had gone a few rards into the thicket, thousands of them flew quite low over us, some at times coming so close as to enable us to catch a few of them with the hand. On one side might be seen a Noddy carrying a stick in its bill, or a bird picking up something from the ground to add to its nest; on the other several were seen sitting on their eggs unconscious of danger, while their mates brought them food. The greater part rose on wing as we advanced, but re-alighted as soon as we had passed. The bushes were rarely taller than ourselves, so that we could easily see the eggs in the nests. This was quite a new sight to me, and not less pleasing than unexpected.

The Noddy, like most other species of Terns, lays three eggs, which average two inches in length, by an inch and three-eighths in breadth, and are of a reddish-yellow colour, spotted and patched with dull red and faint purple. They afford excellent eating, and our sailors seldom failed to collect bucketfuls of them daily during our stay at the Tortugas. The wreckers assured me that the young birds remain along with the old through the winter, in which respect the Noddy, if this account be correct, differs from other species, the young of which keep by themselves until spring.

At the approach of a boat, the Noddies never flew off their island, in the manner of the Sooty Terns. They appeared to go farther out to sea than those birds, in search of their food, which consists of fishes mostly caught amid the floating sea-weeds, these Terns seizing them, not by plunging perpendlcularly downwards, as other species do, but by skimming close over the surface in the manner of Gulls, and also by alighting and swimming around the edges of the weeds. This I had abundant opportunities of seeing while on the Gulf of Mexico.

The flight of this bird greatly resembles that of the Night Hawk when passing over meadows or rivers. When about to alight on the water the Noddy keeps its wings extended upwards, and touches it first with its feet. It swims with considerable buoyancy and grace, and at times immerses its head to seize $u$ fish. It does not see well by night, and it is perhaps for this reason that it frequently alights on the spars of vessels, where it sleeps so sound that the seamen often catch them. When seized in the hand, it utters a rough сry, not unlike that of a young American Crow taken from the nest. On such occasions, it does not disgorge its food, like the Cayenne Tern and other species although it bites severely with quickly repeated movements of the bill, which, on missing the object aimed at, snaps like that of our larger Fly-catchers. Some which I kept several days refused all kinds of food, became dull and languid, and at length died.

While hovering over us near their nests, these birds emitted a low querulous murmur, and, if unmolested, would attempt to alight on our heads. After a few visits, however, they became rather more careful of themselves, although the sitting birds often suffered us to put a hat over them. Like the Sooty Tern, this species incubates both day and night. The differences exhibited by Terns with respect to their mode of nestling and incubation, are great, even in the same neighbourhood, and under the same degree of atmospheric temperature. This species breeds on bushes or low trees, placing several nests on the same bush, or in fact as many as it will hold. The Sterna fuliginosa scoops out a slight hollow in the sana, under the bushes, without forming any nest, and in- 
cubates closely like the former. The Sandwich, the Cayenne, and the Roseate Terns, drop their eggs on the sand or the bare rock, and seldom sit upon them until evening, or during cloudy or rainy weather. The Cayenne, Sooty and Noddy Terns differ greatly in their flight, their manner of feeding, and the extent of their migrations. The tail of the Noddy is cuneate, instead of being forked, in which respect it differs essentially from that of the other species. Perhaps the naturalists who placed it in the same genus with the Roseate Tern may have been nodding over their books.

The several years of study by Watson and Lashley have added much to our knowledge of this species, and I shall take the liberty to quote from them extensively in order to render the picture as complete as possible.

\section{Of the mating, Watson states:}

My notes contain a rather full account of a striking series of reactions between two noddies which I took to be a case of mating and choice of nest site, but since it occurred late in the season and did not lead to a completed nest, $I$ advance it tentatively.

One day I observed several noddies "sunning" upon the wire corering of one of my large experimental cages. Suddenly, one of the birds (male) began nodding and bowing to a bird standing near (female). This nodding reaction is one of the most interesting and ludicrous acts of the Noddy Tern. It is quite elaborate. Two birds will face each other, one will then bow the head alnost to the ground, raise it quickly almost to a vertical position, and then quickly lower it. He will repeat this over and over again with great rapidity. The other bird goes through a similar pantomime. If a stranger bird alights near the group, he salutes those nearest, and is in turn saluted by them. During the pantomime a sound is rarely made. The female gave immediate attention and began efforts to extract fish from the throat of the male. The male would first make efforts to disgorge, then put the tip of the beak almost to the ground and incline it to the angle most suitable to admit her beak. She would then thrust her beak into his (the ordinary feeding reaction). The feeding reaction was alternated with the nodding. After this series of acts had been repeated 20 times, the male flew off and brought a stick. He deposited this near the female and then again offered to feed her. She again tried to feed, then the male attempted sexual relations. She immediately flew away, but almost immediately returned and alighted at a slightly different place. The male again brought the stick and again bowed and offered to feed her. She accepted the food, but again flew away when the male attempted to mount her. At this juncture the island was disturbed and my observations could not continue.

The noddy constructs its nest from (1) loose dead branches of the bay cedar bushes; (2) of seaweed; (3) of a combination of these ; (4) of a combination of either or both of these with various kinds of sea shelis and coral. When the shells and coral are employed, they are often placed as an inner lining to the nest and the egg is deposited directly upon them. The nest itself is a quite variable structure, and usually loosely put together. It is very shallow, and this is rather singular, since the wind often blows the egg or the young to the ground.

The nests remaining from year to year are utilized by the birds at successive nesting periods; whether or not by the same pair can not with certainty be answered at present. On account of this utilization of the old nest from 
year to year, some of the oldest nests have grown to enormous size, due to the addition of new materials at each successlve season.

Both birds work, bringing sticks, seaweed, shells, and coral. Both birds shape the nest clumsily by pecking and pulling at the sticks. They never weave the sticks so as to form a compact and durable nest. The stick is dropped on the rim, then drawn into position. Frequently, first one bird, then the other, sits in the nest and shapes it. In order to do this the bird rises on its feet and depresses its breast and turns round and round. The material is obtained both far and near. Floating sticks and seaweed are gathered from the water. They frequently alight under the nests of other birds and gather up the fallen branches. They even take the material from other nests which are left momentarily unguarded. Frequently fights ensue. The birds work neither steadily nor rapidly; 10, 15, 20 minutes elapse before either makes a trip.

Very often the nest has the appearance of being constructed directly upon the ground, but a closer examination usually shows that it has been built upon a tuft of grass or upon the stem of a bush, the branches of which have been broken off close to the ground. The nearest approach I found to the laying of the egg upon the bare ground was in the case of two nests built on a bare horizontal board lying among the cactus growth. In each of these cases the egg was laid directly upon the board, but some dozen or two small sticks re tained the egg in position.

While observing the noddies at work upon the nest, it soon became apparent that the daily routine of the female was different from that of the male. From many hundreds of observations it was also evident that the male feeds the female at more or less regular intervals. * * *

The male returns with a full-laden crop. He alights directly upon the nest or near the female. The female at once shows signs of life, and as they approach each other they begin nodding. Then the male invites the female to feed by putting his beak down in a position convenient to her. She gets the food by taking it directly from the mouth of the male, the male disgorging it by successive muscular contractions of the throat and abdomen. The impression one gets from this ludicrous performence is that the bird is choking to death. During the whole of the process of feeding a soft, nasal, rattling purr is emitted, presumably by the female. This purring sound is an invariable indication that feeding is taking place. It is to be heard on no other occasion.

After the egg is laid a marked change appears in the behavior of both the male and the female. The birds will attack even a human intruder, and their defense of the nest against their own kind becomes even more strict than before. Oftentimes the birds will sit on the egg and allow themselves to be caught, striking viciously all the while with their long, keen, pointed beaks. Individuals vary greatly in this respect. On my daily rounds, as I approached the vicinity of a group of nests, several noddies would usually advance to meet me, striking viciously at my head. Their attacks would continue until I withdrew. Many times I have had my hat knocked off and the blood brought from my scalp by their vicious attacks.

Still another marked change occurs in the habits of the birds: The male no longer feeds the female. Each bird takes equal turns at brooding the egg. My attention was first called to this whlle I was watching the habits of the birds before the egg was laid. Several nests in the vicinity of the place of observation already contained eggs. At these nests I was never able to observe the feeding of the female by the male. At this period the two birds become practically automata. Their life is taken up in alternately brooding the egg

$65133^{\circ}-\mathrm{SM} 1917-32$ 
and in feeding. The blrds spend little or no time together except at night. The one comes to the nest, the other flies away to feed.

The period of incubation varies for the noddy from 32 to 35 days. This fact was determined on the basis of 16 observations. The young began to appear on the island about May 9 (1917).

The young are cared for in the nest until they become strong enough to leave it and live upon the ground. The young birds born in low nests, even at a very early age (20 days and even earlier), clamber from them with alacrity and hide in near-by bushes when danger is imminent. In many cases these young birds can not get back to the nest. Under these circumstances they remain near the nest locality, and the parents on returning first alight on or near the nest and later hop to the ground and feed the young bird. ***

As the young advance in age (20 days and at all later ages) the parent will readily leave the nest when disturbed. The tendency in this respect is to revert to the behavior exhibited during the egg-laying season.

Examination of the stomach contents of both young noddies and sooties showed the presence of representatives of the two families of fish, Carangidae and Clupeidae. * * *

The birds fish by following schools of minnows which are being attacked by larger fish. The minnow, in its efforts to escape, jumps out of the water and skims the surface for a short distance. The terns pick off these minnows as they hop up above and over the surface of the water. ****

The birds feed singly or in groups, usually in groups. The group may be composed of both noddies and sootles and may contain sometimes as many as 50 to 100 individuals. All during the day groups of noodies and sooties may be seen at work. As the minnows cease to jump above the surface of the water, the group disbands and scatters in every direction. An instant later, as an attack is made upon the minnows in some other locality, the birds immediately rush there and renew their feeding. (See plate 21.)

In this connection I would add that $I$ hare at such times seen noddies dive for their prey with almost the same vigor that the common and least terns engage in their pursuit.

\section{I will let Watson continue.}

Apparently, at the end of two hours the noddy has supplied its needs, for at this time it returns to the island and relieves its mate at the nest. The latter then comes out upon the water and takes, roughly, a two-hour turn at fishing, then likewise returns to the nest. This routine of spending two hours at the nest and two hours on the water is engaged in by all of the noddies during the seasons of brooding and of rearing the young.

\section{Watson and Lashley also record an interesting and rather rare habit.}

In 1910 we saw one noddy fly into the water, fold its wings, and begin swimming like a duck. About 10 other noddies joined this one. This is the only occasion upon which we have ever witnessed swimming movements. We have never seen the sooty in the water, except when accident has overtaken it.

There is one rather interesting difference between the habits of the noddy and those of the sooty which may be mentioned here: Every stake, buoy, or possible resting place upon the water is utilized by the noddy. It will sit almost motionless upon any object projecting from the water for long periods of time. This habit of theirs is like that found in the cormorants, boobies, and pelicans which are present in the neighborhood. 
Speaking of the sunning habits of the noddy, Watson states:

Although the reaction is at bottom gregarious * * * the birds are stolidly indifferent to one another's presence. They sit silent, head to the wind, elaborately preening their feathers, pecking first at one toe, then at another. Occasionally when another noddy joins the group a mutual nodding is engaged in which at times for no observable reason ends in a fight. The birds here as elsewhere are silent. It is interesting to note that a definite distance is maintained between birds engaged in this activity. The distance is determined, I believe, by the long diameter of the body of the bird-they must have a free space in which to turn. I have seen 10 to 12 birds upon the comb of the roof of the house separated from one another by distances so regular that the unaided eye can with difficulty distinguish inequalities in the spacing.

At night the two birds usually remain in branches near the nest, but if disturbed, both fly away for a short distance and circle back almost immediately to the nest. In flying at night both the noddy and the sooty break their graceful flight into short, ungraceful, and ill-directed choppy swoops, very similar to the way the nighthawk breaks its flight when flying after dusk.

THE LEAST TERN (Sternula antillarum antillarum).

The call for bird plumage with which to decorate feminine hats: bade well to exterminate this most diminutive of our terns. Thanks to the good work of the Audubon Society, enough were saved to. leave a remnant for restocking. A small colony formerly bred on the southern end of Loggerhead Key, but the persistent efforts of eggers have banished the species from that island. Last year (1916), however, a single pair reestablished itself here and our plate 22 represents these individuals.

The southern sandy end of Long Key boasts of a colony of about. 200 pairs.

The nest of the least tern is a mere hollow scraped in the sand in which the two, sometimes three, or very rarely four eggs are placed. Not a bit of lining is used, nor is there a rim of shells or shell fragments placed about the edge of the nest, as is done by some of the other terns. The nests are always scattered, never crowded. The eggs harmonize extremely well with the coloration of the sand and are very difficult to see, even at a distance of 6 feet. It is their shadow that usually relieves them from the sand, and aids in revealing their presence if you walk on the shady side. The young. birds are equally well protected by their mottled coloration, and the tiny chaps seem well aware of this, for they will press themselves. flatly against the gravel or shelly beach and remain perfectly motionless as long as danger threatens. At such times they are extremely difficult to see, and it is usually the dark eye, though partly closed, that offers the greatest contrast and gives the clue to the whereabouts. of the little fellows. It is remarkable how this harmonious coloration effectively appears to eliminate an entire colony from the scene, save the flying, piping, and screeching parents. One may, for example, 
pass over the sand flat of Long Key after the young have slipped from their shell, and not see a dozen young birds, but set up your tent on the breeding grounds, and take a station within it, and you will soon see the parents arrive and their call will cause the little fellows to appear on all sides and run up to the parents to accept the dangling minnow from their bill. They seem to be springing from the very ground, for places which you may have carefully scrutinized only a few moments before and passed as sand only, now yield these tiny, animated fluffs of down. A little later the young birds follow the shore line of the beaches, where they indulge in the never-ending occupation of preening the growing feathers, wading, bathing, and occasionally taking a swim. If you surprise them at such a time they will boldly strike out from shore to rapidly place as much distance between you as possible; after a wide detour to the beach, they will make a rapid rush for the cover of the rougher ground or vegetation. Our figures show birds in various stages of development, usually in the hiding place.

The adult least tern, so far as I know, has no enemies while on the breeding ground. The eggs, however, and probably the young are destroyed by the ghost crab (Ocypode albicans Bosc.) (pl. 26). I have seen large members of this species sidle up to the resting terns and in spite of the rigorous wing beating to which they were subjected, force the bird from the place which it was occupying, This persistent annoyance on the part of the crab appears to permit of but one interpretation; that is, that they are after eggs or young fledglings. I have twice found young birds that had escaped with a partially clipped off wing. One of these, almost fledged (pl. 25), had the primary portion of its wing clipped off very recently, for the wing was still bleeding when the bird was found. The young least terns may also fall the prey of the few laughing gulls that frequent the breeding ground during the season, and it is equally possible that the man-o'-war birds occasionally stoop for these tiny. morsels.

The fishing of these little terns is a marvelous thing. They are by far the most active and quickest members of the entire group, a bundle of nervous energy. They speed over the shallow lagoon until a place is found where, at this season, small fish fry congregate in countless numbers, then a momentary halt, a headlong plunge, a dive with sufficient force to make you fear for the safety of the bird as he strikes the water, but it is only a moment, and he is back in the air, shivers the water from his feathery dress, talking, meanwhile, in his ever-pleasant chatty way as he heads for his family with his slender shining prey.

I wish that you might spend a couple of hours within my tent on the breeding grounds of these beautiful creatures and watch their 
home life; see the pride with which the male comes: with the food for his mate, for he provides for her during the incubation period, and note how coyly she accepts it, and listen to the music of their conversation, for the male apparently begins to tell about how he caught it the moment he heads for shore. At times you would be greatly amused to see how he teasingly refuses to relinquish a choice shiner, turning it before her, now on this side, then on the other, ever deftly squirming to keep it from her; such, and many other little tendernesses occasionally observed in creatures of a higher order, are the order of the day. An hour of watching these swallows of the sea gives one a feeling of kinship and materially expands one's sympathies for the larger universe.

THE ROSEATE TERN (Sterna dougalli).

Last year (1917) a colony of about 100 pairs of the roseate tern established itself on the rough coral and shell-strewn northeastern end of Long Key. During the time of my visit, the last 12 days of July, no eggs were found, but young in various stages of development from a few days old to individuals just finding their wings. It was interesting to quietly drift up the shallow bay inclosed in the curve of Long and Bush Key and on landing at the northern end, make a rush across the narrow hurricane rampart that connects Long with Bush Key. The outer shoal of this rough portion of the key formed the habitat frequented by the young birds.

The result of such a sudden visit would be to put all of the adult birds in the air screaming a concerted protest to the intruder (pl. 27), while the young birds would execute a quick scramble for shelter or the water. In a few minutes a raft of small birds would be swimming in a compact body at some distance offshore (pl. 32), and of those remaining on land not one would be in sight. A careful hunt; however, would soon reveal them tucked away in the crevices between the coral boulders, sometimes several young birds under a single coral head. When possible they will crawl completely from sight, but if no cover is present, they will content themselves by merely hiding their heads, as shown by our pictures (pl. 29). At times, too, they merely flatten themselres against the rough ground (pl. 30 , fig. A). No matter what their position may be, the young birds are always completely in harmony with their surroundings; the colora. tion of the young birds is in perfect accord with the general color scheme. We have given a number of plates showing the different developmental stages of the bird and its plumage.

THE BLACK TERN (Chlidonias nigra surinamensis).

During last summer's visit we found this aberrantly colored member of the sea swallows present on Long Key during my entire stay at 
the Tortugas; that is, from July 19 until the end of the month. There were at least two dozen birds varying in plumage from the adult blacks through the checkered of the adolescent to the immature of the year. Their occurrence at this time seems to almost indicate that they might have bred here, but I greatly doubt that this could have been the case, for we have no record of black terns breeding anywhere nearly as far south as this. I also failed to find any signs of nests, which I am sure I should have been able to locate had they been present, for I am thoroughly familiar with their nesting habits in the North.

\section{THE ROYAL TERN (Thalasseus maximus).}

A few royal terns are always to be found about the Tortugas during the spring and summer months, but we have no record of their breeding here. A bunch of 14 frequented the northern hook of Loggerhead Key on fair days where they would preen and doze for hours at a time, usually during the warmer parts of the day, in which occupation they were frequently joined by an even larger number of least terns. Plate 37 , figure B, shows the birds in this place in characteristic poses.

\section{THE MAN-O'-WAR BIRD (Fregata magnificens rothschildi).}

Until the young noddy and sooty have slipped from their shell, man-o'-war birds are not especially abundant about the Tortugas. It is true, Fort Jefferson, some old stakes and pieces of wreckage on Bird Key, and on the outer reef, furnish desirable resting places for them, and the abundance of fish likewise an adequate food supply, so that there may be a few more birds here at all times than one would see along the rest of the keys, excepting, of course, their roosting place, the little island near New Found Harbor Key and Key West, whose refuse furnishes a never failing food supply.

However, when the young terns begin to appear on the ground, the man-o'-war birds increase in numbers until four to five hundred will be found crowding all the available wreckage on Bird Key (pl. 36), where they augment their finny diet by occasionally swallowing a young tern. I have seen them pick up and fly away with an almost. fledged bird. We will, therefore, have to consider the man-o-'war bird an enemy of the tern.

If you come to dislike the man-o'-war bird for his pilfering on the tern rookeries, you soon lose your dislike when you see him on wing, for there is no bird in existence that equals him when it comes to soaring, a feat for which every airman who sees him envies him.

Fort Jefferson, on Garden Key, is an ideal place from which to study his powers of wing. The high wall that circles the structure catches the slightest breeze that may ripple the sea and causes the 
air to be upthrust on the windward side, and upon this column of air the man-o'-war birds will poise themselves with such perfect balance that they seem fixed to a certain spot in the sky. A hundred or more birds at a time may be seen thus hanging motionless suspended over the northeast portion of the fort, low down when the wind is slight, and high up when strong, always in the place which suits their powers of adjustment best.

Their power of vision is likewise marvelous. I recall being at work in a shallow stretch of water when a fish broke above the surface, evidently pursued by a larger member of the finny tribe. A brown pelican at once gave chase and almost reached him, as the fish leaped from the water the third time in short intervals, but a man-o'war bird that had been suspended way up in the air so high as to appear a mere speck, came down with a rush and snatched it almost from the very beak of the pelican. I have many times since enjoyed casting fish out into the water of Key West Harbor to watch the speed with which man-o'-war birds, soaring high up in the air, will notice them and stoop to pick them up without touching a feather or missing a strike. Our plates 33,34 , and 35 show a series of pictures giving different poses, responses to such baiting in Key West Harbor, while plate 36 shows the man-o'-war birds on Bird Key.

At times a superior-winged man-o'-war bird will give chase to a less endowed individual that has captured a fish and worry him until he disgorges it. The pursuing bird will quickly follow the falling fish and snatch it before it reaches the water. The gulls and boobies are similarly parasitized by the man-o'-war.

Dr. Charles H. Townsend, the director of the New York Aquarium, gives an interesting brief account on the homing of the man-o'-war bird, from which the following quotation is taken:

In the course of a winter's voyage on the U. S. S. Albatross in the South Seas, the writer found among the natives of the Low Archipelago many tame frigate birds. The latter were observed on horizontal perches near the houses, and were supposed to be merely the pets of the children who fed them.

They were entirely tame, having been reared in captivity from the nest. As our acquaintance with the people developed, we discovered that the birds were used by them after the manner of homing "pigeons" to carry messages among the islands.

The numerous islands of the Low Archipelago extend for more than a thousand miles in a northwest and southeast direction, and it appears that the birds return promptly when liberated from quite distant islands. They are distributed by being put aboard small vessels trading among the islands. The birds are liberated whenever there is news to be carried, returning to their perches sometimes in an hour or less from islands just below the horizon and out of sight of the home base. Generally they are in no great hurry. As the food of the frigate bird may be picked up almost anywhere at sea, there is no means of ascertaining how much time the bird loses in feeding or trying to feed en route. It may also linger to enjoy its liberty with other frigate birds. 
I did not observe tame frigate birds elsewhere in Polynesia, but Mr. Louis Becke, who is familiar with most of the South Sea Islands, says they were used as letter carriers on the Samoan Islands when he was there in 1882, carrying messages between islands 60 to 80 miles apart. When he lived on Nanomaga, one of these islands, he exchanged two tame frigate-birds with a trader living on Nuitao, 60 miles distant, for a tame pair reared on that island.

The four birds at liberty frequently passed from one island to the other on their own account, all going together on visits to each other's homes, where they were fed by the natives on their old perches. Mr. Becke's pair usually returned to him within 24 to 36 hours. He tested the speed of the frigate by sending one of his birds by ressel to Nuitao where it was liberated with a message at half past 4 in the afternoon. Before 6 o'clock of the same day the bird was back on its own perch at Nanomaga, accompanied by two of the Nuitao birds, which not being at their perch on that island when it was liberated, it had evidently picked up en route. Sixty miles in an hour and a half is probably easy enough for the frigate bird, as in Malayo-Polynesia it is said to have frequently returned a distance of 60 miles in one hour.

It becomes entirely tame and familiar when raised from the nest, and if given liberty returns regulariy to its home perch at night.

\section{THE BOOBIES (Sulu leucogastris) and (Sula sula).}

Both the booby and the red-footed booby are found in the Tortugas, the first usually predominant. They do not breed here at the present time, having probably been exterminated by the fishermen and eggers, who are said to have been particularly fond of the flesh of the young birds. I have never seen them on any of the islands during my six annual visits, but have always found them seated upon the top or crossbar of the channel stakes. They are usually quite shy; so much so that it is very difficult to approach them sufficiently close to secure a photograph. This summer, horrever, we found a booby willing to pose, and a number of rather satisfactory pictures mere secured, some of which are assembled on plate 38 .

Audubon, in volume 3 of his Omithological Biographies, gires a graphic account of a breeding colony of boobies on the Tortugas. From his description one is almost tempted to beliere that in the early part of the past century both the white-bellied and red-footed boobies resorted to these islands for housekeeping, for his description of Booby Island, probably North Key, which has since disappeared, would fit the requirements for a nesting site of the booby, as it agrees well with the character of the nest requirements now used by this species in Cay Verde, Bahamas, the nearest breeding colony. The deseription of the breeding birds on Noddy Key, probably Bush Key of our charts, would indicate the red-footed booby as far as habits are concerned. The nearest place where this species is known to breed at present, is Cayman Brac, about 120 miles off south central Cuba. We will now quote from Audubon's observations of the booby colony at the Tortugas: 
As the Marion was nearing the curious islets of the Tortugas, one of the birds that more particularly attracted my notice was of this species. The nearer we approached land, the more numerous did they become, and I felt delighted with the hope that ere many days should elapse, I should have an opportunity of studying their habits. As night drew her somber curtain over the face of nature, some of these birds alighted on the top-yard of our bark, and I observed ever afterwards that they manifested a propensity to roost at as great a height as possible above the surrounding objects, making choice of the tops of bashes, or even upright poles, and disputing with each other the privilege. The first that was shot at, was approached with considerable difficulty; it had alighted on the prong of a tree which had floated and been fastened to the bottom of a rocky slallow at some distance fron shore; the water was about four feet deep and quite rough; sharks we well knew were abundant around us; but the desire to procure the bird was too strong to be overcome by such obstacles. In an instant, the pllot and myself were over the sides of the boat, and onward we proceeded with our guns cocked and ready. The yawl was well manned, and its crew owaiting the result. After we had struggled through the turbulent waters about a hundred yards, my companion raised his gun and fired; but away flew the bird with a broken leg, and we saw no more of it that day. Next day, however, at the same hour, the Booby was seen perched on the same prong, where, after resting about three hours, it made off to the open sea, doubtless in search of food.

About eight miles to the north-east of the Tortugas Lighthouse, lies a small sand-bar a few acres in extent, called Booby Island, on account of the number of birds of this species that resort to it during the breeding season, and to it we accordingly went. We found it not more than a few feet-above the surface of the water, but covered with Boobles, which lay basking in the sunshine, and pluming themselves. Our attempt to land on the island before the birds should fly off, proved futile, for before we were within fifty yards of it, they had all betaken themselves to flight, and were dispersing in various directions. We landed, however, distributed ourselves in different parts and sent the boat to some distance, the pilot assuring us that the birds would return. And so it happened. As they approached, we laid ourselves as flat as possible in the sand, and although none of them alighted, we attained our object, for in a couple of hours we procured thirty individuals of both sexes and of different ages, finding little difficulty in bringing them down as they flew over us at a moderate height. The wounded birds that fell on the ground made immediately for the water, moving with more ease than I had expected from the accounts usually given of the awkward motions of these birds on the land. Those which reached the water swam off with great buoyancy, and with such rapidity, that it took much rowing to secure some of them while most of those that fell directly into the sea with only a wing broken, escaped. The island was covered with dung, the odour of which extended to a considerable distance leeward. In the evening of the same day we landed on another island, named after the Noddy, and thickly covered with bushes and low trees, to which thousands of that species of Tern resort for the purpose of breeding. There also we found a great number of Boobies. They were perched on the top-branches of the trees, on which they had nests, and here again we obtained as many as we desired. They flew close over our heads, eyeing us with dismay but in silence; indeed, not one of these birds ever emitted a cry, except at the moment when they rose from their perches or from the sand. Their note is harsh and guttural, someiwhat like that of a strangled pig. and resembling the syllables, hork, hork.

The nest of the Booby is placed on the top of a bush at a height of from four to ten feet. It is large and flat, formed of a few dry sticks, covered and 
matted with sea-weeds in greater quantity. I have no doubt that they return to the same nest many years in succession, and repair it as occasion requires. In all the nests which I examined, only one egg was found, and as most of the birds were sitting, and some of the eggs had the chicks nearly ready for exclusion, it is probable that these birds ralse only a single young one like the Common Gannet or Solan Goose. The egg is of a dull white colour, without spots, and about the slze of that of a common hen, but more elongated, being $2 \frac{3}{8}$ inches in length, with a diameter of $1 \frac{3}{4}$. In some nests they were covered with filth from the parent bird, in the manner of the Florida Cormorant. The young, which had an uncouth appearance, were covered with down; the bill and feet of a deep livid blue or indigo colour. On being touched, they emitted no cry, but turned away their heads at every trial. A great quantity of fish lay beneath the trees in a state of putrefaction, proving how abundantly the young birds were supplied by their parents. Indeed, while we were on Noddy Island, there was a constant succession of birds coming in from the sea with food for their young, consisting chiefly of flying-fish and small mullets, which they disgorged in a half macerated state into the open throats of their offspring. Unfortunately the time afforded me on that coast was not sufficient to enable me to trace the progress of their growth. I observed, however, that none of the birds which were still brown had nests, and that they roosted apart, particularly on Booby Island, where also many barren ones usually resorted, to lie on the sand and bask in the sun.

The flight of the Booby is graceful and extremely protracted. They pass swiftly at a height of from twenty yards to a foot or two from the surface, often following the troughs of the waves to a considerable distance, their wings extended at right angles to the body; then, without any apparent effort, raising themselves and allowing the rolling waters to break beneath them, when they tack about, and sweep along in a contrary direction in search of food, much in the manner of the true Petrels. Now, if you follow an individual, you see that it suddenly stops short, plunges headlong into the water, plerces with its powerful beak and secures a fish, emerges again with inconceivable ease, after a short interval rises on wing, performs a few wide circlings, and makes off toward some shore. At this time its flight is different, being performed by flappings for twenty or thirty paces, with alternate sailings of more than double that space. When overloaded with food, they alight on the water, where, if undisturbed, they appear to remain for hours at a time, probably until digestion has afforded them rellef.

The range to whlch this species confines itself along our coast, seldom extends beyond Cape Hatteras to the eastward, but they become more and more numerous the farther south we proceed. They breed abundantly on all such islands or keys as are adapted for the purpose, on the southern and western coasts of the Floridas and in the Gulf of Mexico, where I was told they breed on the sand-bars. Their power of wing seems sufficient to enable them to brave the tempest, while during a continuance of fair weather they venture to a great distance seaward, and I have seen them fully 200 miles from the land.

The expansibility of the gullet of this species enables it to swallow fishes of considerable size, and on such occasions their mouth seems to spread to an unusual width. In the throats of several individuals that were shot as they were returning to their nests, I found mullets measuring seven or elght inches, that must have weighed fully half a pound. Their body beneath the skin, is covered with numerous aircells, which probably assist them in raising or lowering themselves while on wing, and perhaps still more so when on the point of performing the rapid plunge by whlch they secure their prey. 
Their principal enemies during the breeding-season are the American Crow and the Fish Crow, both of which destroy their eggs, and the Turkey Buzzard which devours their young while yet unfledged. They breed during the month of May, but I have not been able to ascertain if they raise more than one brood in the season. The adult birds chase away those which are yet immature during the period of incubation. It would seem that they take several years in attaining their perfect state.

When procured alive, they feed freely, and may be kept any length of time, provided they are supplied with fish. No other food, however, could I tempt them to swallow, excepting slices of turtle, which after all they did not seem to relish. In no instance did I observe one drinking. Some authors have stated that the Frigate Pelican and the Lestris force the Booby to disgorge its food that they may obtain it; but this I have never witnessed. Like the Common Gannet, they may be secured by fastening a fish to a soft plank, and sinking it a few feet beneath the surface of the water, for if they perceive the bait, which they are likely to do if they pass over it, they plunge headlong upon it, and drive their bill into the wood.

When a Booby has alighted on the spar of a vessel, it is no easy matter to catch it, unless it is much fatigued; but if exhausted and asleep, an expert seaman may occasionally secure one. I was informed that after the breeding season these birds roost on trees in company with the Brown Pelican and a species of Tern, Sterna stolida, and spend their hours of daily rest on the sandbanks. Our pilot, who, as I have mentioned in my second volume, was a man of great observation, assured me that while at Vera Cruz, he saw the fishermen there go to sea, and return from considerable distances, simply by following the course of the Boobies.

The bills and legs of those which I procured in the brown plumage, and which were from one to two years of age, were dusky blue. These were undergoing moult on the 14th of May. At a more advanced age, the parts mentioned become paler, and when the bird has arrived at maturity, are as represented in my plate. I observed no external difference between the sexes in the adult birds. The stomach is a long dilatable pouch, thin, and of a yellow colour. The body is muscular, and the flesh, which is of a dark colour, tough, and having a disagreeable smell, is scarcely fit for food.

I am unable to find a good reason for those who have chosen to call these birds boobies. Authors, it is true, generally represent them as extremely stupid; but to me the word is utterly inapplicable to any bird with which I am acquainted. The Woodcock, too, is said to be stupid as are many other birds; but my opinion, founded on pretty extensive observation, is, that it is only when birds of any species are unacquainted with man, that they manifest that kind of ignorance or innocence which he calls stupidity, and by which they suffer themselves to be imposed upon. A little acqualntance with him soon enables them to perceive enough of his character to induce them to keep aloof. This I observed in the Booby Gannet, as well as in the Noddy Tern, and in certain species of land birds of which I have already spoken. After my first visit to Booby Island in the Tortugas, the Gannets had already become very shy and wary, and before the Marion sailed away from those peaceful retreats of the wandering sea-birds, the Boobies had become so knowing, that the most expert of our party could not get within shot of them.

The Tortugas are used as a stepping-stone by many of the lesser migratory birds that winter in the West Indies and even farther south. In the northward journey in spring and the southward flight 
in autumn, these birds rest here for a varying length of time before continuing their travels. These migratory land birds always show the effect of their stay on these keys, for most of them look entirely different from the trim little creatures which we are accustomed to see on the mainland. The little warblers and even the bobolinks are all fluffed up and ragged and their appearance and motion suggest "the dim gray dawn of the morning after," the after effect of a "night out." They are lacking in shyness and appear quite as careless about their safety as they do about their appearance.

The eagerness with which they take to a pan of fresh water or the dripping of a leaky storage tank leads me to believe that it is the want of fresh water that is responsible for this change of habit. The only regular supply of fresh water that these birds can obtain on any of the keys are the droplets of dew in the early morning hours and that furnished by an occasional shower. This, then, means a full drink and bath in the early morning and a long thirst through the rest of the hot day. The bathing is rather an interesting function under these circumstances. A bird will rest on a clump of 'sparkling leaflets, beating his wings against them and thereby accumulating sufficient moisture in the course of time to become thoroughly washed. The vireos and flycatchers plunge against the moist foliage, while the swallows merely graze it as they pass by.

No small land birds breed upon the Tortugas, and it has been held that the lack of fresh water is responsible for this. This explanation alone does not appeal to me, for I know of no exposed fresh water upon any of the keys between Miami and the Tortugas, and yet most of them support several or more species of breeding land birds. It seems more likely that the character of the vegetation and its associated insect fauna is more to their liking on some of the other keys, for the predominant floral element in the Tortugas is bay cedar, a plant that forms a scarcely notable feature in the key flora farther north.

Believing that a list of all the birds so far reported from the Tortugas will not be without interest to the reader, I will close this article with it.

In preparing this list I have consulted the registers in the division of birds of the United States National Museum to see what specimens the national collection contains from the Tortugas. Here I found quite a large series of early records made between 1857 and 1864 , which appear in the following list in the columns headed by these numbers.

The 1857 column represents birds collected by G. Würdemann while connected with the Coast and Geodetic Survey.

The 1859 column represents specimens collected by Capt. D. P. Woodbury. 
The 1859-60 column shows specimens collected by Dr. J. B. Holder, while the 1860 and 1864 columns refer to additional lots of birds donated by Capt. D. P. Woodbury.

In the 1859 column the * followed by a 1 refers to a specimen donated by Jos. C. Clapp, while the one in the 1860 column marked * 1 denotes a specimen donated by Geo. Phillips.

The remaining columns refer to published records from the Tortugas. These are:

The sixth column includes the birds observed during parts of March and April, 1890, by W. E. D. Scott, as reported in the "Auk," vol. VII, no. 4, pp. 301-314, 1890. The records of 1913, 1914, 1915, 1916 , and 1917 were made by the author, and were published as follows:

1913. Yearbook No. 12, Carnegie Institution of Washington, pp. 172-175, "Birds observed on the Florida Keys on April 25 to May 9, 1913."

1914. Yearbook No. 13, Carnegie Institution of Washington, pp. 192-195, "Birds observed on the Florida keys from April 20 to April 30, 1915."

1915. Yearbook No. 14, Carnegie Institution of Washington, pp. 197-199, "Birds observed on the Florida Keys and along the railroad of the mainland from Key Largo to Miami, June 17 to July 1, 1915."

1916. Yearbook No. 15, Carnegie Institution of Washington, pp. 182-188, "Birds observed in 1916 in the region of Miami and the Florida Keys from May 15 to June 4, and along the railroad from Key West to Miami on June 24."

1916. Yearbook No. 15, Carnegie Institution of Washington, pp. 170-173, "Fifth annual list of birds observed on the Florida Keys (1917)."

An asterisk indicates that the bird was observed in that year.

The gull-billed tern is reported under the name Sterna nuttalli by Nuttall in his Manual of Ornithology of the United States and Canada, Water Birds page 279, 1834, from the Tortugas.

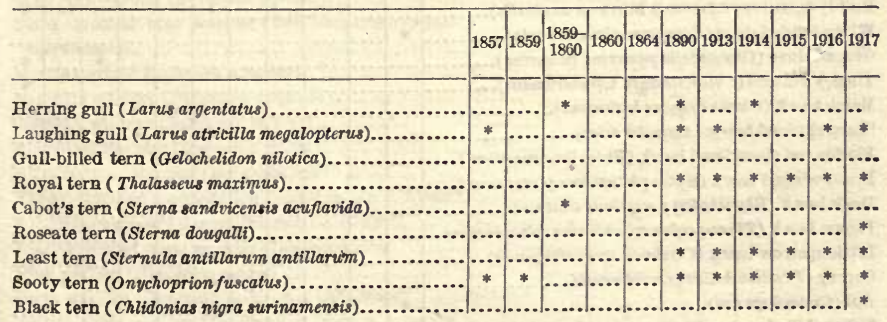




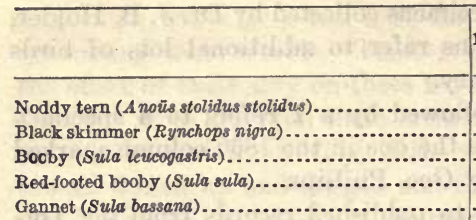

Anhinga (A nhinga ankinga).

Florida cormorant(Phalacrocorax auritus floridanus)

Brown pelican (Pelocanus occidentalis)

Man-o'-war bird (Fregata magnificens rothschildi).

Mallard (Anas platyrhynchos).

Snow goose (Chen hyperboreus hyperboreus)

Blue goose (Chen caerulescens)

Glossy lbis (Plegadis autumnalis).

American bittern (Botaurus lentiginosus)

Ward's heron (Ardea herodias wardi).

American egret (Herodias egretta).

Snowy egret (Egretta candidissima candidissima)

Reddish egret (Dichromanassa rufescens).

Louisiana heron (Hydranassa tricolor ruficollis).

Little blue heron (Florida cacrulea caerulea)

Green heron (Butorides virescens virescens).

Black-crowned night heron (Nycticorax nycticorax naevius).

Yellow-crowned night heron (Nyctanassa violacea).

Limplin (A ramus vociferus)

Virginia rail (Rallus virginianus).

Sora rail (Porzana carolina)

Black rail (Creciscus jamaicensis)

Purple gallinule (Ionornis martinicus).

Florida gallinule (Gallinula chloropus cachinnans).

Wilson's snipe (Gallinago delicata).

Least sandpiper (Pisobia minutilla)

Semipalmated sandpiper (Ereunetes pusillus).

Sanderling (Calidris alba)

Willet (Catoptrophorus semipalmatus semipalmatus).

Upland plover (Bartramia longicauda)

Spotted sandpiper (Actitis macularia)

Black-bellied plover (Squatarola squatarola).

Semipalmated plover (Charadrius semipalmatus)..

Belted piping plover (Charadrius melodus).

Wilson's plover (Pagolla wilsonia wilsonia).

Ruddy turnstone (A renaria interpres morinella)

White-headed dove (Patagicenas leucocephala).

Ground dove (Chrmepelia passerina passerina)

Turkey vulture (Cathartes aura scptentrionalis)

Marsh bawk (Circus cyaneus hudronius)

Sharp-shinned hawk (A ccipiter velox).

Florida red-shouldered hawk (Buteo lineatus alleni).

Broad-winged hawk (Buteo platypterus platypterus).

Duck hawk (Rhynchodon peregrinus anatum)

Pigeon hawk (Tinnunculus columbarius columbarius)

Little sparrow hawk (Cerchneis sparveria paula).

Osprey (Pandion halizetus carolinensis).

Ani (Crotophaga ani).

Yellow-bllled cuckoo (Coccyzus americanus a mericanus).

Black-billed cuckoo (Coccyzus erythropthalmus). 


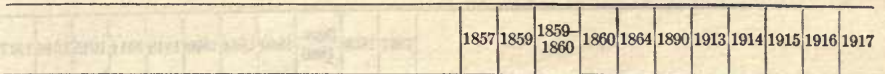

Belted kingfisher (Streptoceryle alcyon alcyon). Ivory-billed woodpecker (Campephilus principalis). Yellow-bellied sapsucker (Sphyrapicus varius varius). Chuck-will's-widow (Antrostomus carolinensis).

Night hawk (Chordeiles minor minor). Night hawk (subspecies) (Chordeiles minor chapmani)?. Ruby-throated hummer (Archilochus colubris). Kingbird (Tyrannus tyrannus) Gray kingbird (Tyrannus dominicensis dominicensis) Phoebe (Sayornis phoebe)

Wood pewee (Myiochanes virens).

Florida crow (Corvus brachyrhynchos pascuus) Bobolink (Dolichonyx oryzisorus). Bahama red-winged blackbird (Agelaius phoniceus bryanti).

Orchard oriole (Icterus spurius).

Baltimore oriole (Icterus galbula)

Goldfinch (Astragalinus tristis tristis)

Savanna sparrow (Passerculus sandwichensis savanna). Grasshopper sparrow (A mmodramus savannarum australis)

Rose-breasted grosberk (Zamelodia ludoviciana) Scarlet tanager (Piranga erythromelas). Summer tanager ( $P$ iranga rubra $r u b r a$ ). Cuban cliff swallow (Petrochelidon fulva fulva) Barn swallow (Hirundo rustica erythrogastris). White-bellied swallow (Iridoprocne bicolor). Bahaman swallow (Callichelidon cyaneoviridis) Cedarbird (Bombycilla cedrorum) Black-whiskered vireo (Vireosylva calidris barbatula).. Red-eyed vireo ( Vireosylva olivacea)

Yellow-throated vireo (Lanivireo flavifrons). White-yed vireo (Vireo griseus griseus)... Black and white creeping warbler (Mniotilta varia) Prothonotary warbler (Protonotaria citrea).

Swainson's warbler (Limnothlypis swainsonii) Worm-eating warbler (Helmitherus vermivorus) Bachman's warbler (Vermivora bachmani). Blue-winged warbler (Vermivora pinus) Parula warbler (Compsothlypis americana americana) Cape May warbler (Dendroica tigrina).. Black-throated blue warbler (Dendroica caerulescens cacrulescens).......

Myrtle warbler Dendroica coronata).

Magnolia warbler (Dendroica magnolia)

Cerulean warbler (Dendroica cerulea).

Black-poll warblor (Dendroica striata)

Blackburnian warbler (Dendroica fusca)

Yellow-throated warbler (Dendroica dominica dominica) Sycamore warbler (Dendroica dominica albilora). Black-throated green warbler (Dendroica virens). Pine warbler (Dendroica vigorsi).

Palm warbler (Dendroica palmarum palmarum)

Yellow-palm warbler (Dendroica palmarum hypochrysea)

Prairie warbler (Dendroica discolor)

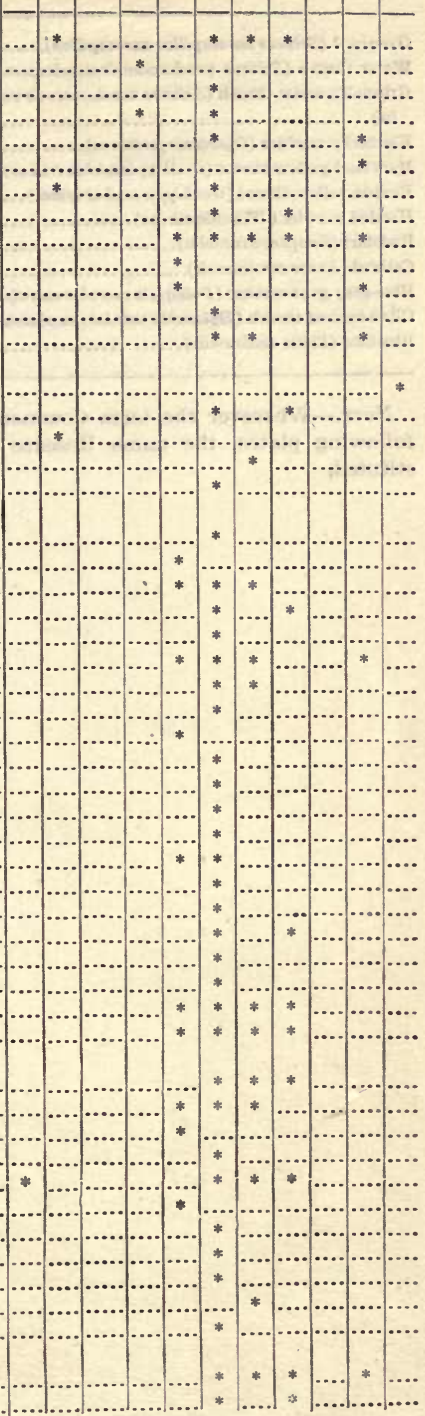




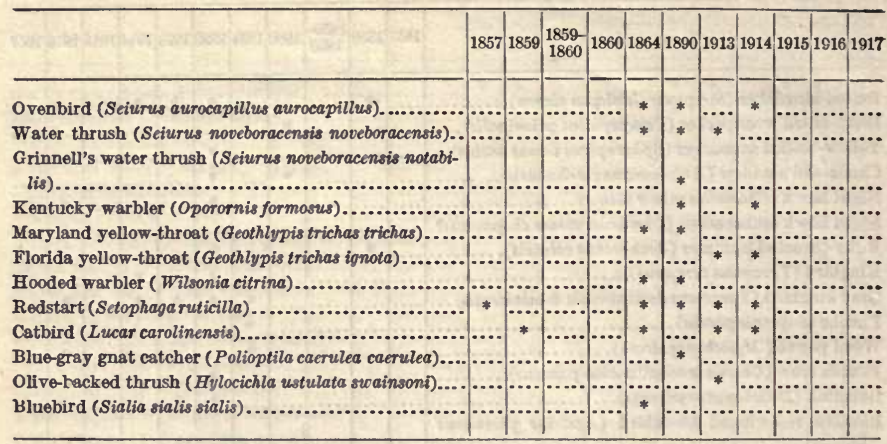

Note.-Wherever the term Common Tern (Sterna hirundo) appears on the following plates, the name Roseate Tern (Sterna dougalli) should be substituted. 




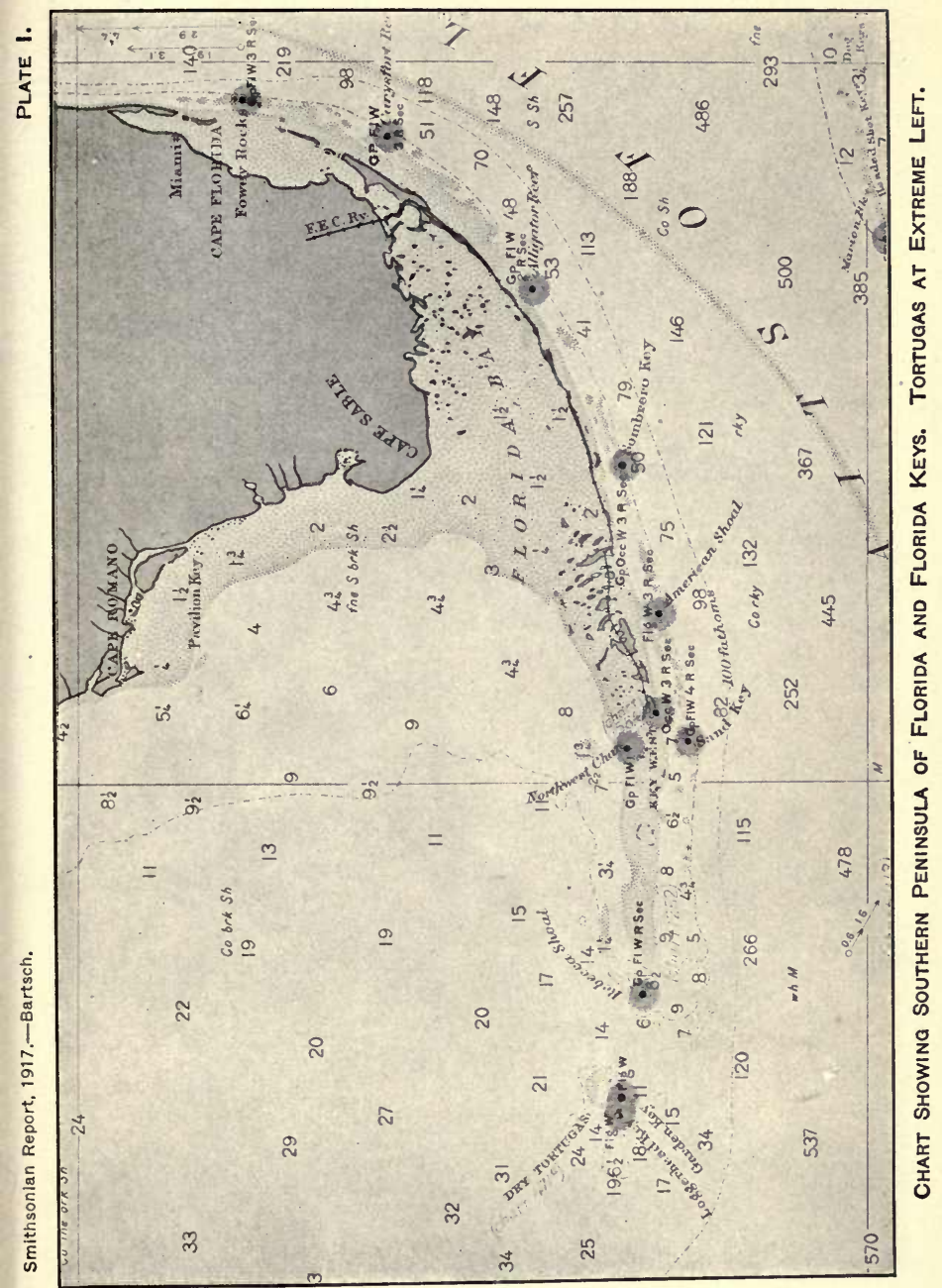




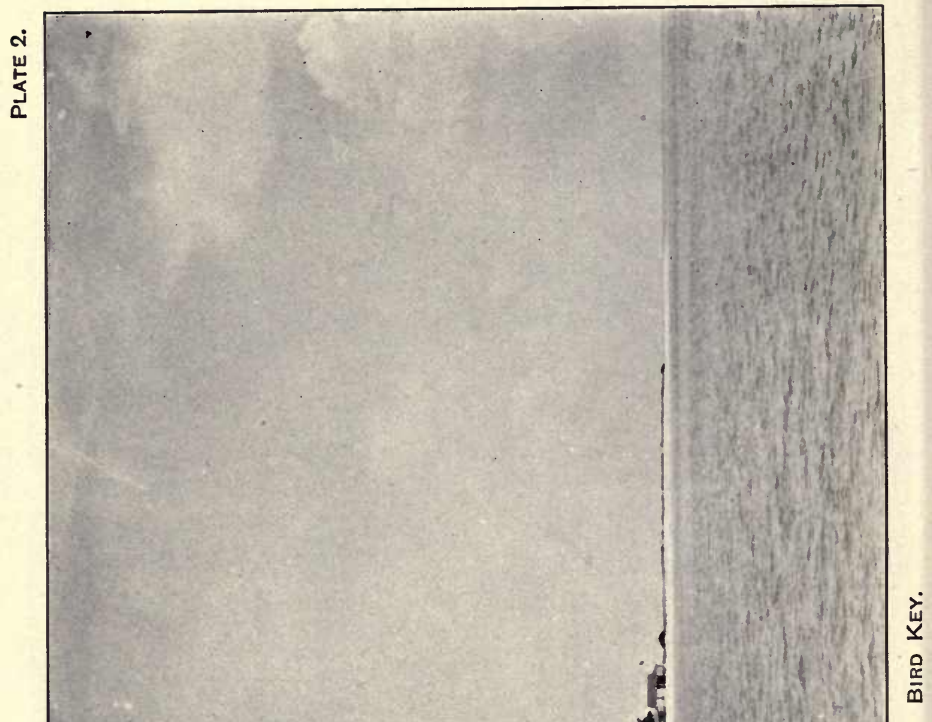

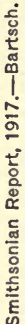




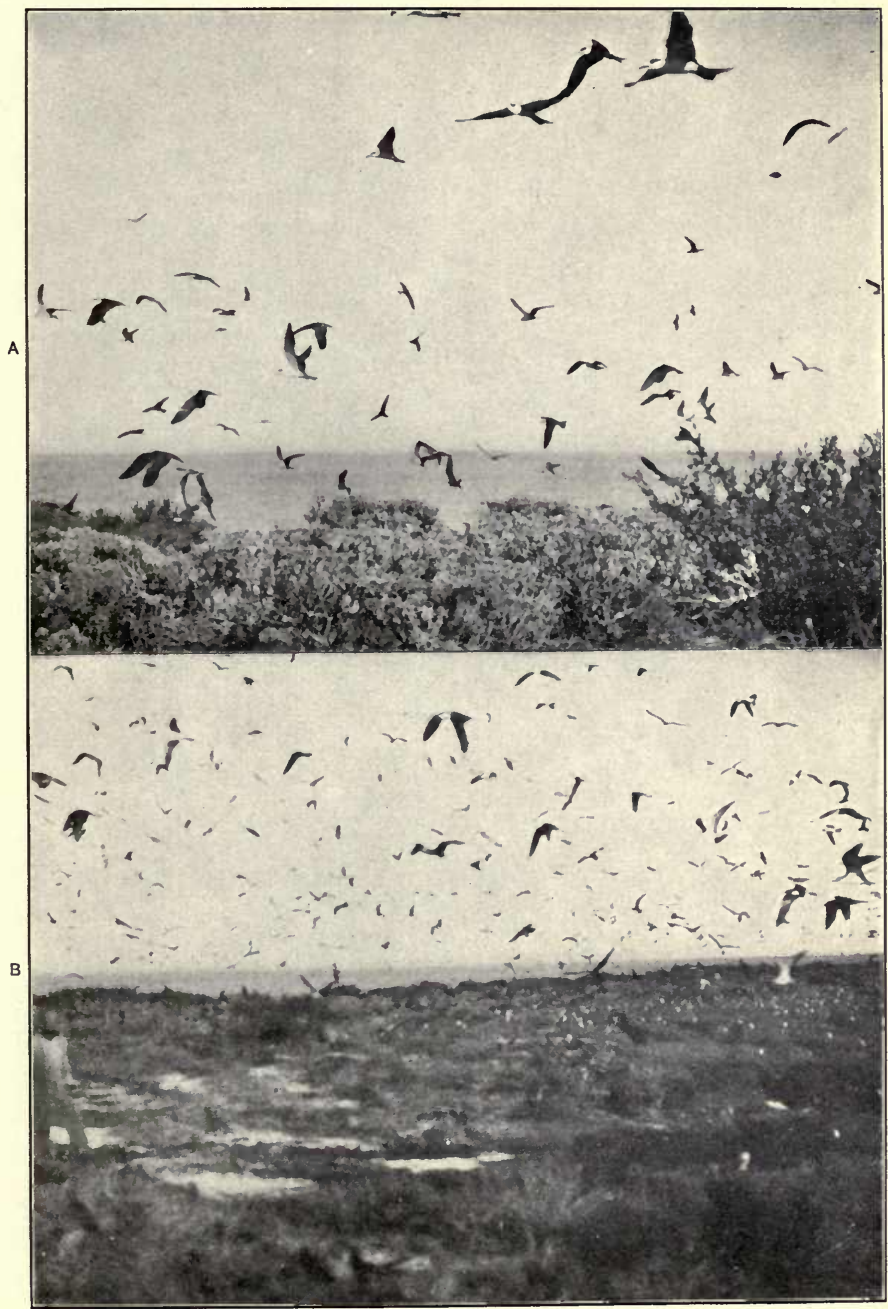

Characteristic Tern activities on Bird Key.

A, looks northeast; B, southwest from center of island. 


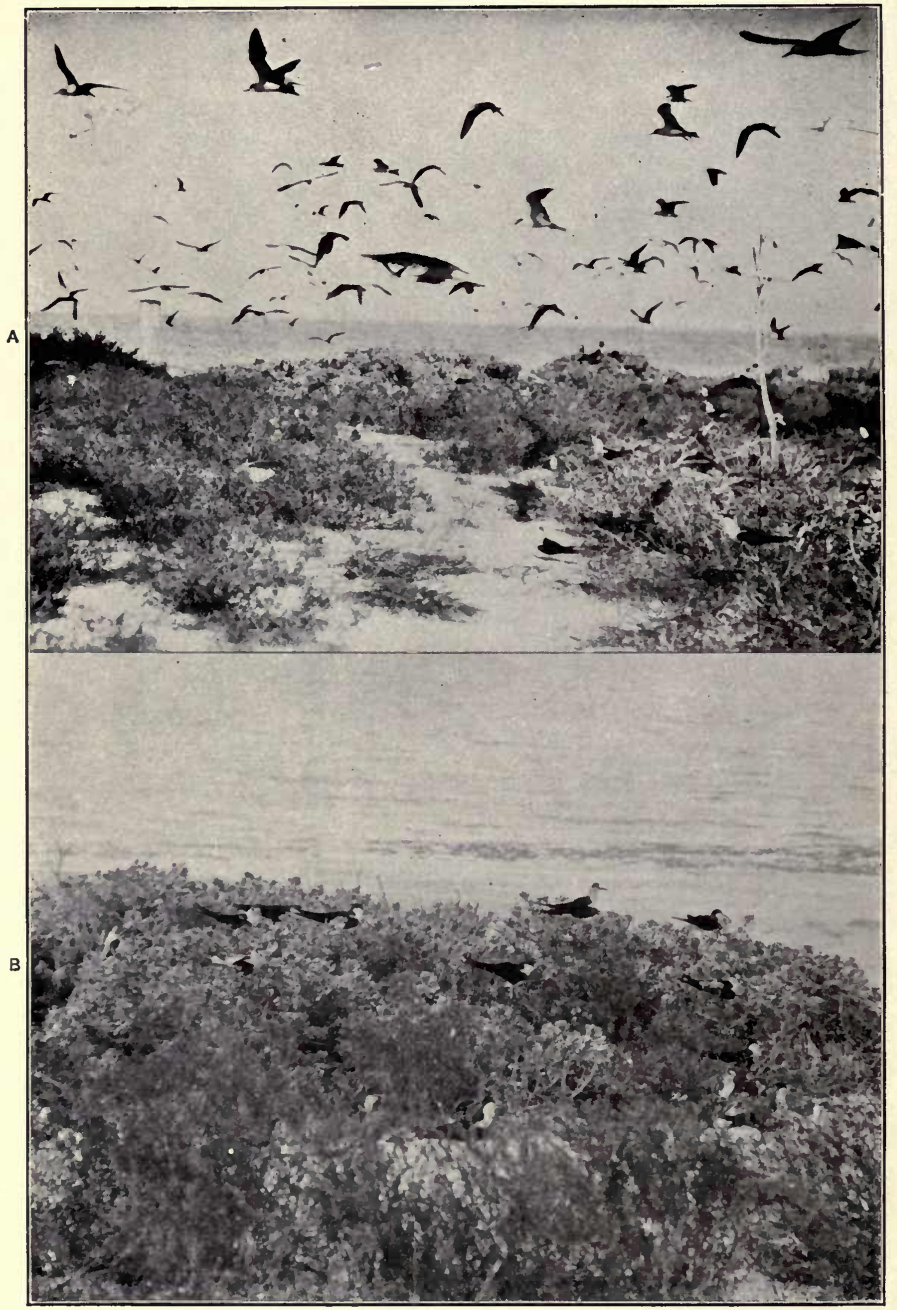

A. General View looking northwest from Center of Bird Key. B. SOOTY TERNS RESTING UPON TOPS OF BAY CEDARS, A RATHER UNCOMMON PRACTICE. 


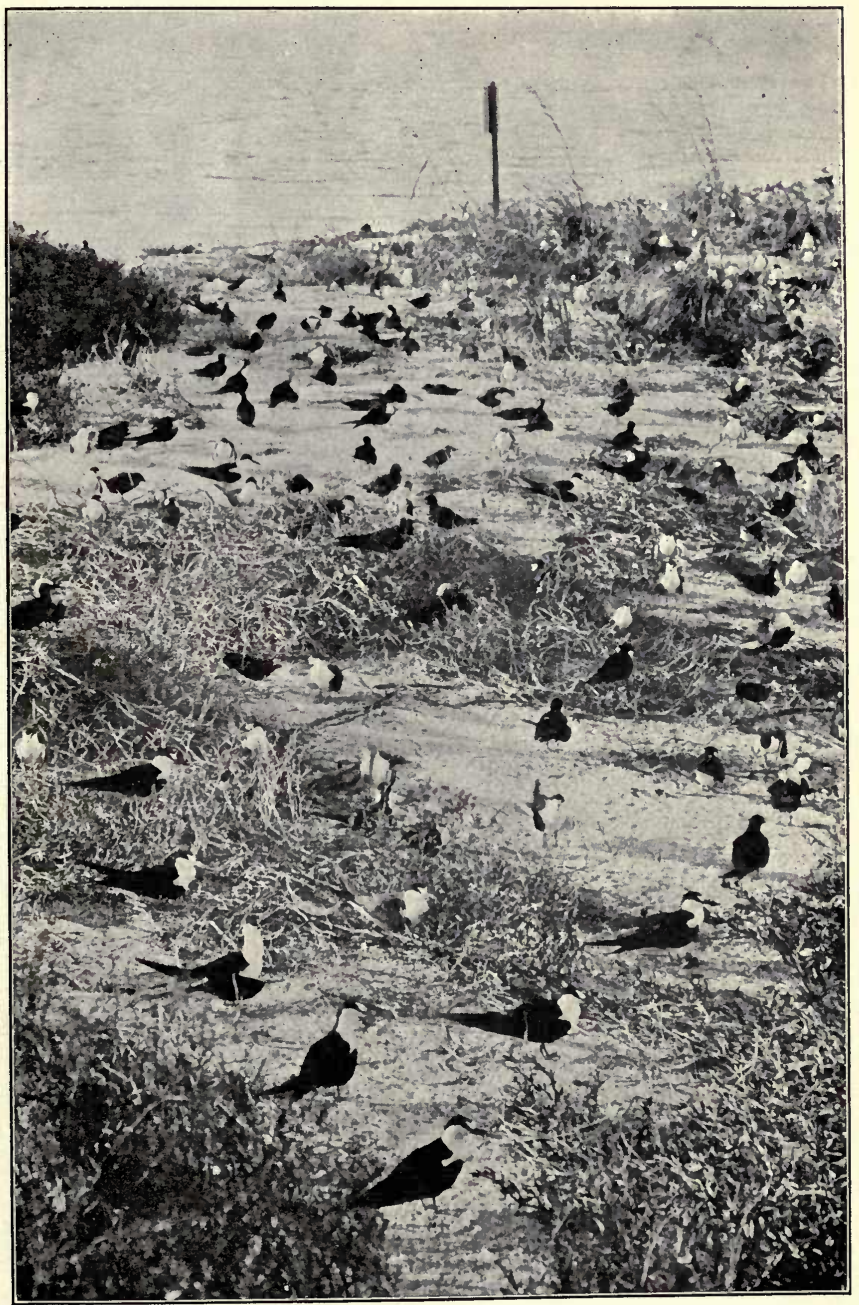

Open Grounds NorthWEst of the House on Bird Key, SHOWING Close DISTRIBUTION OF SOOTIES AND THEIR YOUNG. 


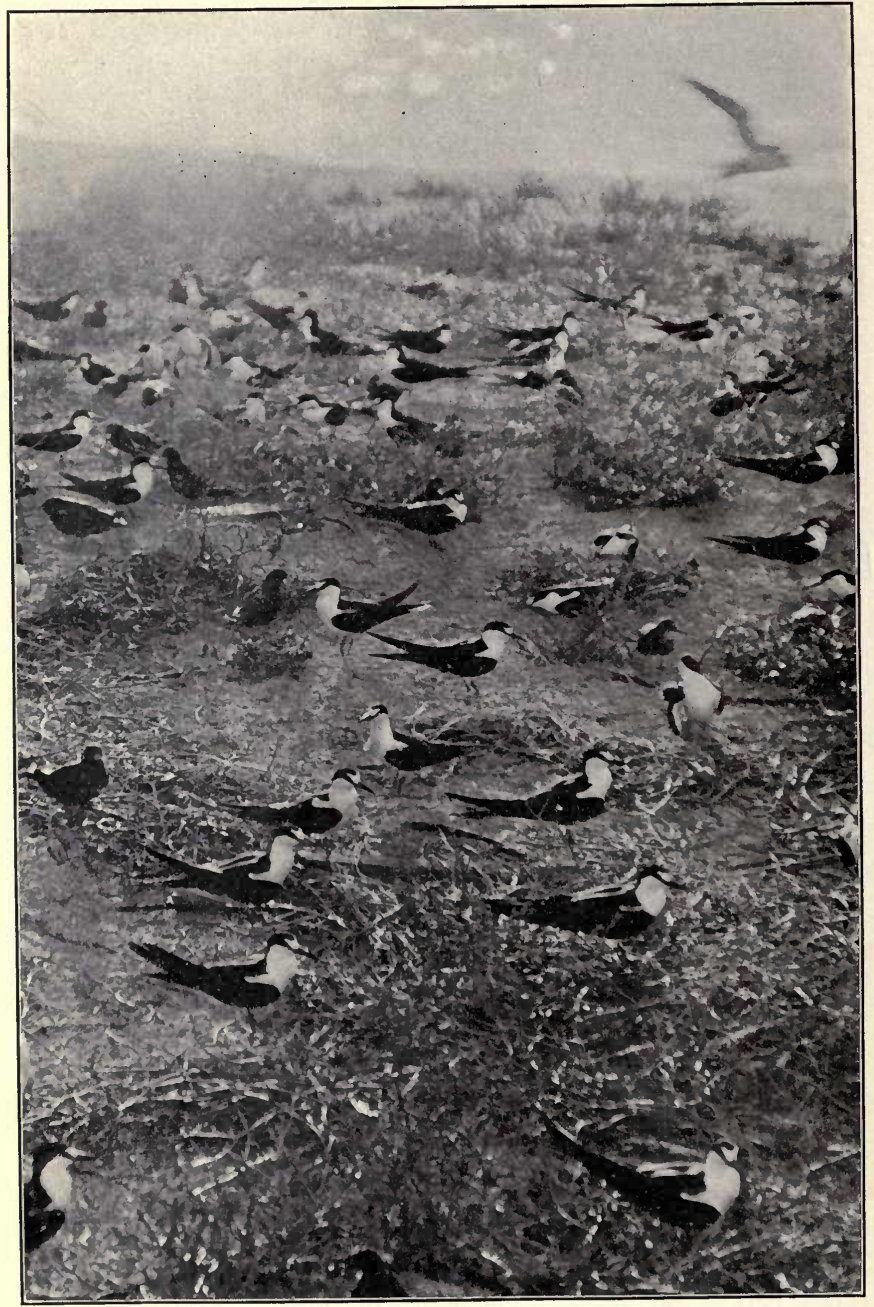

Bird Key LOOKING NorthWARd from the HOUSE, Showing General DISPOSITION OF SOOTY TERNS IN OPEN REACHES. 


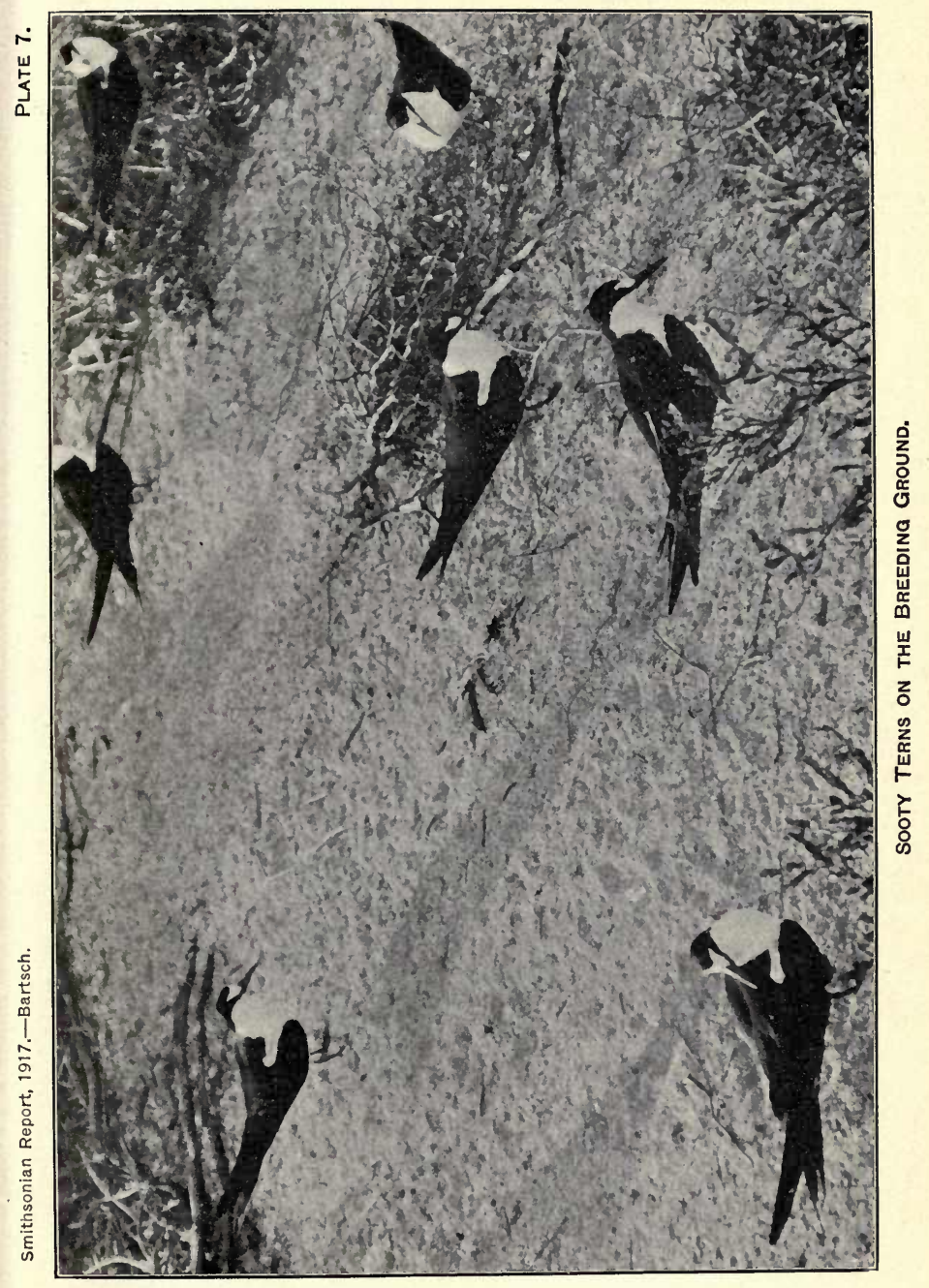




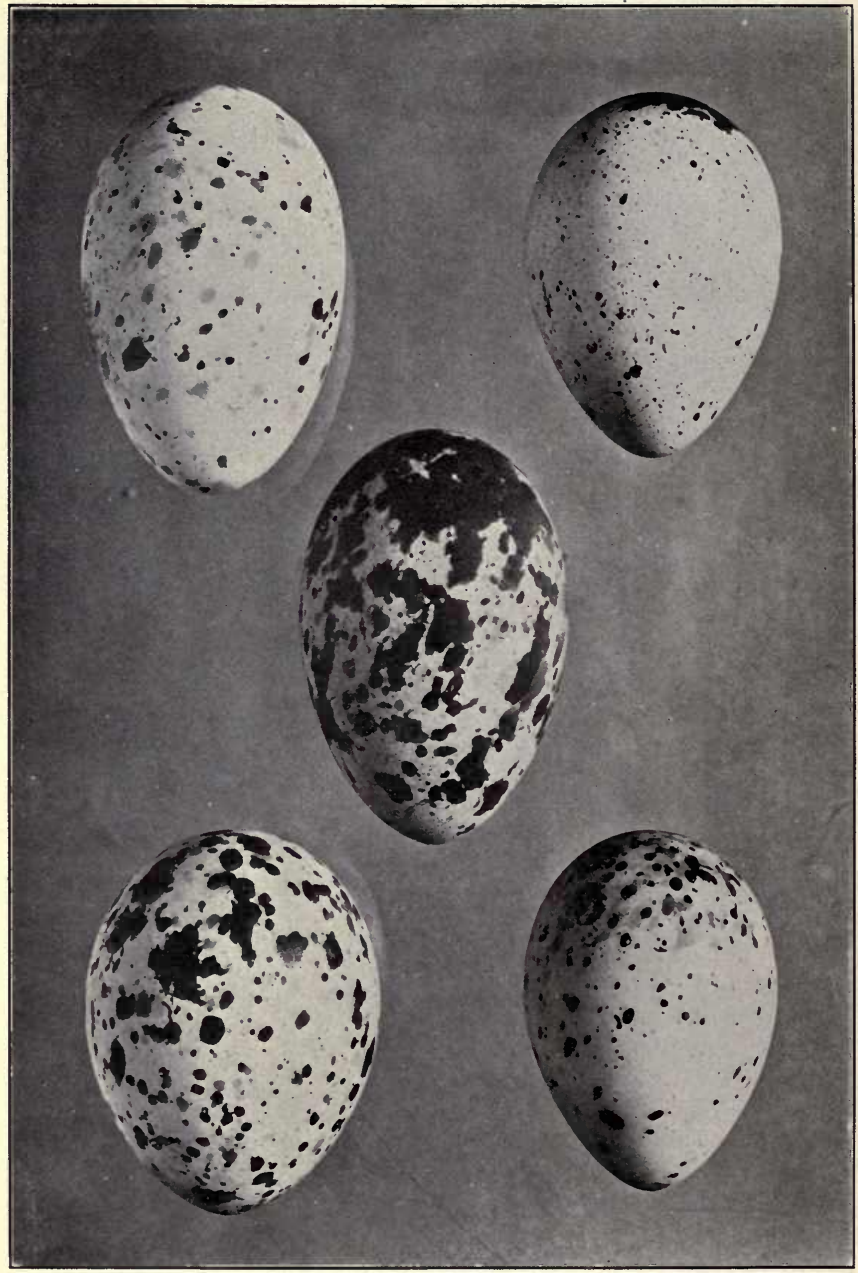

Five Eggs of the Sooty TERn, Showing Range of Variation in Markings. Natural size. 


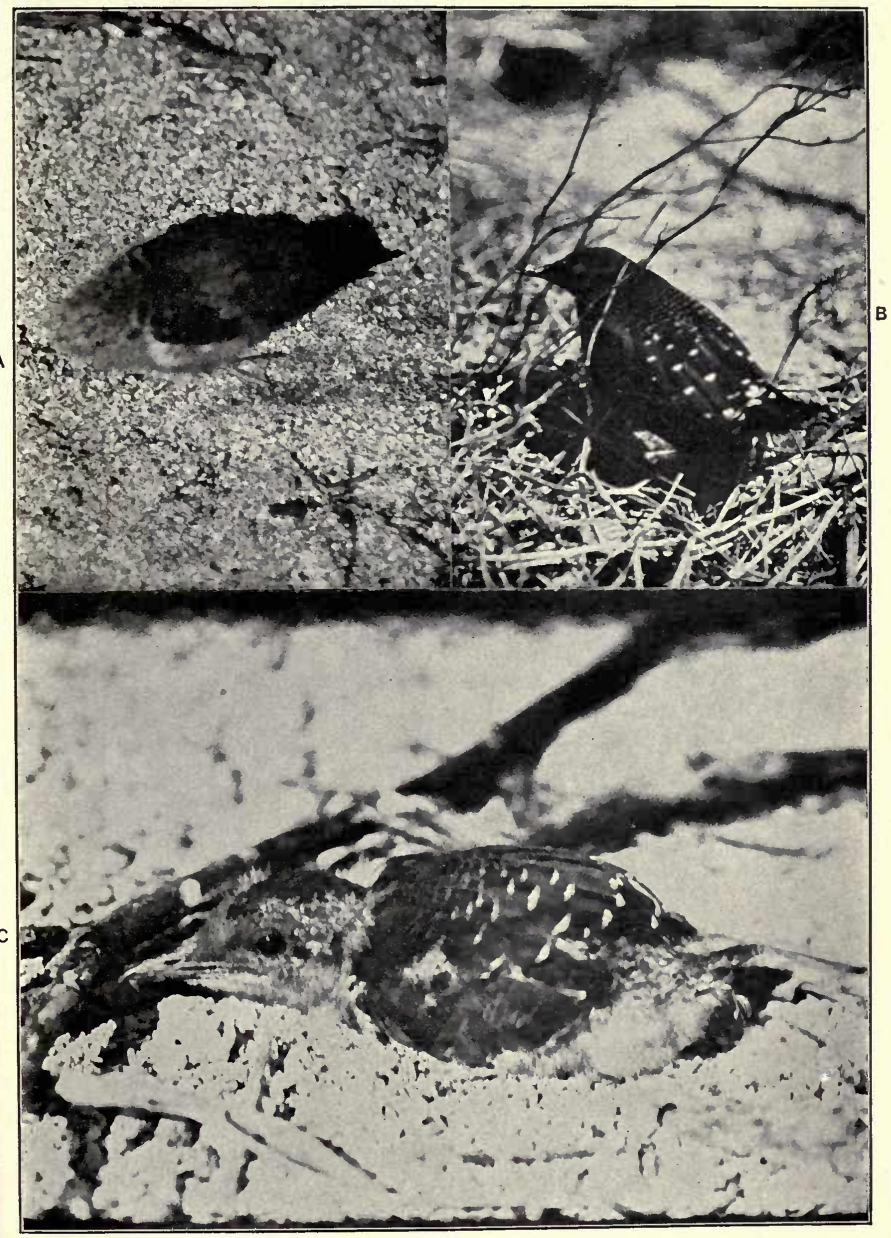

Three Young Sooty Terns Showing DeVelopmental Stages.

$\Lambda$, about 1 week old; $B$, more than 1 month old; C, about 25 days old. 


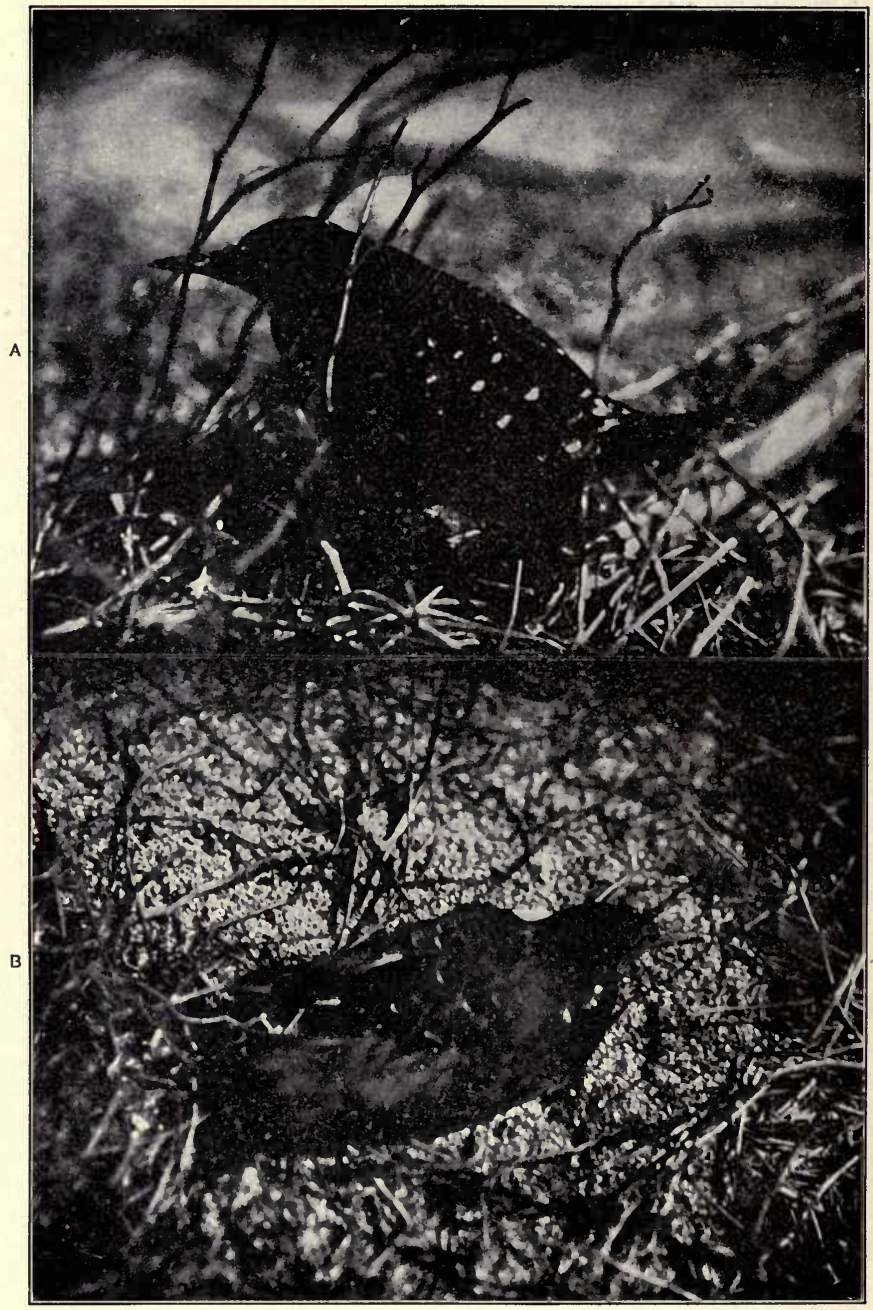

YOUNG SOOTY TERNS.

A. Bird old enough to try its wings. B. Bird just prior to beginning to fly. 


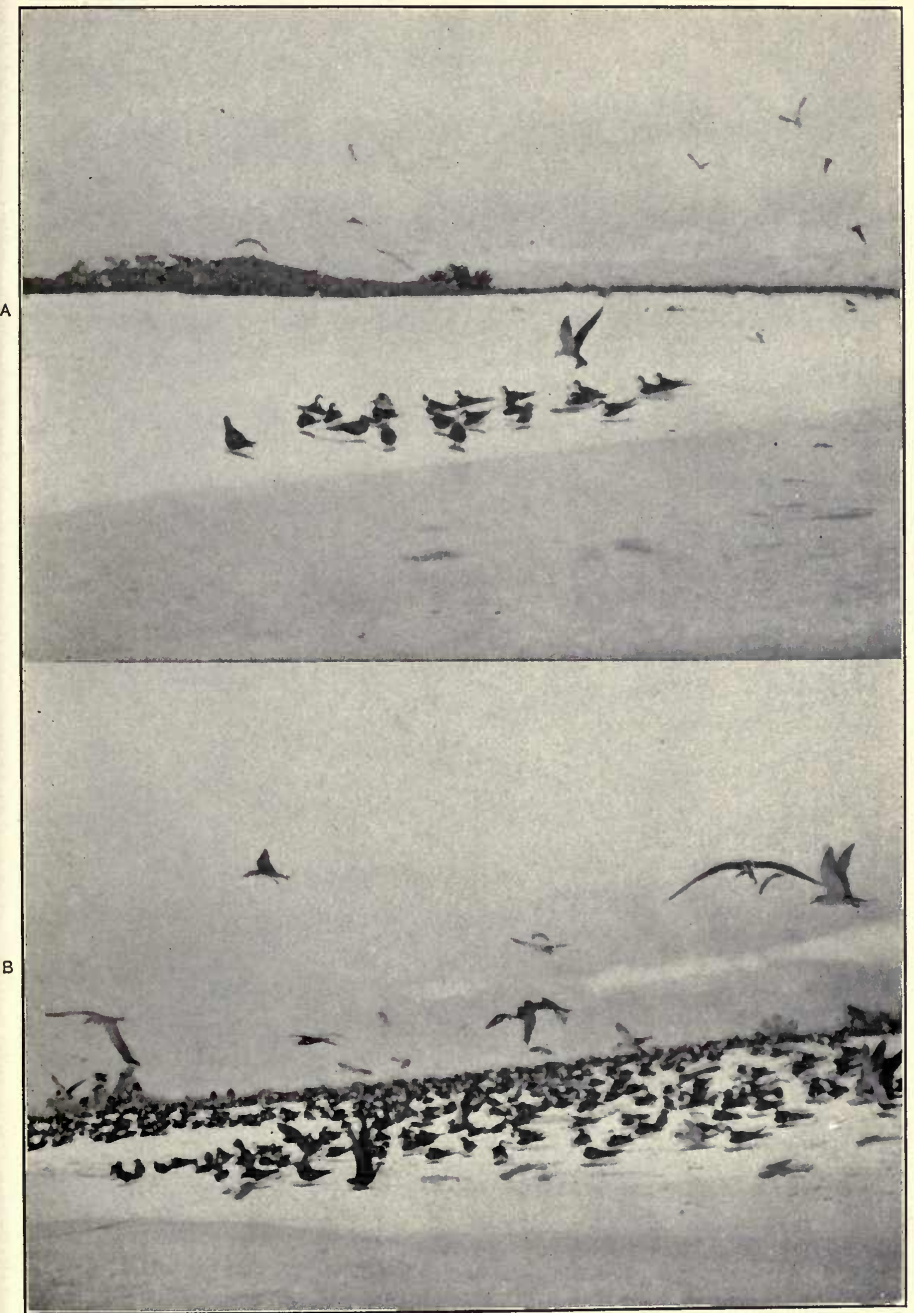

A. Group of AdULt Sooty and Noddy Terns SunNing THEMSELVES ON THE BEACH. B. OLD AND YOUNG OF BOTH THE SOOTY AND NODDY TERN ENJOYING A SUN BATH ON THE GLARING, HOT, WHITE SAND. 
Smithsonian Report, 1917.-Bartsch.

PLATE 12.

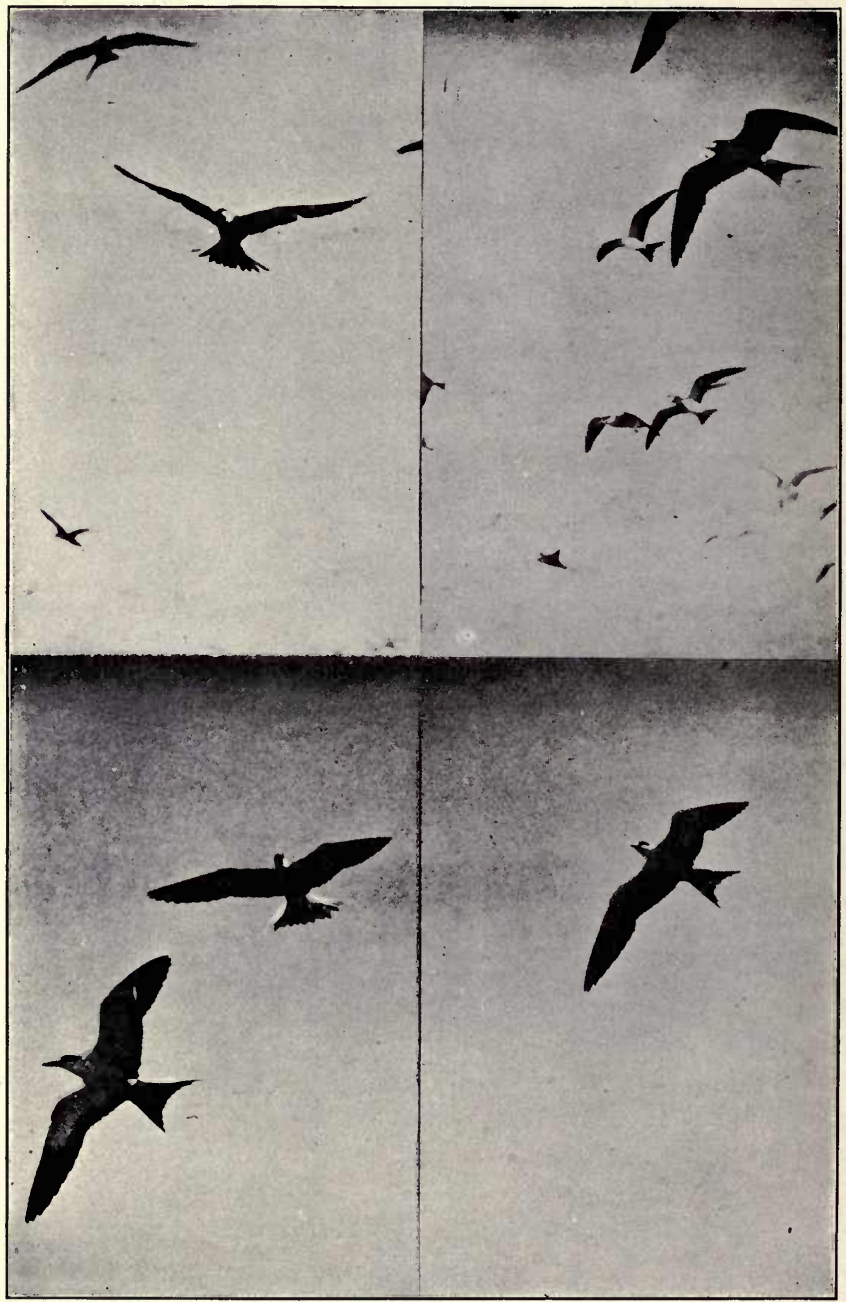

instantaneous Pictures Showing Poses Assumed by Sooty Terns on WING. 


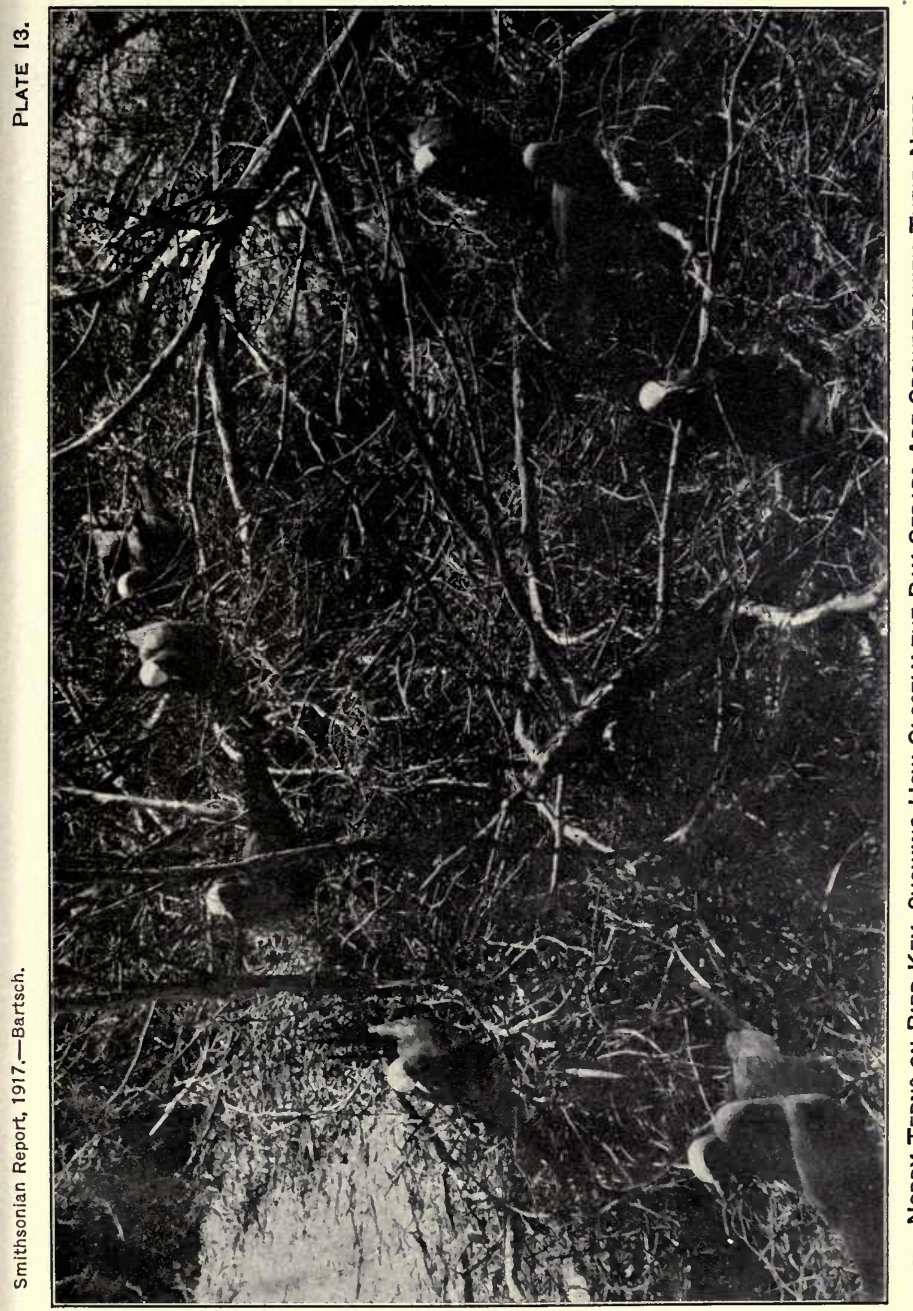




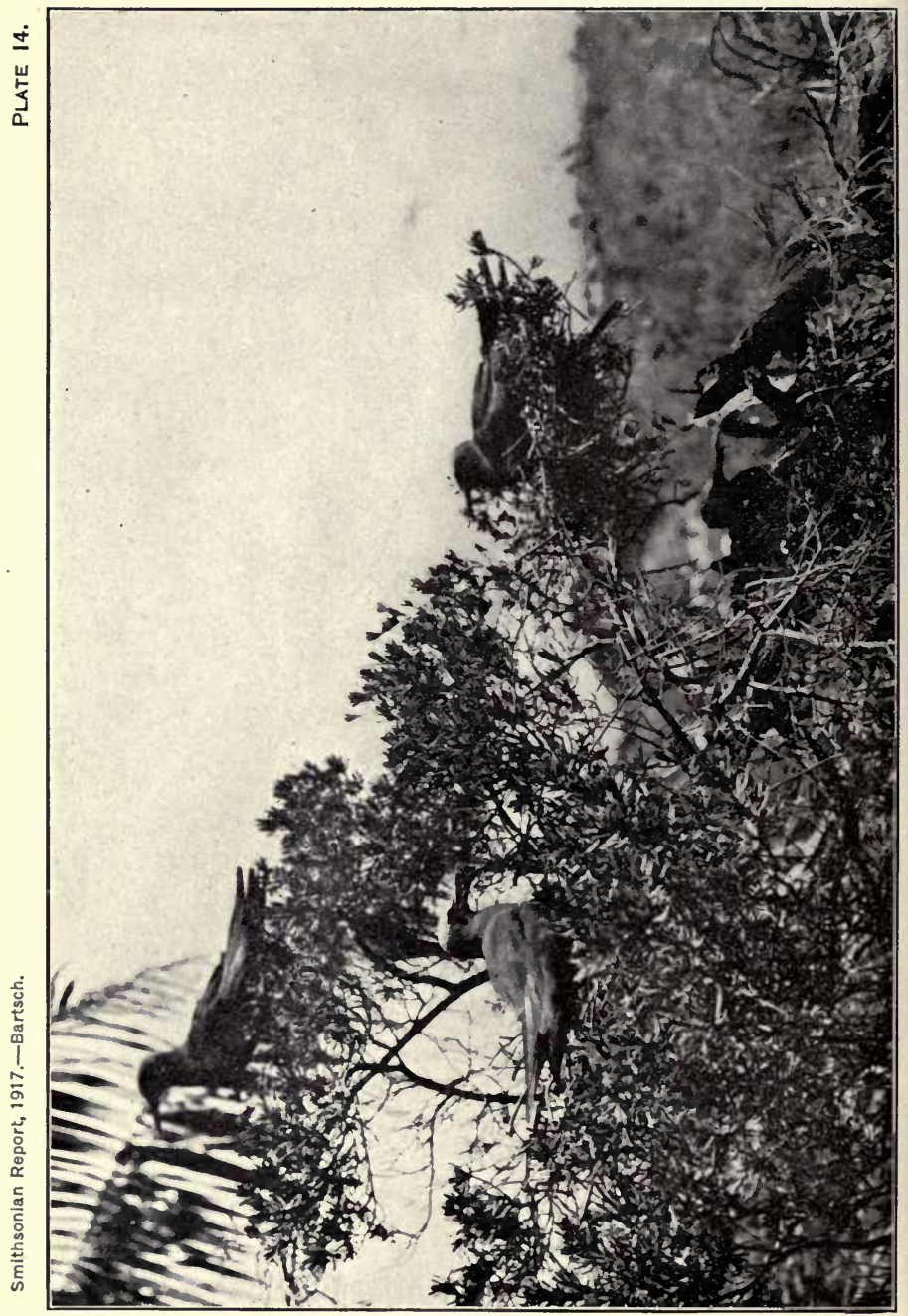

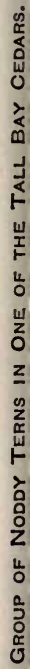


Plate 15.

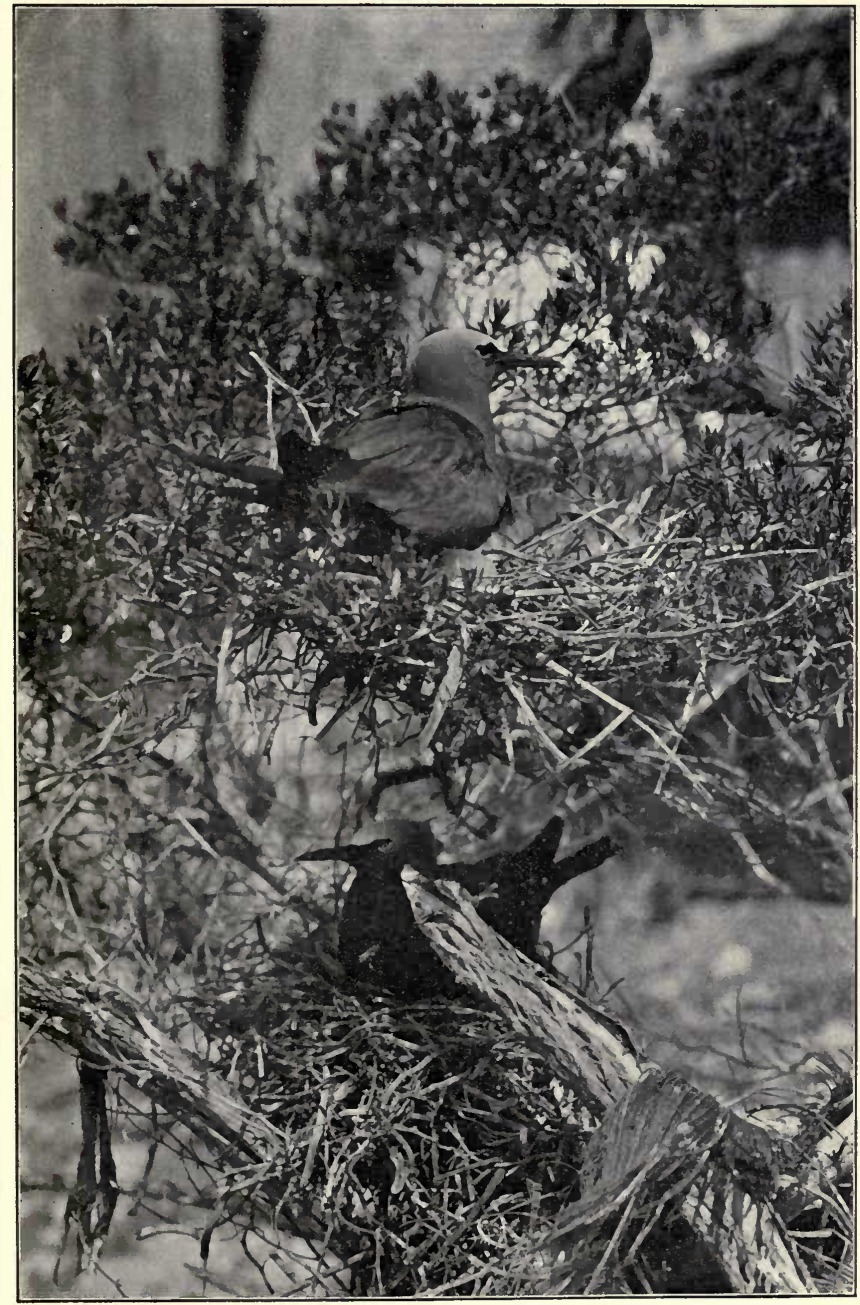

Near View of Two Noddies on Their Nests. 


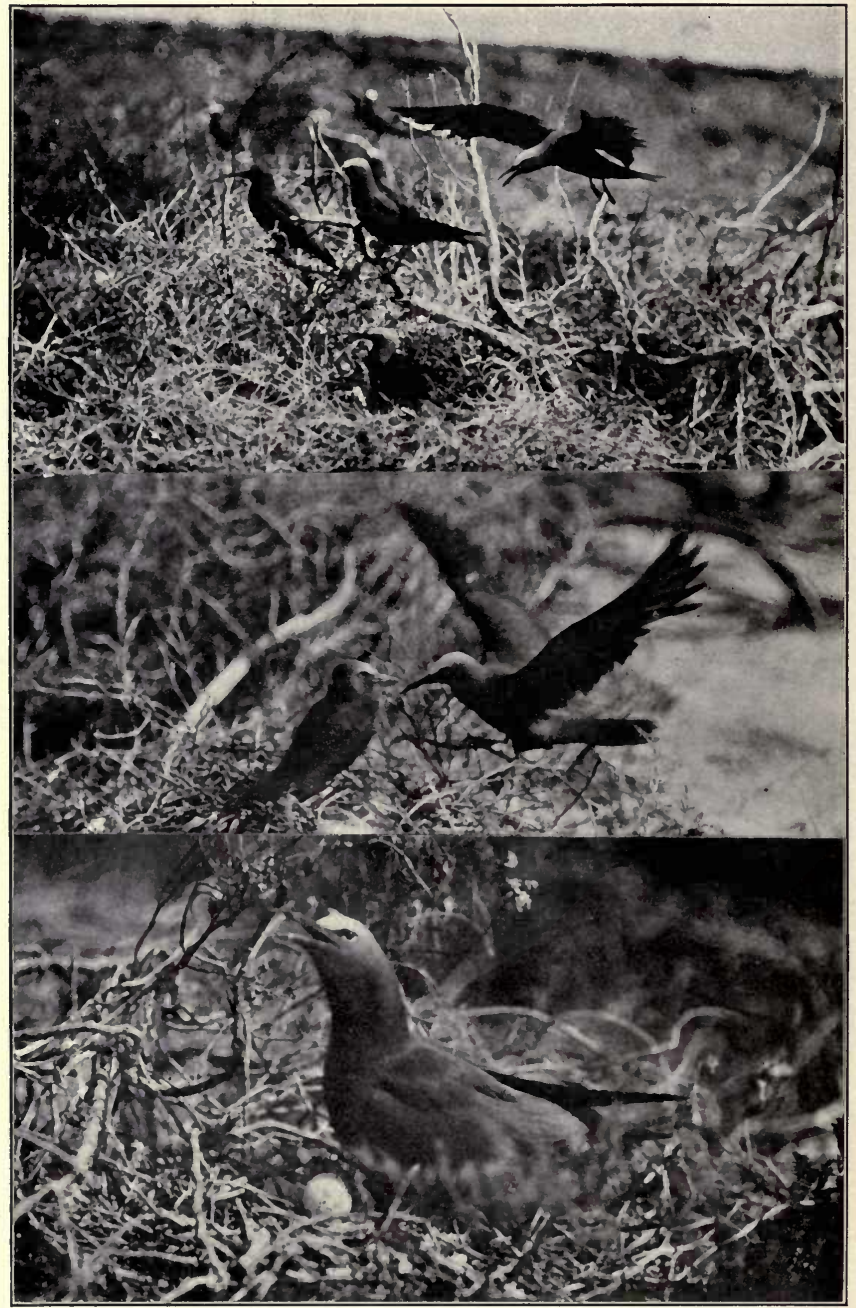

Noddy Terns About Their Nests, Showing Characteristic Attitudes. The Young BiRd IN THE MIdDLE PICTURE IS ALMOST REAdY to Fly. 
Smithsonian Report, 1917.-Bartsch.

Plate 17.

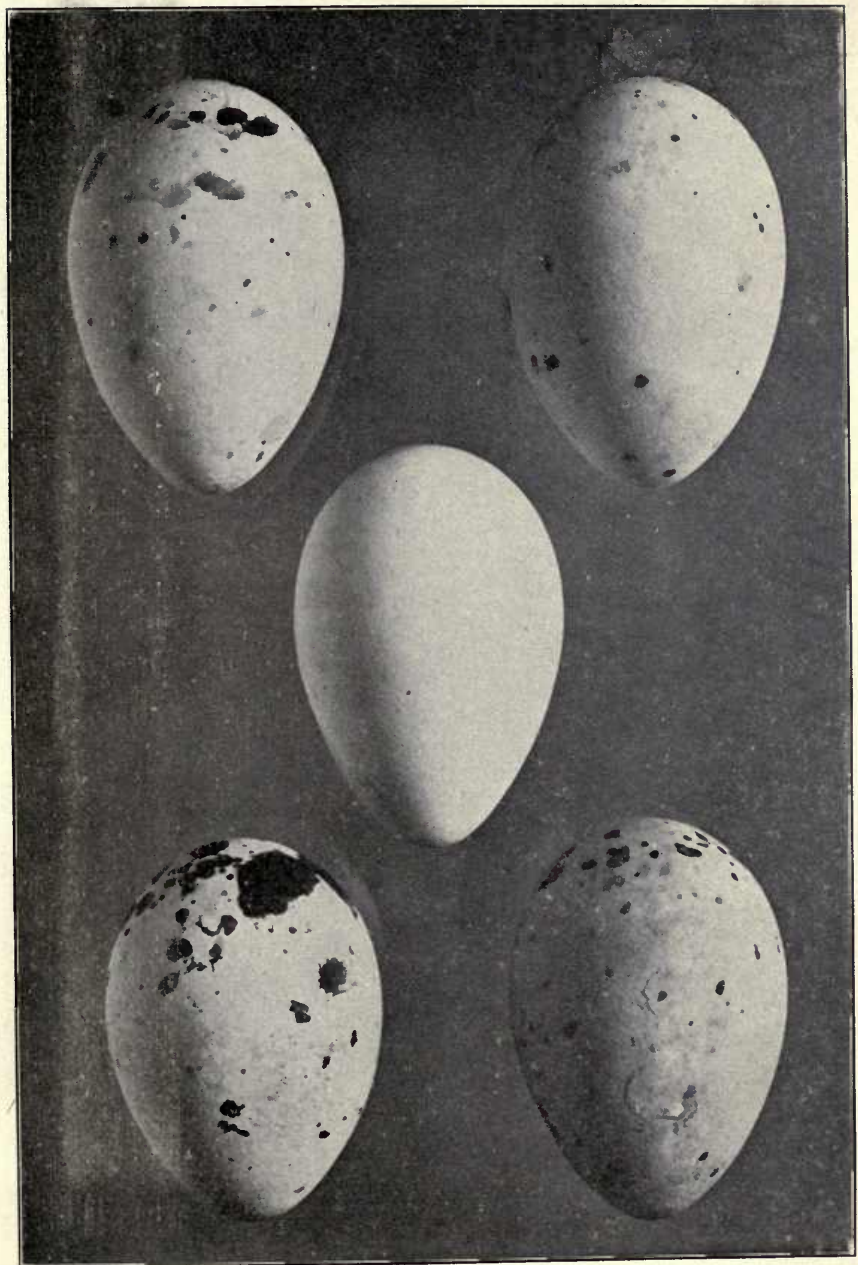

EgGs of the NOddy TERn SHOWING Range of Variation IN Markings. Natural size. 


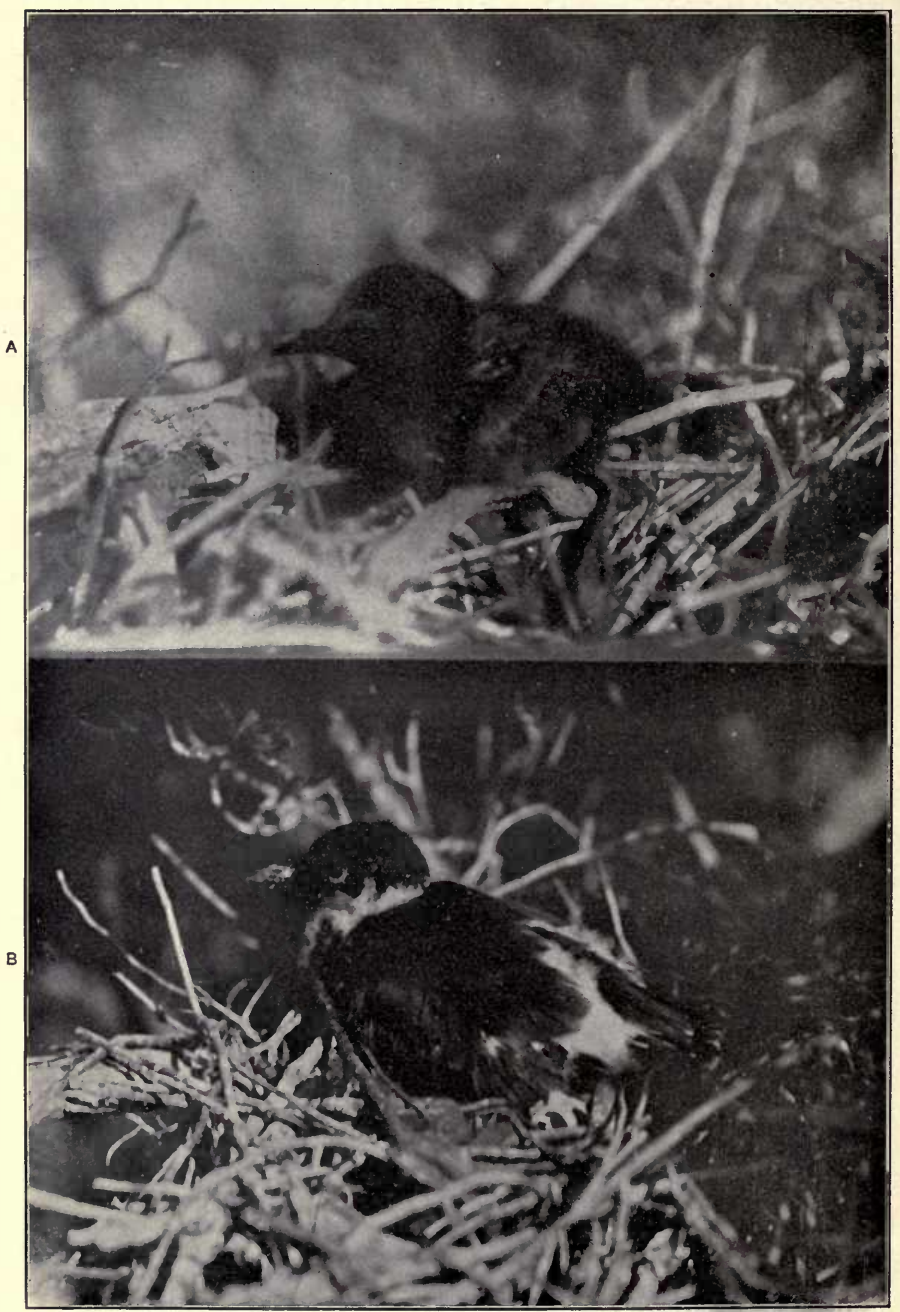

A, Young Noddy, Probably a Week Old; B, Bird Approximately 18 Days OLD.

Note development that has taken place in the interim. 


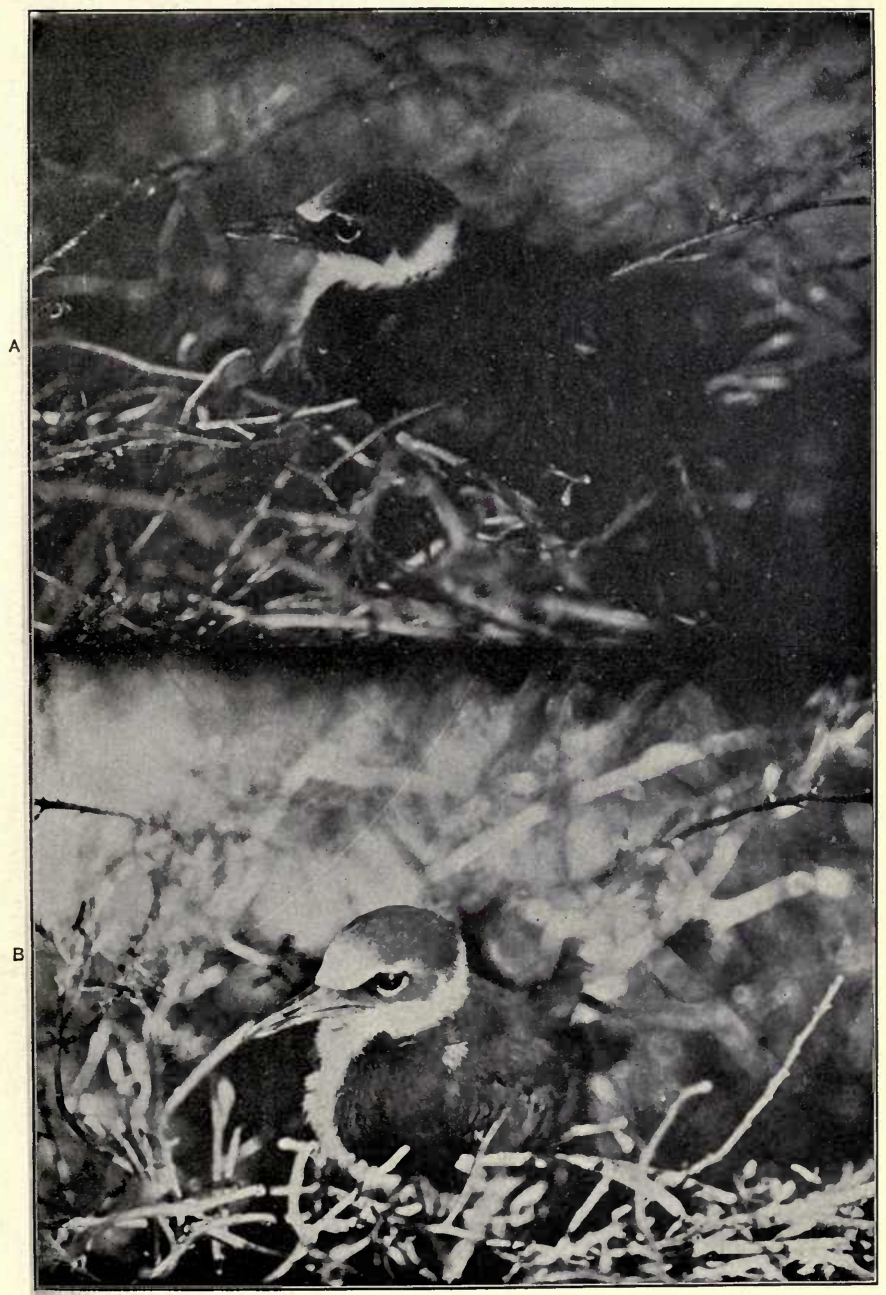

A, Noddy ABOUt 22 DAYS OLD; B, Noddy ABOUt 28 DAYS OLD. Note progress made in growth and feathering. 


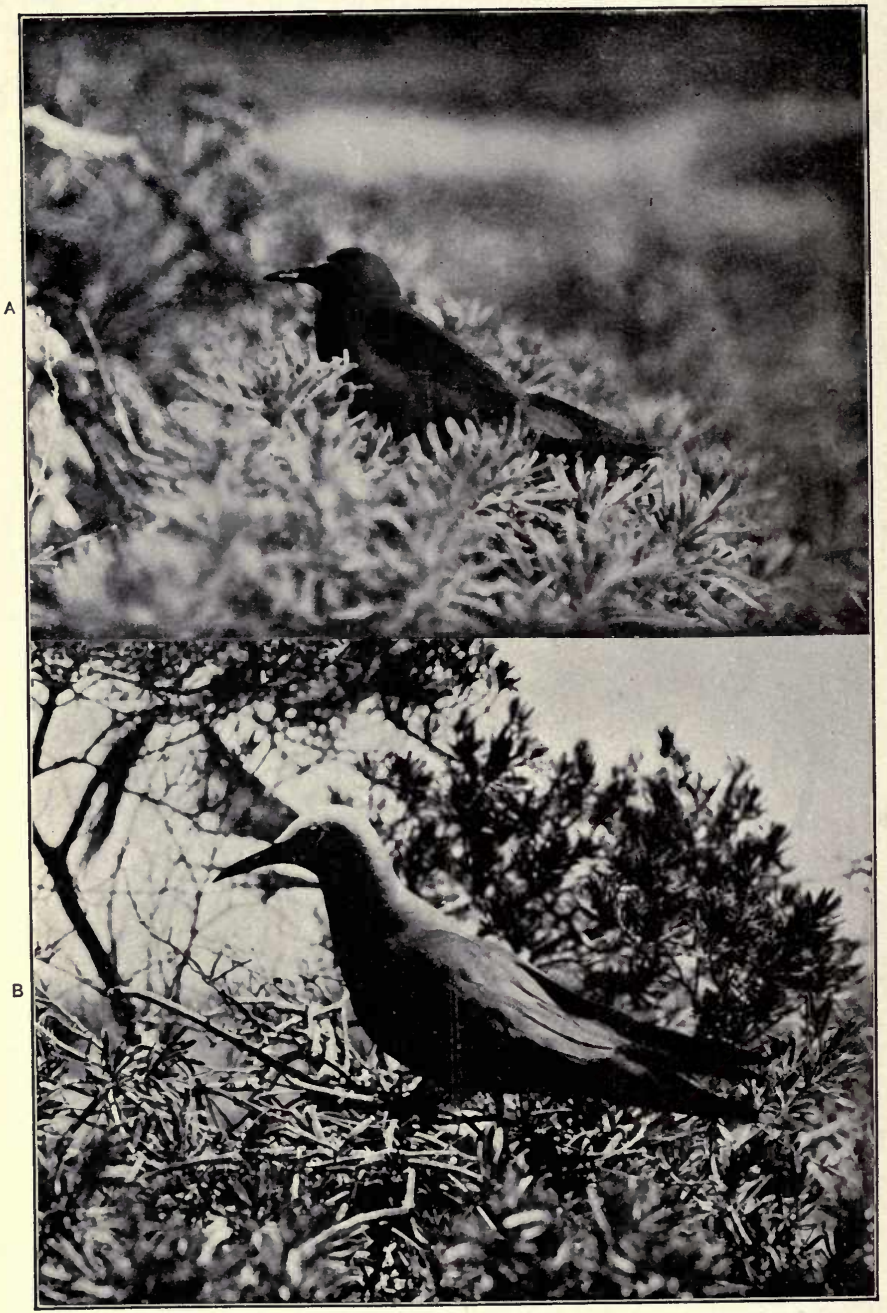

A, Noddy TERn About 40 Days Old; B, Adult Bird.

Note difference between fledged bird and parent at the time the young begin to fly. 


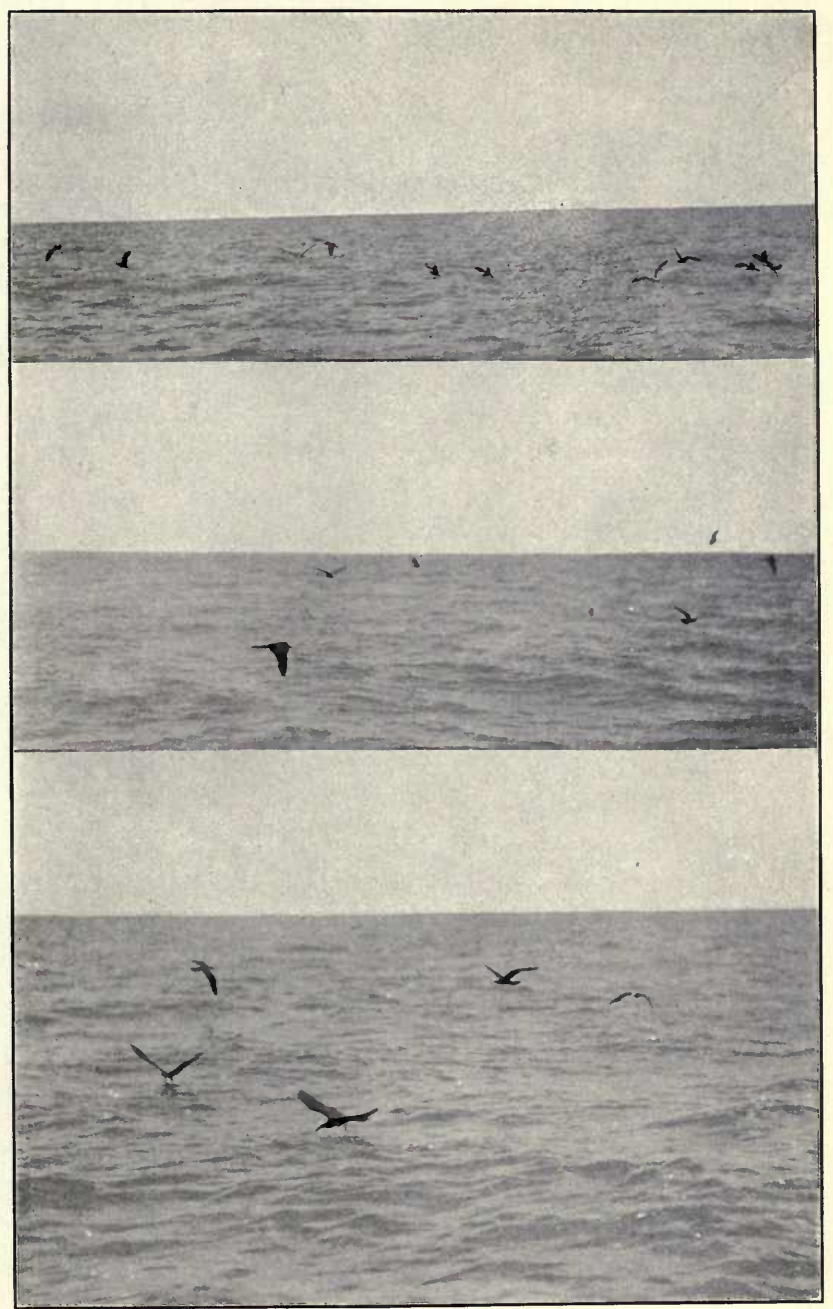

Group of NODDY TERNS FISHING; FOLLOWING A SCHOOL OF JUMPING MINNOWS. 


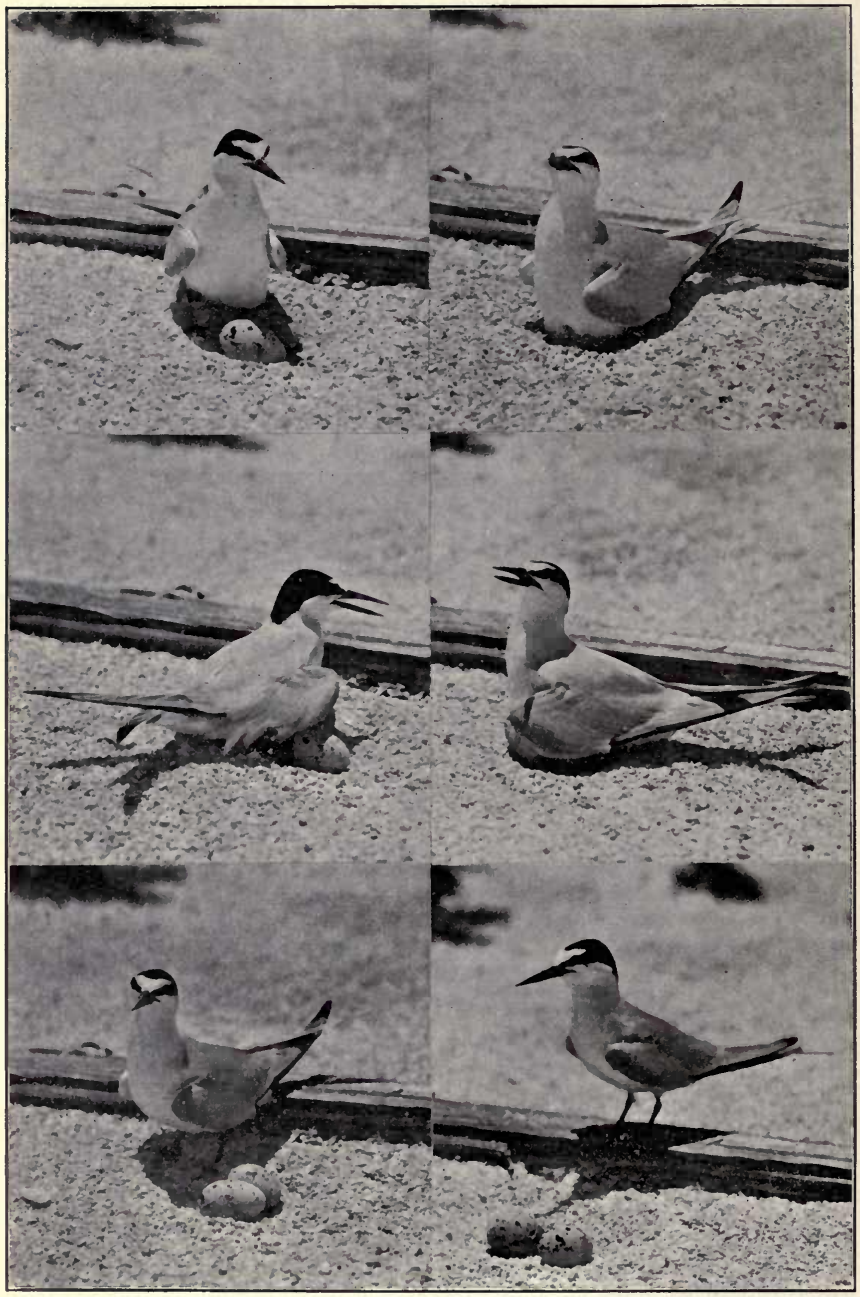

A Least Tern, her nest and Eggs, South End of loggerhead Key, 1916. 


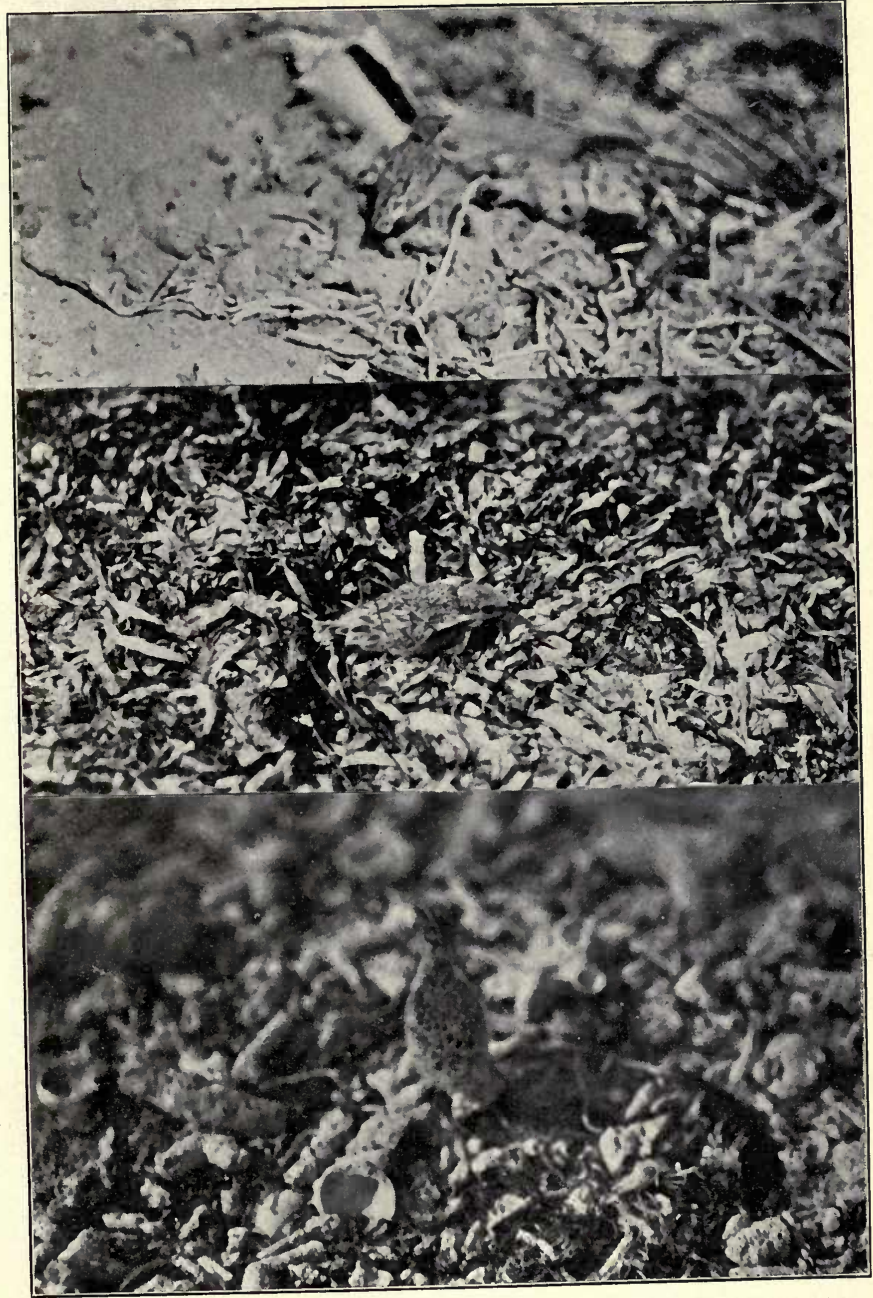

THREE YOUNG LEAST TERNS FROM COLONY ON SOUTH END OF LONG KEY, Showing DeVElopmental Stages and PRotective Coloration. 


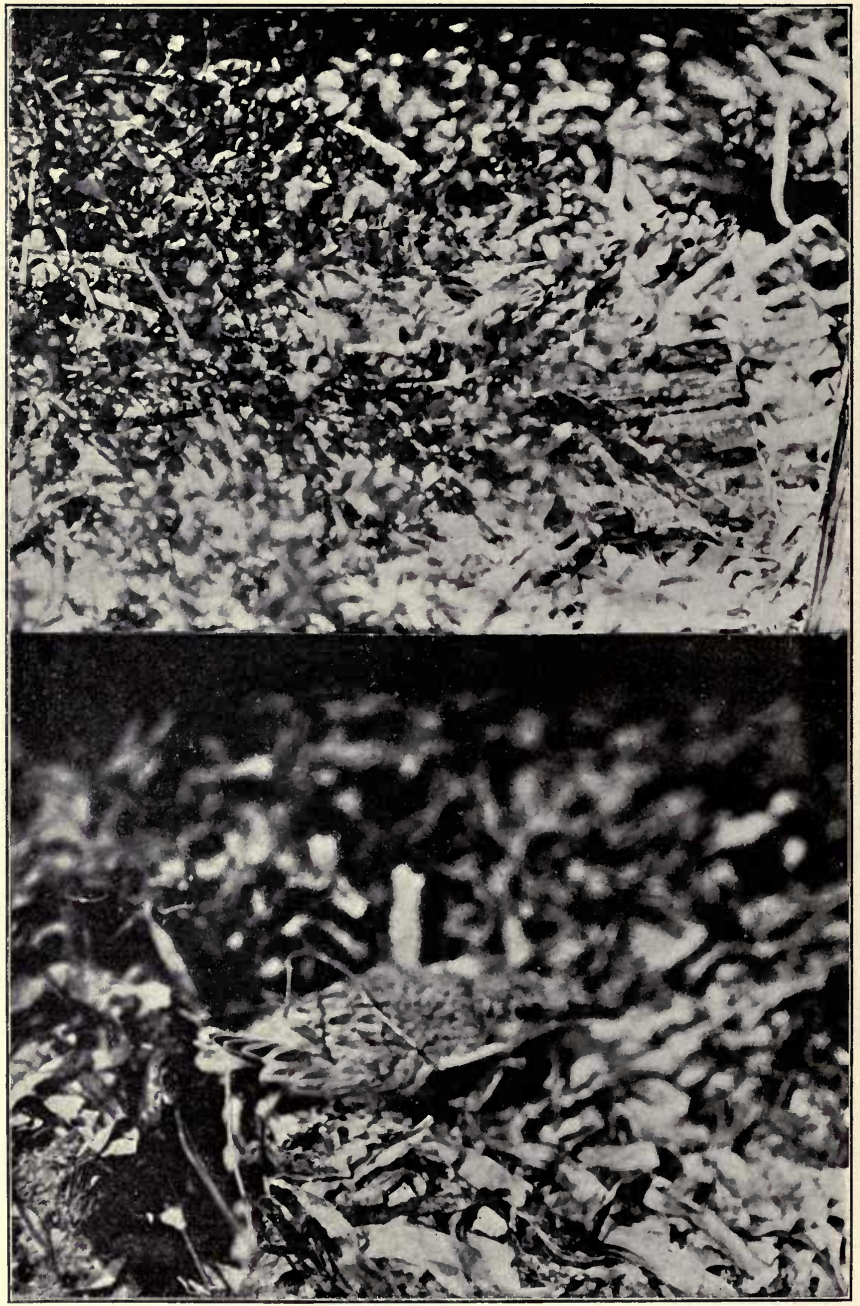

Two Views of Young Least Terns Illustrating Protective COLORATION.

In the upper picture the bird is flattened against fl otsam of the high tide line. The eye, a little to the left of the median line, will give a cue to the rest of the body. 


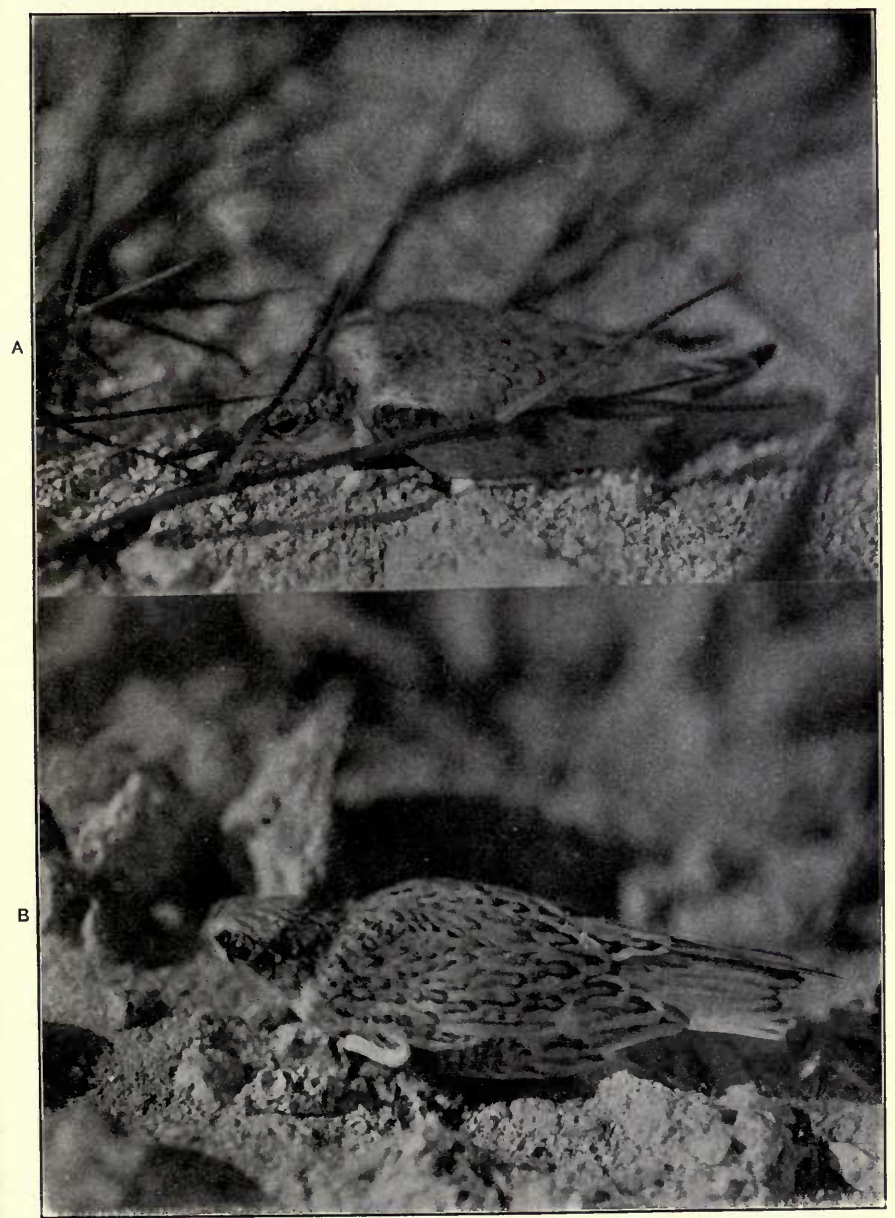

YOUNG LEAST TERNS.

A, Able to fly for a short distance; B, with wing clipped off by ghost crab. 


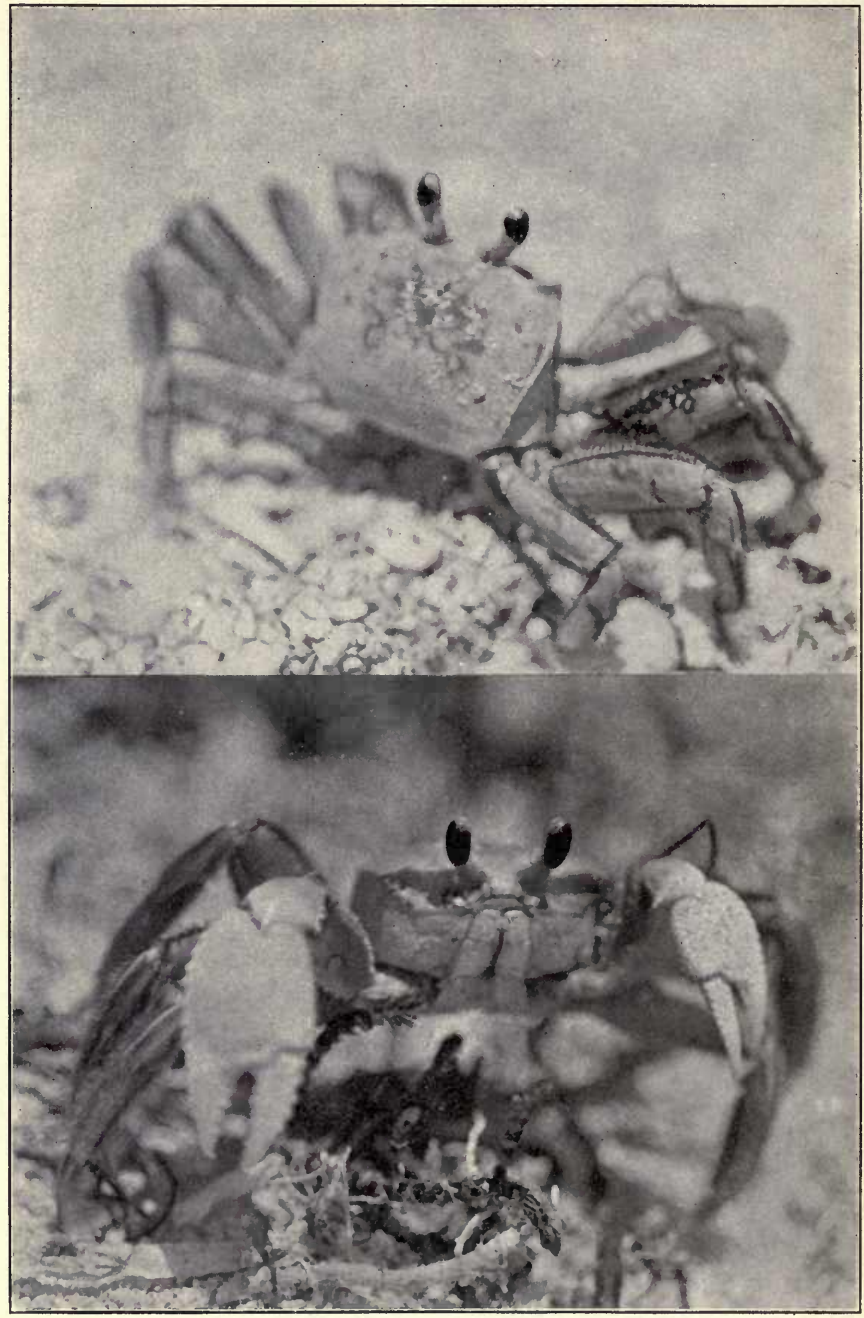

Ghost Crab (Ocypode albicans Bosc), One of the Destructive Agencies on THE TERN ROOKERIES. 


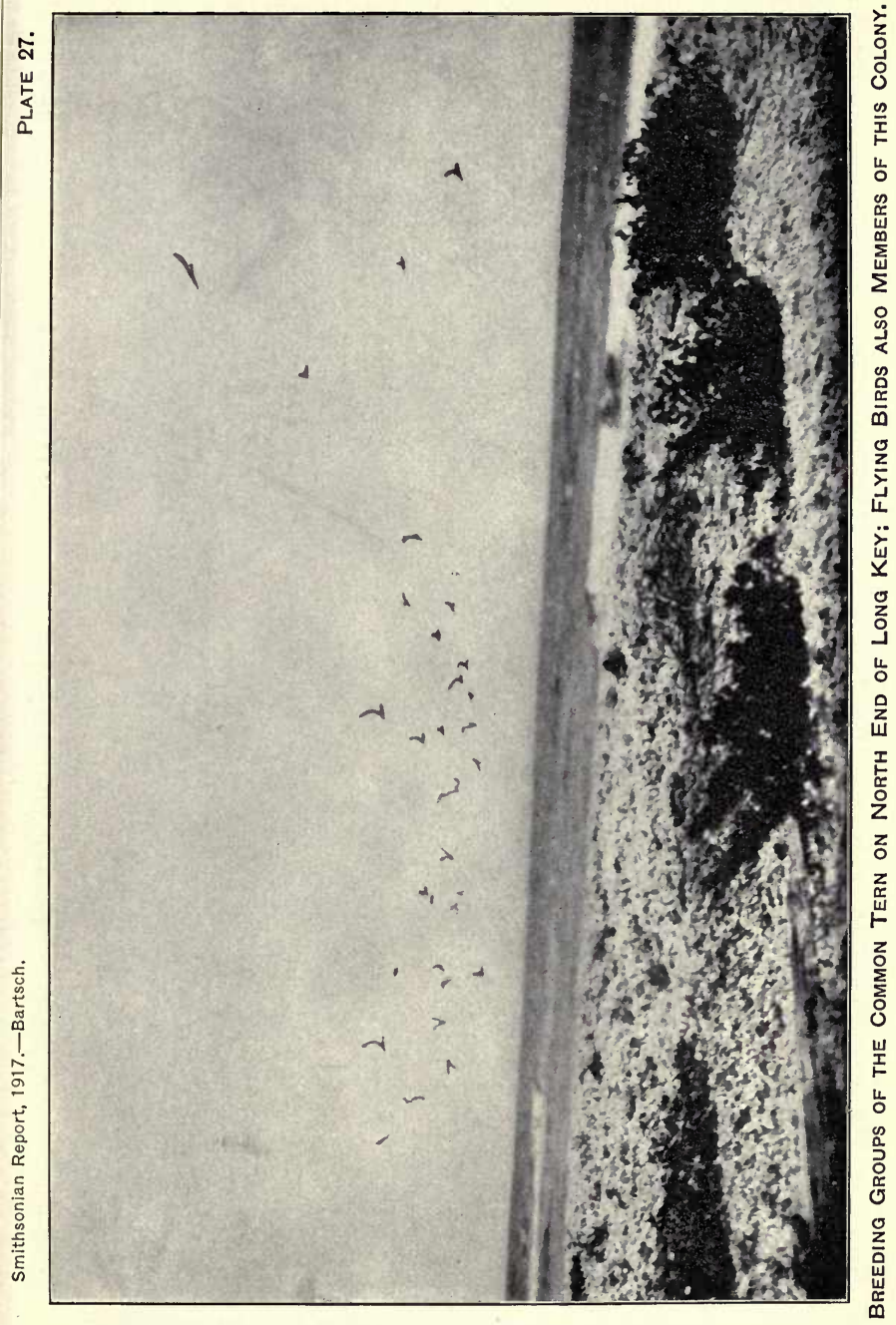




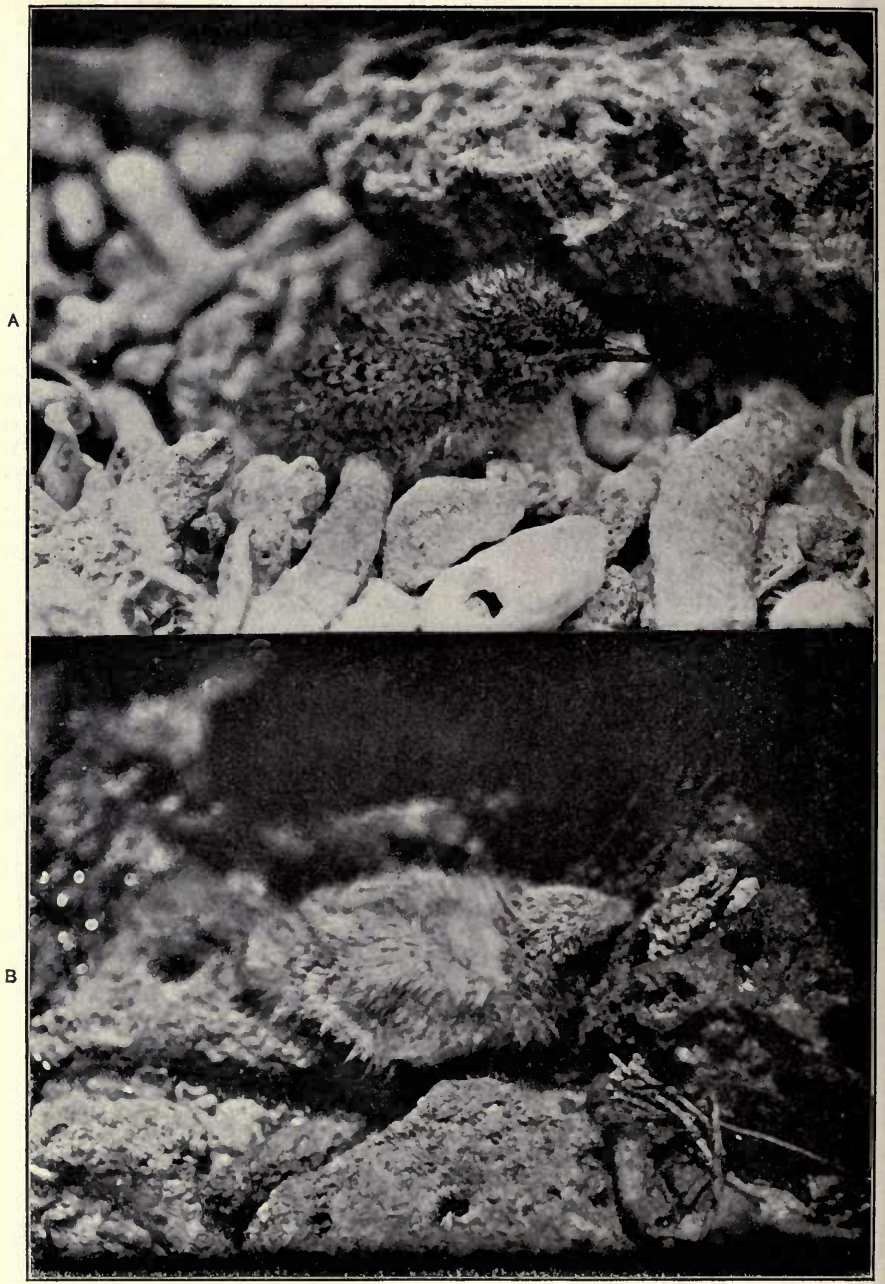

Young Common terns. A, About 5 Days Old; B, About 10 Days Old. 


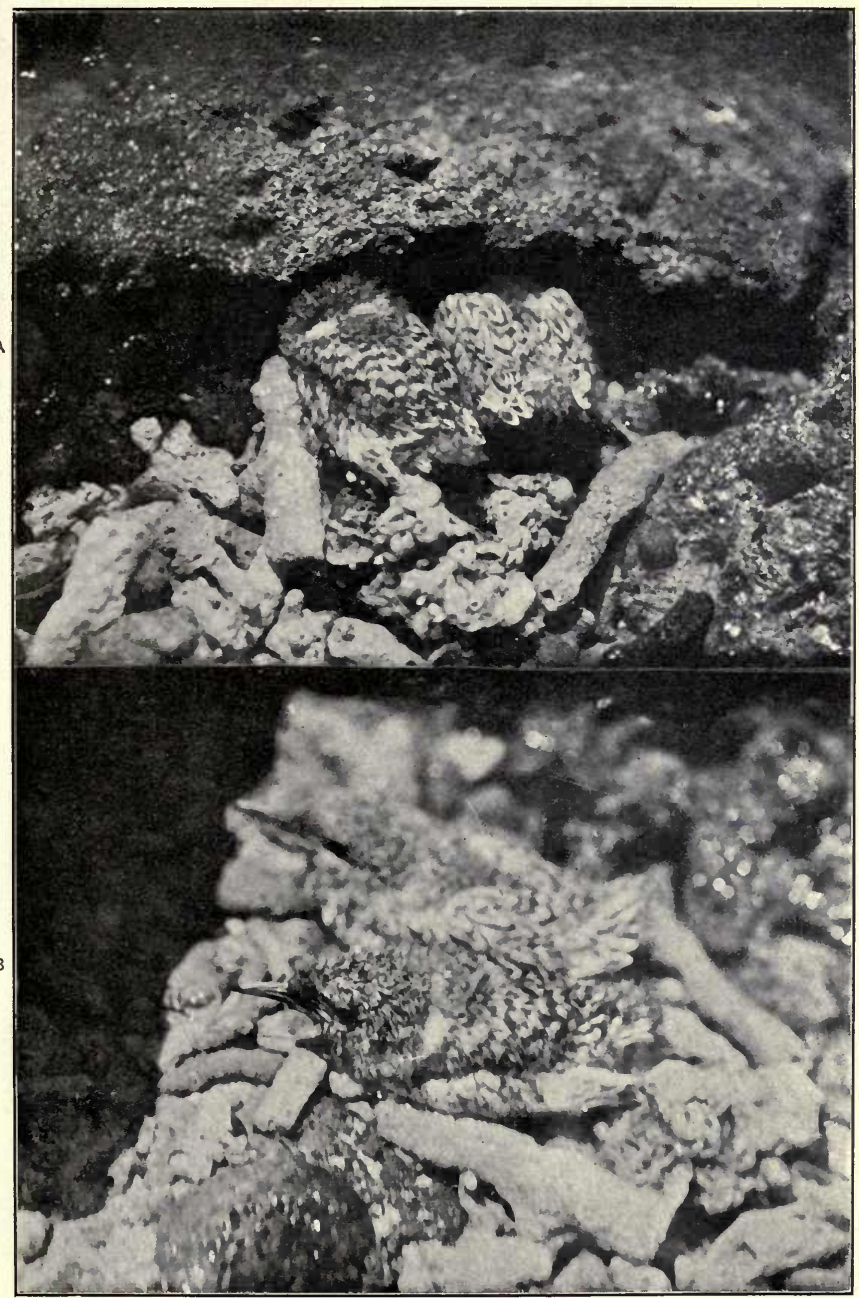

A. Two Young Common terns hiding Under a dead Coral Block. B. THE SAME BIRDS WITH THE BLOCK REMOVED.

They are probably 8 and 12 days old, respectively. 


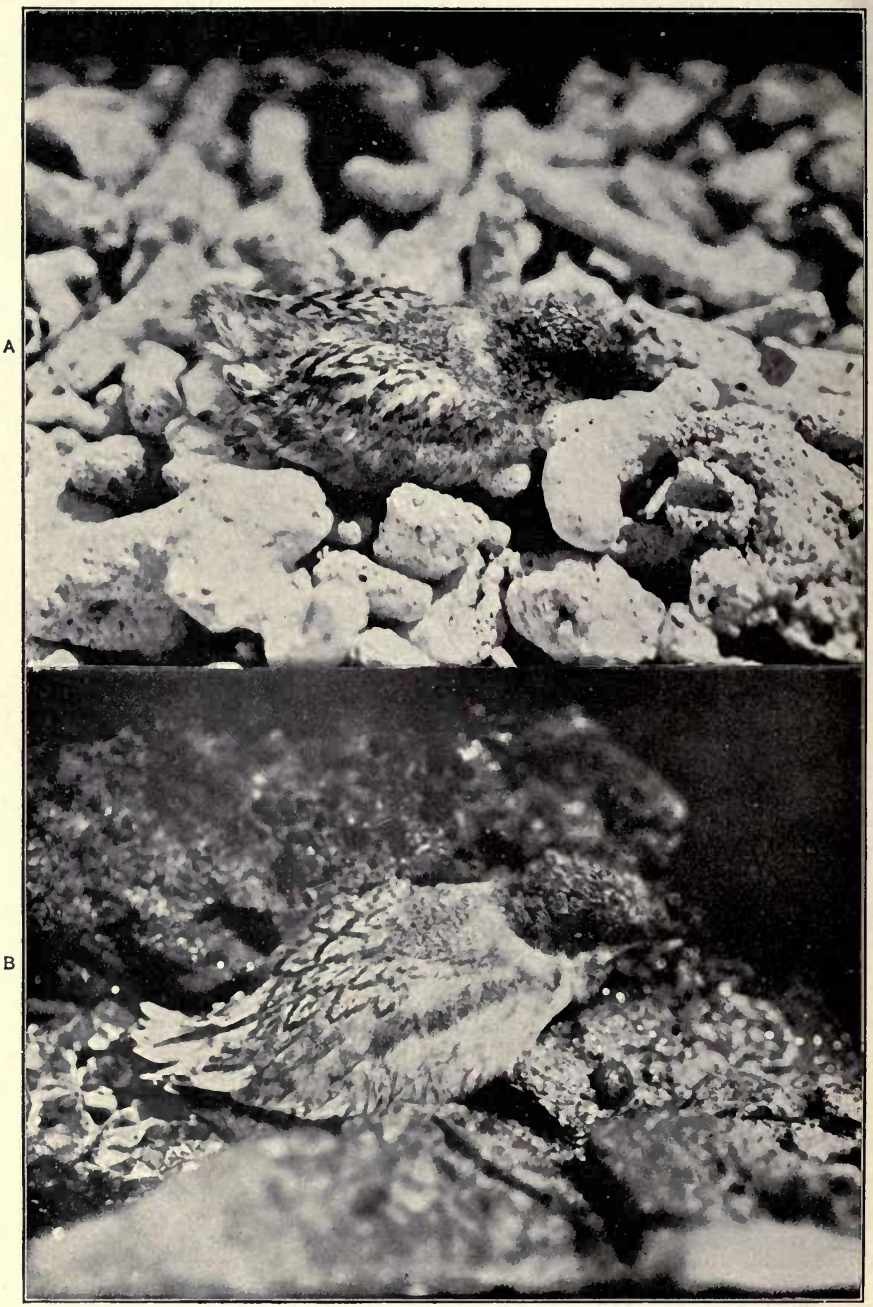

Young Common terns. A, About 2 Weeks Old; B, About 3 Weeks Old. 


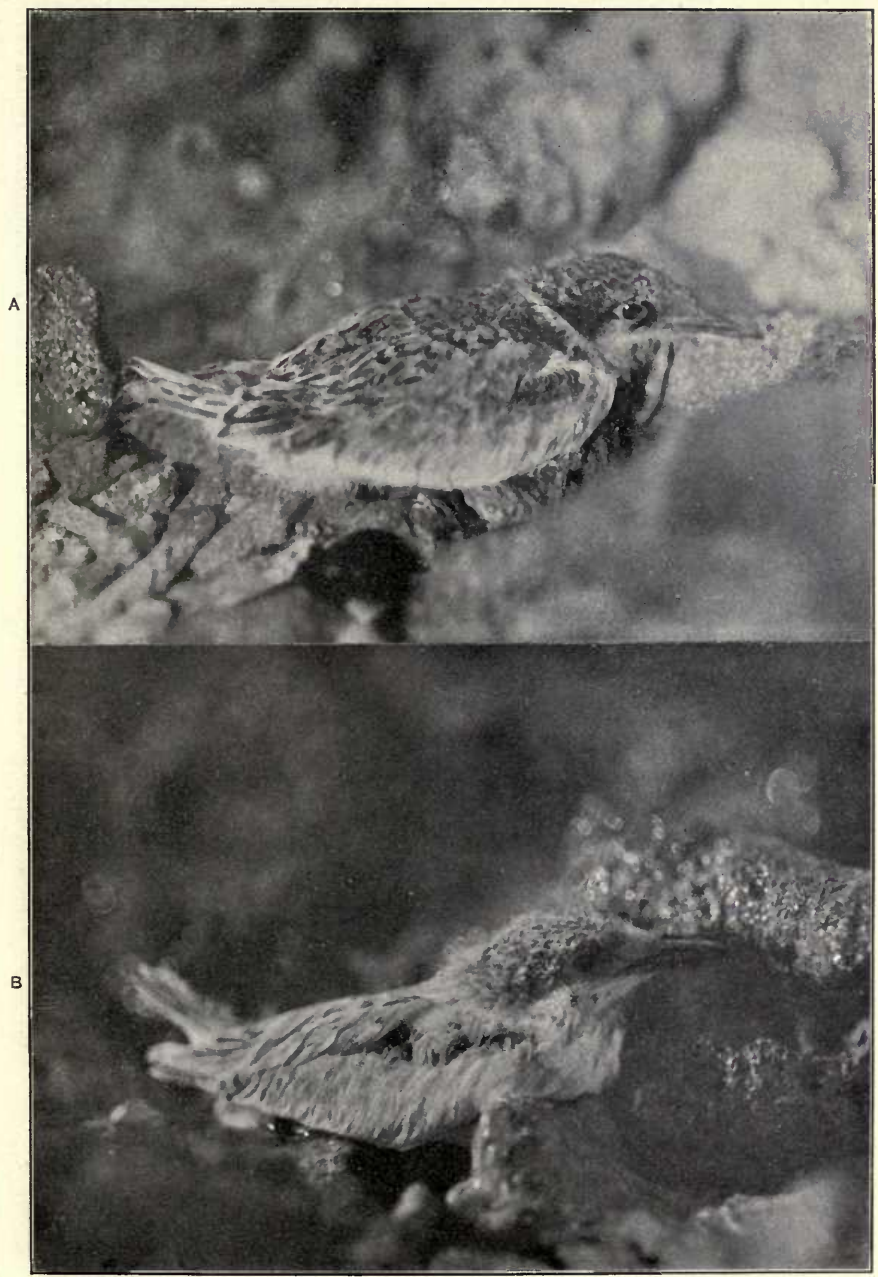

Young Common terns. A, ABout 28 Days Old; B, Almost Ready to Fly. 


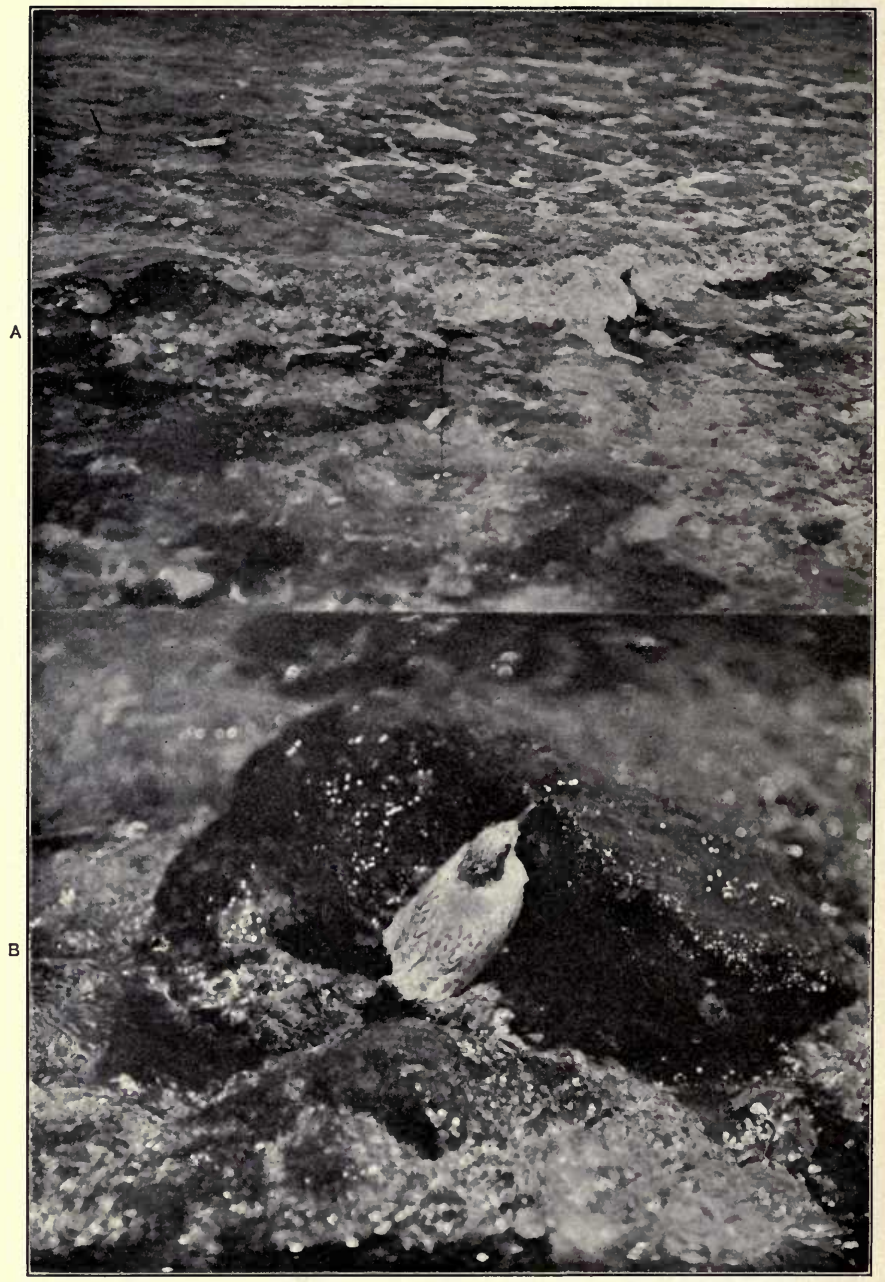

A. Youna Common Terns SWimmina OfF SHore. B. Youna Bird SWimmina AWAY FROM SHORE. 


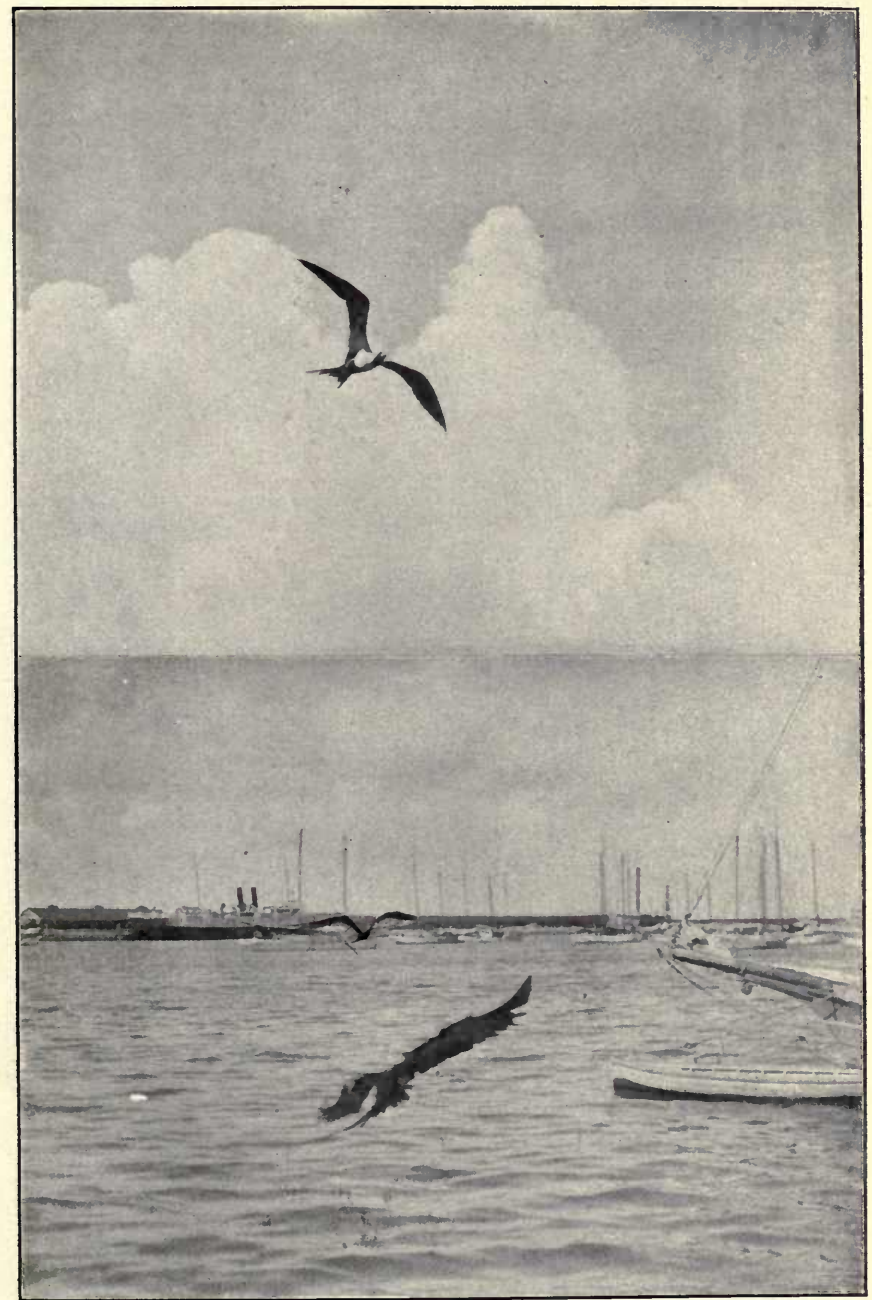

MAN-O'-WAR BIRDS HUNTING IN KEY WEST HARBOR. 


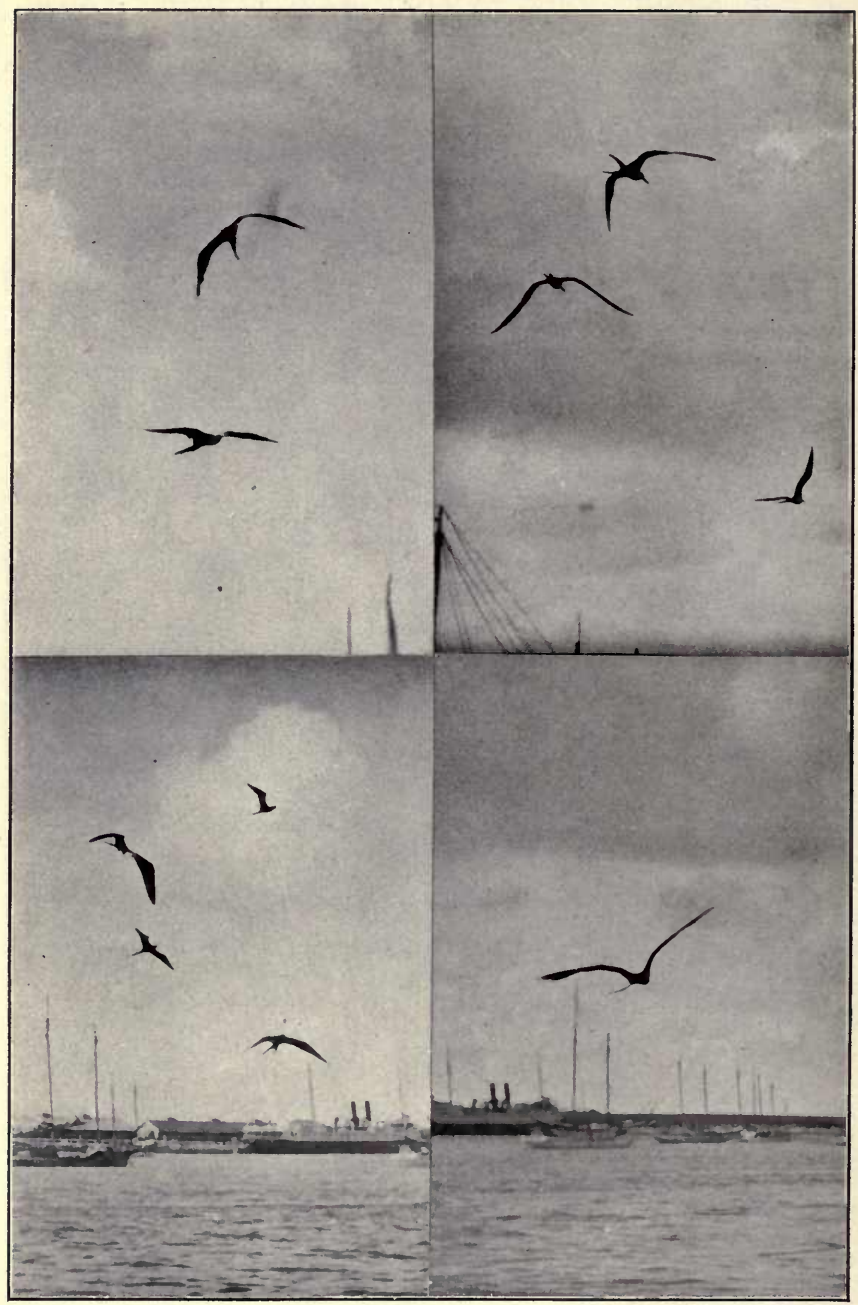

Instantaneous Photographs Showing Characteristic Poses of the MAN-O'-WAR BIRD ON WING, KEY WEST HARBOR. 


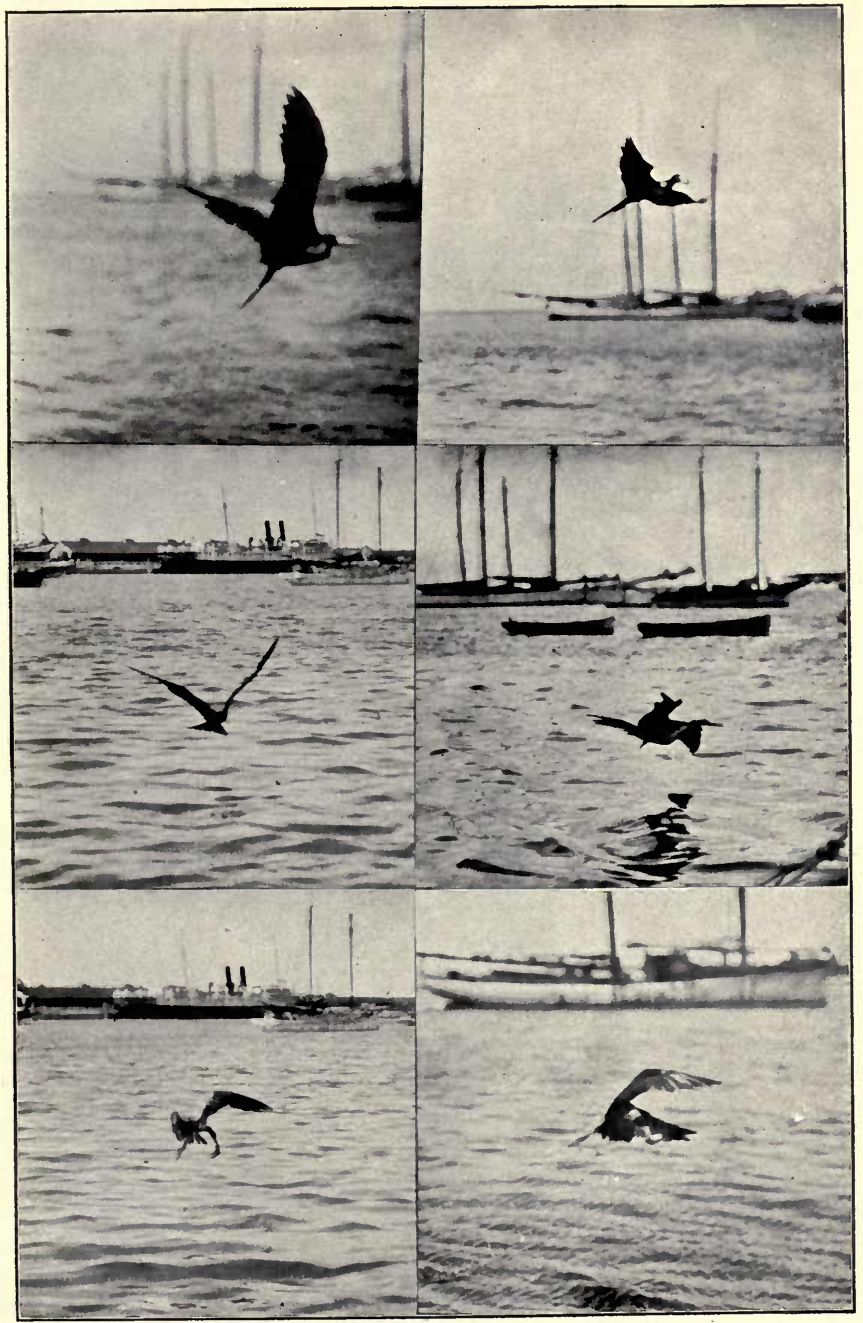

MAN-O'-WAR BIRDS FISHING IN KEY WEST HARBOR. 


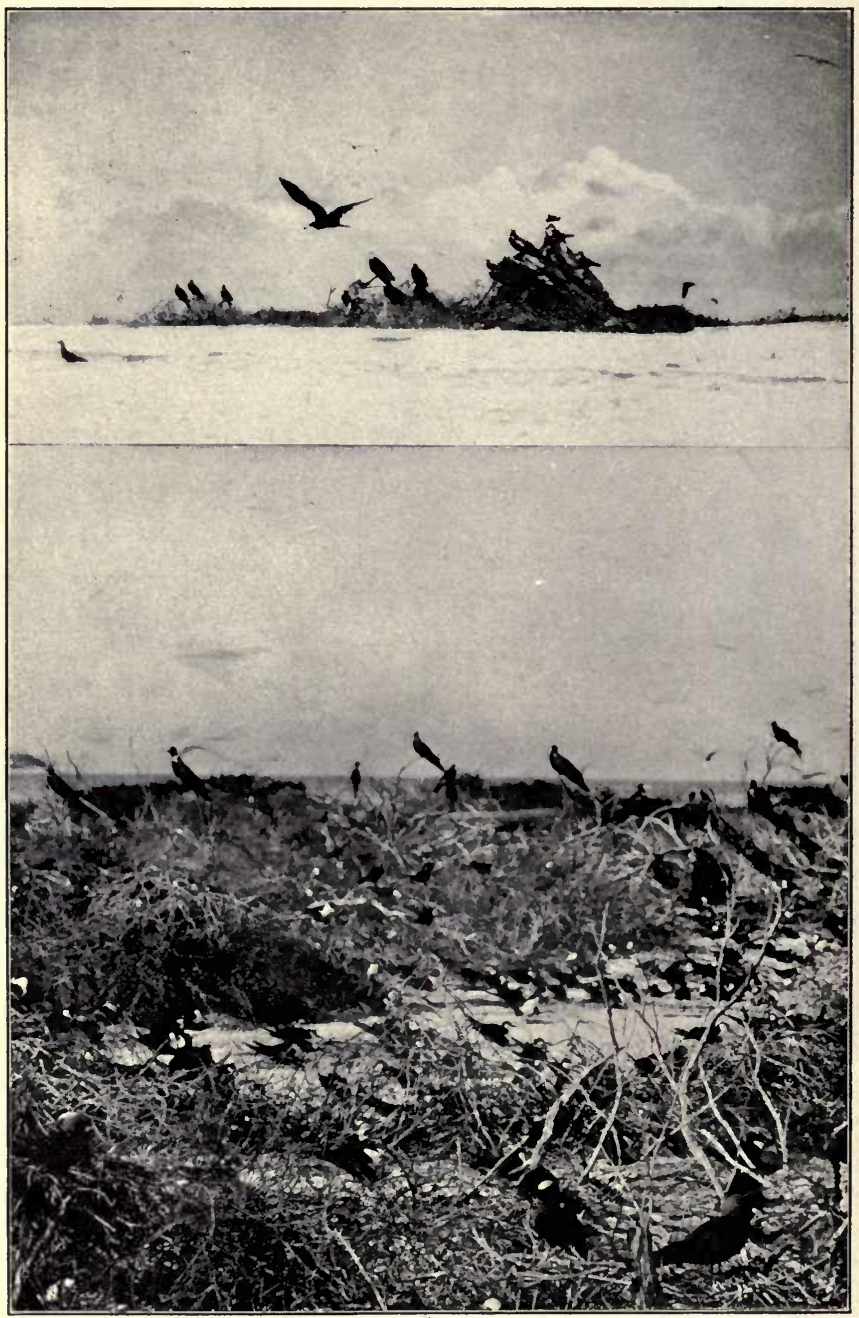

Shore Line of Bird Key, Showing Great Number of MAN-O'-WAR Birds. 


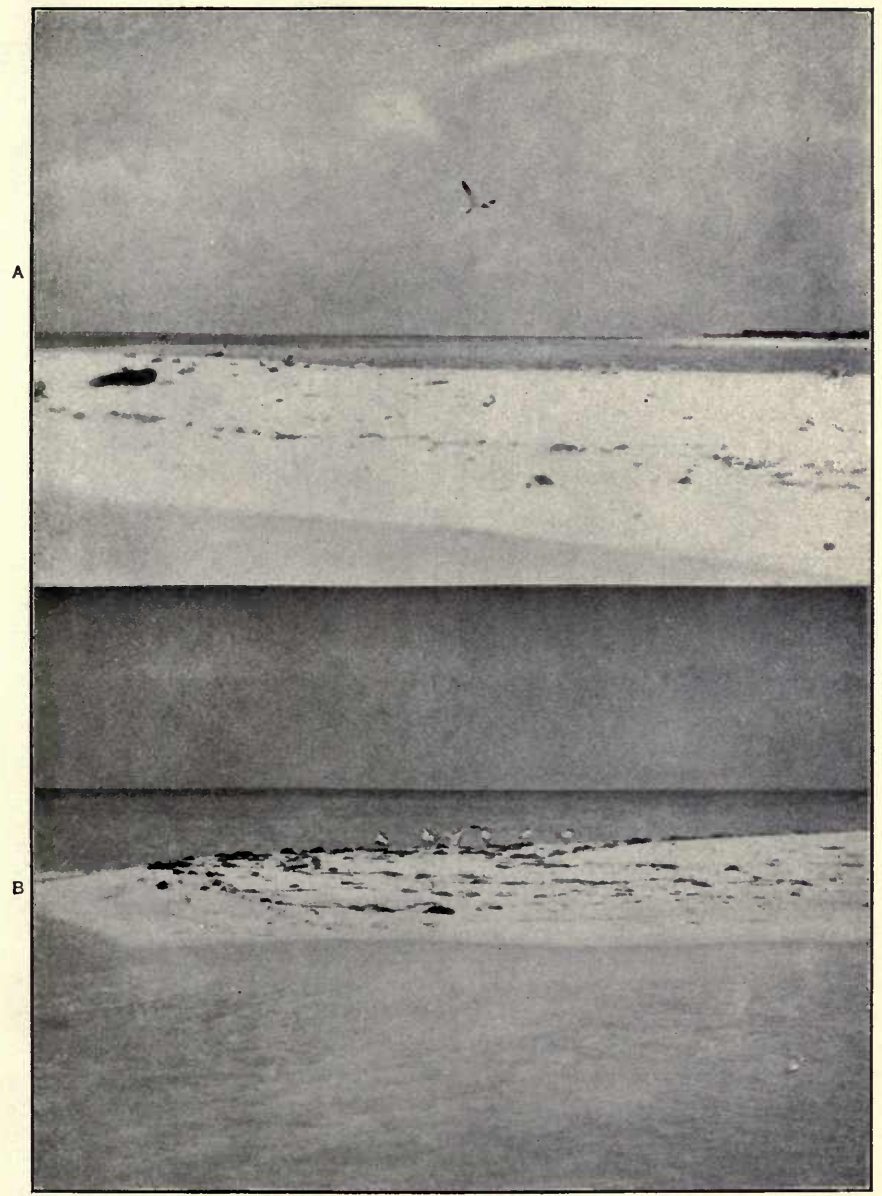

A. Pair of laughing Gulls on the northeast end of long Key. B. ROYAL TERNS SUNNING ON THE SANDSPIT, NORTH END OF LOGGERHEAD KEY. 


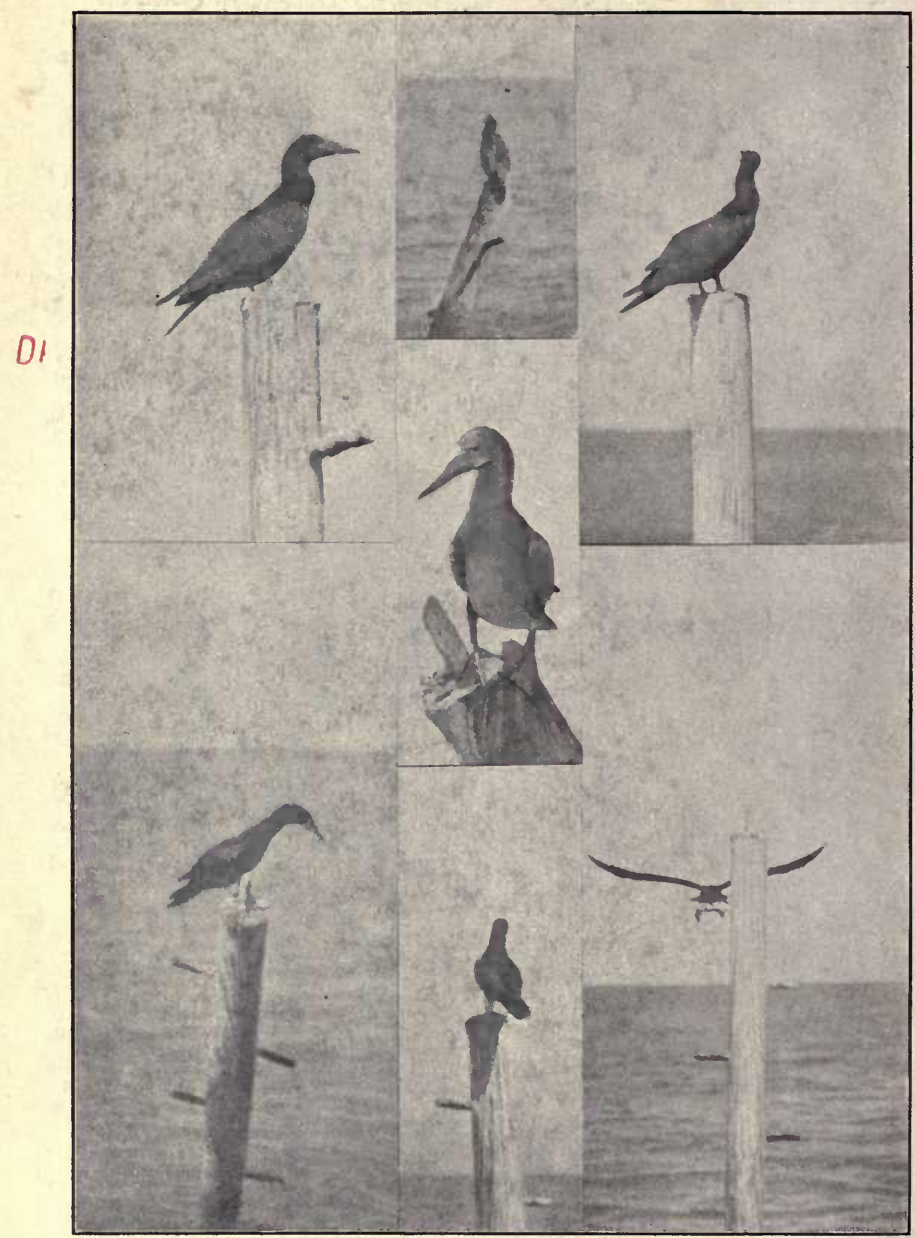

BOOBYS PHOTOGRAPHEd OFF BIRD KEY, TORTUGAS. 


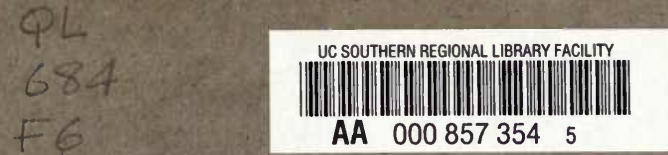




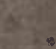

